\title{
EL REGLAMENTO BRUSELAS II TER Y EL RECURSO A LOS MASC EN MATERIA DE RESPONSABILIDAD PARENTAL Y SUSTRACCIÓN INTERNACIONAL DE MENORES
}

\author{
BRUSSELS II TER REGULATION AND THE PROMOTION \\ OF ADR IN MATTERS OF PARENTAL RESPONSIBILITY \\ AND INTERNATIONAL CHILD ABDUCTION
}

\author{
Prof. Dr. Carlos Esplugues Mota \\ Catedrático de Derecho internacional privado \\ Universidad de Valencia
}

Recibido: 22.04.2021 / Aceptado: 10.05.2021

DOI: https://doi.org/10.20318/cdt.2021.6253

\begin{abstract}
Resumen: El Reglamento Bruselas II ter supone un paso más en el proceso del fomento de la mediación y de otros medios de resolución alternativa de conflictos en el seno de la UE. A partir de este dato positivo, el Reglamento plantea una pluralidad de interrogantes. Ciertamente, las soluciones diseñadas incorporan un tratamiento innovador, y positivo. Sin embargo, la consolidación de una categoría autónoma de "acuerdos", independiente de los documentos públicos, y que va más allá de los concluidos en el marco estricto de un procedimiento de mediación, suscita directamente la cuestión de su concreción y entendimiento, y de su virtualidad. Planteando dudas adicionales sobre su propia filosofía y sobre su engarce en el modelo europeo de DIPr.

Palabras clave: Reglamento Bruselas II ter, acuerdo de mediación, sustracción internacional de menores, MASC, reconocimiento y ejecución.

Abstract: The Brussels II ter Regulation constitutes a further step in the process of the promotion of mediation and other ADR tools in the EU. Standing on this positive element, the Regulation raises a plurality of issues of different nature and relevance. The solutions designed are innovative and positive. However, the establishment of an autonomous category of "agreements", independent of public documents, and which embody agreements reached within and outside mediation proceedings, directly raises the issue of its concretion and understanding, and of its virtuality. In addition to that, it generates certain doubts as regards its rationale and its link with the European system of PIL.
\end{abstract}

Keywords: Brussels II ter Regulation, ADR, international legal kidnapping, settlement, recognition and enforcement.

Sumario: Hacia la consolidación de un nuevo entendimiento del derecho de acceso a la justicia, también en relación con la responsabilidad parental y la sustracción de menores. II. La constatación de un amplio apoyo a la mediación como forma de resolver -y prevenir- las situaciones de sustracción de menores. 1. El Consejo de Europa. 2. La Conferencia de La Haya de DIPr. 3. La situación española. III. El fomento de la mediación en, y por, la Unión Europea. 1. La Directiva 2008/52/CE como clave de bóveda del modelo europeo de mediación en materia civil y mercantil. A) Una transposición con claroscuros. B) La limitada circulación en el seno de la UE de los acuerdos alcanzados en el marco de una mediación. IV. Los Reglamentos Bruselas II bis y ter y el recurso a la mediación y otras formas de resolución amistosa de litigios. 1. El Reglamento Bruselas II bis. 2. El Reglamento Bruselas II ter. A) El contenido del acuerdo en materia de responsabilidad parental. 
B) La posibilidad de prórroga del foro con respecto a la homologación del acuerdo alcanzado. C) La eficacia del acuerdo alcanzado en la UE y su circulación en el seno de la UE. a) Resoluciones judiciales, documentos públicos y acuerdos. b) Reconocimiento y, en su caso, ejecución de acuerdos en materia de responsabilidad parental y sustracción internacional de menores. D) La audiencia del menor como novedad del Reglamento Bruselas II ter y su salvaguarda en relación con la eficacia de los acuerdos alcanzados por las partes en relación con la responsabilidad parental y la sustracción de menores. V. Qué será, será (Whatever will be, will be).

\section{Hacia la consolidación de un nuevo entendimiento del derecho de acceso a la justicia, también en relación con la responsabilidad parental y la sustracción de menores}

1. Si algo caracteriza a la justicia en las décadas recientes es la doble imagen de crisis y de búsqueda de alternativas. Unas ideas que se ven reflejadas en la existencia de una creciente percepción de la justicia estatal como incapaz de aportar respuestas adecuadas, previsibles, rápidas y accesibles a los ciudadanos, miembros de unas sociedades crecientemente conflictivas y conflictuadas ${ }^{1}$. Ello alimenta un aumento paulatino de la insatisfacción respecto de los tribunales estatales que, entre otros resultados, facilita el afianzamiento de una tendencia global en favor del recurso a los denominados medios alternativos de resolución de controversias (MASC) ${ }^{2}$.

2. Mecanismos que, con el transcurso del tiempo, han pasado de presentarse como meras posibilidades teóricas previstas con más o menos amplitud, y elaboración, en los distintos ordenamientos jurídicos, a convertirse en opciones reales, con vistas a lograr la resolución de sus disputas por parte de los ciudadanos ${ }^{3}$. Hasta el punto de que transmutarse hoy en auténticos medios complementarios a la justicia estatal, a los que el ciudadano puede, y debe, acceder en condiciones de igualdad con ésta ${ }^{4}$. Favoreciendo, por ende, la consolidación de una nueva y polimorfa noción de "acceso a la justicia"s.

3. Dentro de la exploración de vías complementarias a los tribunales de justicia como forma de arraigar este nuevo paradigma de justicia ${ }^{6}$, la mediación cuenta con una enorme trascendencia particular, adquirida con especial énfasis en los últimos años, al compás de la crisis del arbitraje comercial internacional ${ }^{7}$. Convirtiéndose, de hecho, en la "estrella emergente" del firmamento de los MASC.

4. Esta búsqueda de alternativas a una justicia estatal cada vez más lenta, e incierta e insatisfactoria en el resultado se hace patente en los más diversos ámbitos y, también, en el complejo sector de

${ }^{1}$ Vid. C. Esplugues Mota, "El arbitraje comercial internacional en Iberoamérica: una realidad consolidada no exenta de tensiones", en C. Esplugues Мота (Ed.), Tratado de arbitraje comercial interno e internacional en Iberoamérica, Valencia, Tirant lo Blanch, 2019, pp. 49-53.

${ }^{2} \mathrm{Al}$ respecto, y por todos, considérese S. BArona y C. Esplugues, “ADR Mechanisms and Their Incorporation into Global Justice in the Twenty-First Century: Some Concepts and Trends", en C. Esplugues y S. BARONa (Eds.), Global Perspectives on $A D R$, , Cambridge, intersentia, 2014, pp. 7-16.

${ }^{3}$ Nótese S. Barona Vilar, Mediación civil en asuntos civiles y mercantiles en España. Tras la aprobación de la Ley 5/2012, de 6 de julio, Valencia, Tirant lo Blanch, 2013, pp. 19-20.

${ }^{4}$ C. Esplugues Mota, Mediación civil y comercial. Regulación internacional e iberoamericana,Valencia, Tirant lo Blanch, 2019, pp. 16-22.

${ }^{5} \mathrm{Al}$ respecto, vid. C. Esplugues Mota, "Cruzando el espejo arbitral: las propuestas de la CNUDMI en materia de arbitraje acelerado y la búsqueda del "triángulo mágico"', en S. BARONA VILAR (Ed.), Psicoanálisis del arbitraje: solución o problema en el actual paradigma de justicia, Valencia, Tirant lo Blanch, 2020, pp. 79-81; C. Esplugues Mota, "El arbitraje comercial internacional", cit., pp. 53-57.

${ }^{6}$ Vid. S. Barona Vilar, “'Justicia integral' y 'access to justice', crisis y evolución del 'paradigma”, en S. Barona VILAR (Ed.), Mediación, arbitraje y jurisdicción en el actual paradigma de justicia, Cizur Menor, Civitas Thomson Reuters, 2016, p. 45 y ss.

${ }^{7}$ Vid. S. Barona Vilar, "Psicoanálisis del arbitraje en la sociedad virtual y líquida del Siglo XXI. Entre la deconstrucción y la caquexia”, en S. Barona VILAR (Ed.), Psicoanálisis del arbitraje, cit., p. 43 y ss.

${ }^{8} \mathrm{~S}$. Barona VILAR, Nociones y principios de las ADR (Solución extrajurisdiccional de conflictos), Valencia, Tirant lo Blanch, 2018, pp. 21-27. 
la sustracción internacionales de menores". Una realidad convertida en "problema social globalizado"10 que viene caracterizada por la conjunción - e interacción, en muchas ocasiones centrífuga- de distintos factores dotados de autonomía y lógica propia. Situaciones en las que, en primer lugar, y entre otros, existe un menor, sujeto de derechos propios, y diferenciados del resto de los miembros de la familia y de la familia en sí misma ${ }^{11}$-con independencia de la forma de organización familiar de que se trate ${ }^{12}$-, que por sus propias características personales y jurídicas presenta una situación de especial fragilidad y vulnerabilidad, dependiendo de los adultos para su crecimiento y desarrollo. Un menor al que el posible traslado ilícito, y la consiguiente abrupta separación de su entorno vital que ello implica, puede generar un impacto psicológico enorme ${ }^{13}$, por lo que se requiere de una especial salvaguarda de sus intereses y expectativas a través de la articulación de respuestas singulares ${ }^{14}$.

5. Se hace igualmente patente, en segundo lugar, la presencia de unos derechos de custodia $\mathrm{y}$ visita que se han visto violados, y que deben de intentar restituirse de forma inmediata ${ }^{15}$, máxime atendiendo al impacto que el transcurso del tiempo puede tener en el menor ${ }^{16}$. Así como, también, en tercer lugar, se patentiza la consolidación del principio del interés superior del menor, merecedor de una "consideración primordial" en el sentido de que "no puede estar al mismo nivel que todas las demás consideraciones" ${ }^{17}$. Y que, como reconoce la Observación General no 14 (2013) del Comité de los Derechos del niño ${ }^{18}$, se conforma como premisa, objetivo y guía interpretativa -"un derecho, un principio y una norma de procedimiento" 19 - de toda la normativa y de todas las situaciones que involucran a éste ${ }^{20}$.

\footnotetext{
${ }^{9}$ Nótese, Y. Velarde D'Amil, “La mediación en los supuestos de sustracción internacional de menores y el Convenio de La Haya de 25 de octubre de 1980, sobre los aspectos civiles de la sustracción internacional de menores", Revista de Derecho UNED, $\mathrm{n}^{\circ} .17,2015$, pp. 1280-1282.

${ }^{10}$ A. HernÁndez RodríGuez, "Mediación y secuestro internacional de menores: ventajas e inconvenientes", $C d T$, vol. 6, $\mathrm{n}^{\circ}$ 2, 2014, p. 131. Igualmente, M. GonZÁLEZ MARIMÓn, "La libre circulación de resoluciones judiciales en la UE en el caso de la sustracción internacional de menores", Revista Justicia y Derecho, vol. 3, n 2, 2020, p. 2.

${ }^{11}$ Nótese A. BorRás, "La evolución de la protección del niño en el Derecho internacional privado desde el Convenio de Nueva York de 1989”, en F. Aldecoa Luzárraga y J.J. Forner Delaygua (Dirs.), La Protección de los niños en el Derecho Internacional y en las relaciones internacionales. Jornadas en conmemoración del 50 aniversario de la Declaración Universal de los Derechos del Niño y del 20 aniversario del Convenio de Nueva York sobre los Derechos del Niño, Madrid, Marcial Pons, 2010, pp. 12-14.

${ }^{12}$ C. Valdebenito Larenas, A. Rojo Burrows y P. Campillay Díaz, "Mediación familiar y plan de parentalidad: mecanismos para el ejercicio del cuidado personal y corresponsabilidad en la paternidad y maternidad activa", Revista de Mediación, $\mathrm{n}^{\mathrm{o}} 12-2,2019$, p. 2.

${ }^{13}$ Nótese, Service Social International, Resolver los conflictos familiares. Una guía para la mediación familiar internacional, Ginebra, SSI, 2015, pp. 66-68.

${ }^{14}$ M. González Marimón, Menor y responsabilidad parental en la Unión Europea, Valencia, Tirant lo Blanch, 2021, p. 64 y ss.; M. JÄNTERÄ-JAREBORG, "The Child in the Intersections between Society, Family, Faith and Culture", en M. JÄNTERÄJareborg (Ed.), The Child's Interests in Conflict. The Intersections between Society, Family, Faith and Culture, Cambridge, intersentia, 2016, p. 1 y ss.; A. HeRnÁndez RodríGuez, "Mediación y secuestro internacional”, cit., pp. 131-132.

${ }^{15}$ Vid. M.A. Gandía Sellens, "La responsabilidad parental y la sustracción de menores en la Propuesta de Comisión para modificar el RB II Bis: algunos avances, retrocesos y ausencias”, AEDIPr, T. 17, 2017, p. 805.

${ }^{16}$ Considérese, M. GonzÁlez MARimón, "Un paso más en el proceso de armonización del derecho privado europeo: la concreción por el TJUE del concepto de residencia habitual del menor recogido en el Reglamento Bruselas II bis", Revista Boliviana de Derecho, $\mathrm{n}^{\circ} 30$, julio 2020, pp.480-482.

${ }_{17}$ Comité de LOS DEREChOS DEL NIÑo, Observación general $n^{\circ} 14$ (2013) Sobre el derecho del niño a que su interés superior sea una consideración primordial (artículo 3, párrafo 1), CRC/C/GC/14, 29.5.2013, p. 10, nº. 37. Nótese al respecto, S. QUICios Molina, "Filiación e interés superior del menor", en M.C. García Garnica y N. Marchal Escalona (Dirs.), Aproximación interdisciplinar a los retos actuales de protección de la infancia dentro y fuera de la familia, Cizur Menor, Thomson Reuters Aranzadi, 2019, pp. 44-48, quien gráficamente habla del principio como una "vara de medir", o A. FERNÁNDEZ PÉREZ, "El interés superior del menor: derecho fundamental y/o principio rector del Derecho internacional privado", en J.M. Velasco RetamOSA (Dir.), Menores extranjeros: problemas actuales y retos jurídicos, Valencia, Tirant lo Blanch, 2018, p. 34 y ss.

${ }^{18}$ Vid. nota supra.

${ }^{19}$ COMITÉ DE LOS DERECHOS DEL NIÑO, Observación general $n^{\circ} 14$, cit., p. 3.

${ }^{20}$ Sobre el concepto de "interés superior del menor" vid., por todos, M. GonZÁLEZ MARIMÓn, "El principio del interés superior en supuestos de sustracción ilícita internacional: la jurisprudencia del TJUE y TEDH", en M.C. GARCÍA GARNICA y N. Marchal Escalona (Dirs.), Aproximación interdisciplinar, cit., p. 643 y ss. Igualmente, nótese, COMITÉ DE LOS DERECHOS DEL NIÑo, Observación general $n^{\circ} 14$, cit., pp. 9-10.
} 
Todo ello modulado por el creciente impacto en este magma de intereses de realidades como pueda ser la violencia de género ${ }^{21}$.

6. A todo ello se une, como elemento de fondo, la presencia de un conjunto de ordenamientos jurídicos y autoridades de distintos países, susceptibles de verse vinculadas con estas situaciones y de las que se exige diligencia y rapidez, amén de una especial sensibilidad. A la vez que se constata la inexistencia de un marco jurídico normativo internacional unificado ${ }^{22}$.

7. La no siempre fácil conjunción de todos estos factores apuntados genera un volumen adicional de complejidad que no siempre resulta sencilla de resolver, y que incide plenamente en el objetivo de lograr la pronta restitución del menor desde el lugar en que se encuentra, al país desde el que fue ilícitamente trasladado. Ello tiene un efecto directo en el favorecimiento del recurso a los MASC con vistas a resolver la situación planteada, intentando asegurar, a su vez, que el menor vea satisfecho, en el futuro, su derecho a relacionarse con ambos progenitores, tanto con el titular del derecho de custodia, como con aquel que lo violó a través del logro de una solución duradera ${ }^{23}$.

8. En este sentido, si bien subsisten en Europa algunas posiciones poco partidarias del uso de la mediación en el sector de las disputas vinculadas con menores ${ }^{24}$, llegándose, incluso, a afirmarse que su uso en este ámbito resulta muy controvertido ${ }^{25}$. Lo cierto es que se percibe en la práctica una amplia aceptación en torno al hecho de que la mediación "in the cases of international child abduction, represent an efficient way to prevent disputes, which is compatible with and complementary to the applicable legal instruments, while favouring the interest of the child" ${ }^{26}, \mathrm{y}$ un incremento en su uso ${ }^{27}$. En particular, en todo lo referente a las modalidades de custodia de los hijos, al derecho de visita, la pensión alimenticia del menor o a la sustracción parental de menores, puede crear un clima constructivo para las negociaciones y garantizar un trato justo entre los padres ${ }^{28}$, llegando a calificarse, de hecho,

${ }^{21}$ Al respecto, nótese R. Espinosa CALABuig, "La (olvidada) perspectiva de género en el Derecho internacional privado", Freedom, Security \& Justice: European Legal Studies Rivista quadrimestrale on line sullo Spazio europeo di libertà, sicurezza e giustizia, no 3, 2019, p. 44 y ss.

${ }^{22}$ Todo lo contrario, el modelo normativo se caracteriza, precisamente, por su enorme complejidad y dispersión. Al respecto, nótese, F. Garau Sobrino, "Notas sobre la colisión de fuentes de Derecho Internacional Privado español sobre responsabilidad parental y protección del niño", $C d T$, vol. 3-1, 2011, p. 282 y ss.

${ }^{23}$ Тн. Kruger, "Enhancing Cross-Border Cooperation", en European Parliament, Recasting the Brussels IIa Regulation Workshop 8 November 2016. Compilation of briefings, Brussels, European Parliament, Directorate General for Internal Policies. Policy Department C: Citizens' Rights and Constitutional Affairs. Legal Affairs, 2016, pp. 41-42.

${ }^{24}$ Con diversas gradaciones. Nótese, así, como algunos autores insisten en el retraso que puede acarrear en los supuestos de sustracción internacional de menores (P. Beaumont, L. WalKer y J. Holliday, "Parental Responsibility and International Child Abduction in the proposed recast of Brussels IIa Regulation and the effect of Brexit on future child abduction proceedings", International Family Law Journal, Nov., 2016, pp. 309-310. Por su parte, otros autores se muestran reacios a aceptar el juego de la mediación en relación con la sustracción internacional de menores y, sin embargo, lo aceptan en materia de responsabilidad parental, siempre con ciertos condicionantes y limitaciones (M.A. GANDÍA SELLENS, "La responsabilidad parental", cit., pp. 811-813).

${ }^{25}$ M. Brosch y C.M. Mariotinni, EUFAMS II. Facilitating Cross-Border Family Life: Towards a Common European Understanding Report on the International Exchange Seminar 20 december 2019, Luxembourg, Max Planck Institut Luxembourg for Procedural Law / Universität Heidelberg, p. 15 (disponible en: https://pure.mpg.de/pubman/item/item_3250282_1/component/file_3250283/download.php\%3Fart\%3Dprojektbericht\%26id\%3D17, éste y el resto de enlaces señalados en este artículo se entienden visitados por última vez en fecha 22.4.2021).

${ }^{26}$ Council of the European Union, Conclusions of the ministerial seminar organised by the Belgian Presidency concerning international family mediation in cases of international child abduction, Brussels, 12.11.2010, 16121/10, JUSTCIV 194, p. 5.

${ }^{27}$ CH. C. Paul, "The Role of Family Mediation in Matters of Parental Responsibility", en European Parliament, Recasting the Brussels IIa Regulation, cit., pp. 21-23.

${ }^{28}$ En tal sentido, vid., por ejemplo, C. AzCÁrRaga Monzonis, "Sustracción internacional de menores: vías de actuación en el marco jurídico vigente", Revista boliviana de derecho, no 20, 2015, pp. 209-211. Igualmente, nótese, L. HECKENDORN URSCHELER, I. Pretelli, J. Curran et al, Cross-border parental child abduction in the European Union, Brussels, Directorate-General for Internal Policies. Policy Department C: Citizens' Rights and Constitutional Affairs. Civil Liberties, Justice and Home Affairs, 2015, p. 89; B. Haftel, Droit international privé Paris, Dalloz, 2a ed., 2020, p. 482 o R. Adamo, A. Frosina y G. Triolo, "Civil Justice in matrimonial matters and the matters of parental responsibility", en A. MiRANDA (Ed.), Mediation in Europe at the cross-road of different legal cultures, Roma, Aracne, 2014, p. 179. 
como un instrumento "óptimo" para afrontar esta categoría de situaciones ${ }^{29}$. Facilitándose a través de su uso, el logro de soluciones amistosas con vocación de durabilidad en relación, específicamente, con los menores involucrados en estas disputas, que permiten tomar en todo momento en consideración $-\mathrm{y}$ proteger- su interés superior ${ }^{30}$.

9. Con todo, se insiste, es necesario asumir que existen riesgos y puntos débiles de los que se debe ser consciente; y prevenirlos y superarlos para que devenga un mecanismo eficaz de resolución de este tipo de controversias ${ }^{31}$. Máxime en unas disputas tan peculiares y delicadas como son las que involucran a menores ${ }^{32}$. Una mediación a la que, en el caso concreto de la sustracción del menor, se recurre una vez se ha producido ésta, y que puede referir tanto a situaciones en las que todavía se encuentra pendiente el procedimiento ante el tribunal para decidir si procede el retorno del menor, como a otras posteriores a dicho procedimiento; incluso encontrarse ya en la fase de ejecución y buscarse con la mediación facilitar ésta $^{33}$. Y que, en todo caso, si bien puede permitir acuerdos entre los progenitores respecto del ejercicio de la responsabilidad parental va a venir habitualmente caracterizada por un alto nivel de tensión entre todos los involucrados en ella. Por parte del progenitor perjudicado, que se ve doblemente afectado por la pérdida repentina y por el potencial temor a no ver a su hijo nuevamente. Y, también, por el progenitor sustractor quien, una vez percibe plenamente las consecuencias de su accionar, puede igualmente temer a los eventuales procesos legales, a una restitución forzosa o al posible impacto negativo en los procesos de custodia ${ }^{34}$. A lo que se une, entre otros factores adicionales, la presión de cómo involucrarlos a todos ellos en una mediación de la que se espera, además, un resultado rápido ${ }^{35}$.

\section{La constatación de un amplio apoyo a la mediación como forma de resolver -y prevenir- las situaciones de sustracción de menores}

10. El recurso a la mediación en los supuestos que involucran a menores se ve apoyado ampliamente dentro y fuera de Europa. Asumiendo que, en el ámbito de la familia, primer y principal lugar de

${ }^{29}$ P. Orejudo de los Mozos, "Competencia judicial internacional y contenido de los acuerdos de mediación en la sustracción internacional de menores”, en C. Azcárraga Monzonis y P. Quinzá Redondo (Eds.), Tratado de mediación. Mediación en conflictos familiares. Tomo III, Valencia, Tirant lo Blanch, 2017, p. 183.

${ }^{30}$ Parlamento Europeo, Resolución del Parlamento Europeo, de 12 de septiembre de 2017, sobre la aplicación de la Directiva 2008/52/CE del Parlamento Europeo y del Consejo, de 21 de mayo de 2008, sobre ciertos aspectos de la mediación en asuntos civiles y mercantiles (Directiva sobre la mediación) (2016/2066(INI)), P8 TA(2017)0321 - Aplicación de la Directiva sobre la mediación (2018/C 337/01) DO C 337, de 20.9.2018, Conclusión principal (8). En el mismo sentido, M. CAROLL, U. BRIANT, Z. Németh et al, La médiation dans les cas illicites de l'enlèvement international d'enfants - une solution à l'amiable dans l'intérêt des enfants. Manuel pour les médiateurs et autres experts, Ministry of Justice Hungary, Bundesamt für Justiz, Minisière de la Justice RF, Országos Bírósági Hivatal, 2014, pp. 91-92 (disponible en: https://www.observatoiredesmediations. org/Documentation/Bibliographie?ID=75) o P. OReJudo de Los Mozos, "Mediación y sustracción internacional de menores", en F. Aldecoa Luzárraga y J.J. Forner Delaygua (Dirs.), La Protección de los niños, cit., pp. 369-371. Nótese, igualmente, sobre las ventajas ofrecidas por la mediación en este ámbito, G. PALAo MoReno, "Mediación y Derecho internacional privado", en E. M. Vázquez Gómez, M. Dolores Adam Muñoz y N. Cornago Prieto (Coords.), El arreglo pacífico de controversias internacionales, Tirant lo Blanch, Valencia, 2013, pp. 650-654; F. CALvo BABío, "La mediación en la sustracción internacional de menores", en M. GonZalo Quiroga (Dira.-Eda.), Métodos alternativos de solución de conflictos desde una perspectiva multidisciplinar, Madrid, Dykinson, 2006, pp. 173-175; A. HernÁndez RodríGuez, "Mediación y secuestro internacional”, cit., p. 136.

${ }^{31} \mathrm{Al}$ respecto, M.L. Soto Rodríguez, "La mediación en la sustracción internacional de menores en la Unión Europea", Revista de Estudios Europeos, $\mathrm{n}^{\circ}$ 71, 2018, p. 162.

${ }^{32}$ Considérese al respecto, F.J. Forcada Miranda, Sustracción internacional de menores y mediación familiar, Madrid, Sepin, 2015, pp. 105-136

${ }^{33}$ Vid. C.M. CAamiña Domínguez, "La mediación ante el secuestro internacional de menores", Revista internacional de estudios de Derecho internacional y arbitraje, 1, 2011, pp. 25-26. Al respecto, igualmente, Hague Conference On PRIVATE INternational Law, Guía de Buenas Prácticas en virtud del Convenio de La Haya de 25 de octubre de 1980 sobre los Aspectos Civiles de la Sustracción Internacional de Menores. Mediación, La Haya, Hague Conference on Private International Law, 2012, p. 44 y ss. o P. OREJUdo DE Los Mozos, “Competencia judicial internacional”, cit., pp. 190-194.

${ }^{34} \mathrm{Al}$ respecto, Service Social International, Resolver los conflictos familiares, cit., pp. 68-70.

${ }^{35}$ Vid. Hague Conference on Private International Law, Guía de Buenas Prácticas, cit., p. 28 o P. Orejudo de los Mozos, "Competencia judicial internacional", cit., p. 184. 
socialización del menor, "les conséquences du conflit ont un coût élevé pour les parents et, plus encore, pour les enfants" 36 , lo que favorece el fomento de medios que faciliten el consenso en las soluciones frente a la imposición ${ }^{37}$.

11. Con un carácter cuasi-universal, así se ha producido, por ejemplo, en el marco del Convenio sobre los derechos del niño ${ }^{38}$. El Comité de los Derechos del niño en su Observación General n ${ }^{\circ}$. 2 (2002) sobre el papel de las instituciones nacionales independientes de los derechos humanos en la promoción y protección de los derechos del niño ${ }^{39}$, en relación con el ejercicio de los derechos de los menores, apuesta por "Entablar, cuando proceda, procesos de mediación o conciliación antes de que se recurra a una acción judicial" 40 .

12. Por su parte, la Observación General n ${ }^{0} .12$ (2009) del Comité de los Derechos del niño ${ }^{41}$ apoya el doble entendimiento del derecho a "ser escuchado en todo procedimiento judicial o administrativo que afecte al niño" recogido en el artículo 12.2 del Convenio, en el sentido, primero, de que engloba a "a todos los procedimientos judiciales pertinentes que afecten al niño, sin limitaciones", esto es, también a las cuestiones surgidas como consecuencia del traslado ilícito del menor. Y, segundo, de que la referencia a "procedimiento judicial o administrativo" abarca a los distintos "mecanismos alternativos de solución de diferencias, como la mediación o el arbitraje" ${ }^{" 42}$.

\section{El Consejo de Europa}

13. En el caso específico de Europa, el fomento del recurso a la mediación en relación con los litigios de familia y, en concreto, con respecto a la problemática generada por la sustracción internacional de menores, se hace explícita en el seno del Consejo de Europa. En su momento, se aprobó en su seno la Recomendación $\mathrm{n}^{\mathrm{o}}$. (98)1 de 21 de enero 1998 del Comité de Ministros a los Estados miembros en mediación familiar ${ }^{43}$, que, más allá del impacto económico que puede tener en el sistema estatal de justicia ${ }^{44}$, les recomienda introducir o promover la mediación familiar o, en su caso, reforzar la mediación familiar existente, como un medio particularmente adecuado para resolver los conflictos familiares, especialmente los transfronterizos "in a consensual manner" 45 .

\footnotetext{
${ }^{36}$ A. van Kote, "Les enfants et la médiation familiale", $A J$ Famille, 2009, p. 337.

${ }^{37}$ S. Barona VILAR, “'Justicia integral' y 'access to justice"”, cit., p. 54.

${ }^{38}$ BOE de 31.12.1990.

${ }^{39}$ COMITÉ DE LOS DERECHOS DEL NIÑO,Observación general n ${ }^{\circ} 2$ (2002). El papel de las instituciones nacionales independientes de los derechos humanos en la promoción y protección de los derechos del niño, $32^{\circ}$ período de sesiones, 13 a 31.1.2003, $\mathrm{CRC} / \mathrm{GC} / 2002 / 2,15.11 .2002$.

${ }^{40}$ COMITÉ DE LOS DERECHOS DEL NIÑo, Observación general $n^{\circ} 2$, cit., p. 7, q).

${ }^{41}$ COMITÉ De LOS DERECHOS DEL NiÑo, Observación general $n^{\circ} 12$ (2009). El derecho del niño a ser escuchado, $51^{\circ}$ período de sesiones, Ginebra, 25.5 a 12.6 de 2009, CRC/C/GC/12, 20.7.2009.

${ }^{42}$ COMITÉ DE LOS DERECHOS DEL NIÑO, Observación general $n^{\circ} 12$, cit., p. 12, n ${ }^{\circ} .32$.

${ }^{43}$ Diponible en: https://search.coe.int/cm/Pages/result details.aspx?ObjectID=09000016804ecb6e

${ }^{44}$ Vid. P. Orejudo DE Los Mozos, "Mediación y sustracción internacional”, cit., p. 368, citando en este sentido la Recomendación del Comité de Ministros del Consejo de Europa núm. R (86) 12, de 16.9.1986, del Consejo de Europa, sobre medidas para prevenir y reducir la excesiva carga de trabajo de los tribunales. Igualmente, G. De Palo, A. Feasley y F. ORECCHINI, Quantifying the cost of not using mediation - a data analysis, Brussels, European Parliament. Directorate General for Internal Policies. Policy Department C: Citizens' Rights and Constitutional Affairs. Legal Affairs, 2011, pp. 4-5.

${ }^{45}$ Punto VI Promotion and Access to mediation, letra c). Una valoración de la realidad práctica de estas medidas impulsadas por el Consejo de Europa se encuentra en EuROPEAN COMMISSION FOR THE EFFICIENCY OF Justice (CEPEJ),Analysis on Assessment of the Impact of Council of Europe Recommendations Concerning Mediation, Working group on mediation (CEPEJ-GTMED)CEPEJ (2007) 12, Strasbourg, 3.5.2007 (disponible en: http://anterior.cumbrejudicial.org/html-cumbres/Referentes Internacionales de Justicia/Ref Int por temas/DOCUMENTOS/MEDIACION/MEDIACION_CEPEJ 2007_12.doc). Nótese, igualmente, EUROPEAn Commission FOR the EFFICIENCY of JUSTICE (CEPEJ), Guidelines for a better implementation of the existing recommendation concerning family mediation and mediation in civil matters, Strasbourg, 7.12.2007, CEPEJ(2007)14 (disponible en: http://anterior.cumbrejudicial.org/html-cumbres/Referentes_Internacionales_de_Justicia/Ref_Int por_temas/ DOCUMENTOS/MEDIACION/MEDIACION_CEPEJ 2007 14.doc).
} 
La Recomendación destaca, igualmente, que la "International mediation should be considered as an appropriate process in order to enable parents to organise or reorganise custody and access, or to resolve disputes arising following decisions having been made in relation to those matters." ${ }^{\text {46 }}$ Aunque específicamente desaconseje su uso "in the event of an improper removal or retention of the child... if it would delay the prompt return of the child".

14. La Recomendación, que se verá culminada con la aprobación, años después, en 2019, de un European Handbook for Mediation Lawmaking ${ }^{47}$, explicita una serie de premisas sobre las que debe articularse el uso de la mediación en este ámbito. E incide en la necesidad de que los Estados faciliten la aprobación de los acuerdos de mediación por una autoridad judicial u otra autoridad competente, cuando las partes así lo soliciten. A la vez que articulan mecanismos para la aplicación de dichos acuerdos aprobados, en consonancia con la ley nacional ${ }^{48}$.

15. La apuesta por el uso de la mediación en el ámbito del Derecho de familia y, también, especialmente, en relación con las situaciones litigiosas que involucren a menores, se patentiza, igualmente, en el artículo 13 de la Convención Europea sobre el Ejercicio de los Derechos del Niño adoptada en el seno del Consejo de Europa el 25 de enero de $1996^{49}$. El precepto, rubricado "Mediación y otros sistemas de resolución de controversias", señala con carácter genérico que con "el fin de prevenir o de resolver las controversias y de evitar los procedimientos que afecten a los niños ante una autoridad judicial, las Partes fomentarán la práctica de la mediación o de cualquier otro sistema de resolución de controversias y su utilización para llegar a un acuerdo en los casos oportunos que las Partes determinen".

16. Todo este proceso se desarrolla en el marco del fomento de una "child-friendly justice" ${ }^{50}$, en la que la mediación ha de jugar un papel protagonista, fomentándose su uso, y el de otros mecanismos similares, dentro y fuera del proceso, como un vehículo para alcanzar un mayor nivel de satisfacción para todos los afectados, incluidos los padres ${ }^{51}$. Y encuentra un paso adicional muy relevante en la aprobación por el Consejo de Europa de su Resolución 1291 (2002), de 26 de junio de 2002, sobre "L'enlèvement international d'un enfant par l'un des parents" 52 , que invita a los Estados miembros del Consejo de Europa "à développer la médiation familiale pour prévenir le rapt parental et à aider à la résolution des conflits familiaux" 53 , asumiendo su doble función preventiva y de instrumento útil con vistas a resolver la situación creada por el traslado ilícito del menor ${ }^{54}$.

${ }^{46}$ Punto VIII. International matters, letra b). En relación con este punto, vid. G. PaLao Moreno, "La mediación familiar internacional”, en J.M. LLOPIS GINER (Ed.), Estudios sobre la Ley valenciana de mediación familia, Valencia, Editorial Práctica de Derecho, 2003, pp. 71-72.

${ }^{47}$ Vid., European Commission for the Efficiency of Justice (CEPEJ), European Handbook for Mediation Lawmaking. As adopted at the 32th plenary meeting of the CEPEJ Strasbourg, 13 and 14 June 2019 (disponible en: https://rm.coe.int/cepej2019-9-en-handbook/1680951928).

${ }^{48}$ Ideas sobre las que se incide en la Recommendation Rec (2002)10 of the Committee of Ministers to member States on mediation in civil matters (Adopted by the Committee of Ministers on 18.9.2002 at the 808th meeting of the Ministers' Deputies) en la que se desgranan todo un conjunto de principios sobre los que debe articularse la mediación a desarrollar (disponible en: http://anterior.cumbrejudicial.org/html-cumbres/Referentes_Internacionales_de_Justicia/Ref_Int_por_temas/DOCUMENTOS/MEDIACION/MEDIACION_Rec_2002_10.doc).

${ }^{49}$ BOE de 21.2.2015.

${ }^{50}$ Council of Europe, Guidelines of the Committee of Ministers of the Council of Europe on child-friendly justice (adopted by the Committee of Ministers of the Council of Europe on 17 November 2010 and explanatory memorandum), Strasbourg, Council of Europe Publishing, 2011. De acuerdo con ellas, "child-friendly justice" refers to justice systems which guarantee the respect and the effective implementation of all children's rights at the highest attainable level, bearing in mind the principles listed below and giving due consideration to the child's level of maturity and understanding and the circumstances of the case. It is, in particular, justice that is accessible, age appropriate, speedy, diligent, adapted to and focused on the needs and rights of the child, respecting the rights of the child including the rights to due process, to participate in and to understand the proceedings, to respect for private and family life and to integrity and dignity." (Ibid., p. 17).

${ }^{51}$ Council of Europe, Guidelines of the Committee, cit., p. 91, no. 136.

${ }^{52}$ Disponible en: http://assembly.coe.int/nw/xml/XRef/Xref-XML2HTML-FR.asp?fileid=17022\&lang=FR

${ }^{53}$ Punto 5.

${ }^{54}$ P. ORejudo de los Mozos, "Mediación y sustracción internacional”, cit., p. 370; G. Palao Moreno, "La mediación familiar internacional", cit.p. 71. 
17. Un apoyo a los MASC, especialmente focalizado en la figura de la mediación, que, en cualquier caso, encuentra como límite infranqueable la obligación de "best serve the child's best interests", sin que, además, en modo alguno pueda entrañar su uso el privar a éste del recurso a los tribunales estatales $^{55}$. Lo que implica, entre otros extremos, el deber de informar debidamente al menor de la existencia de una posibilidad real $-\mathrm{y}$ plural- de acudir a los tribunales estatales o a mecanismos MASC ${ }^{56}$. Y de que, en todo caso, sea cual sea la opción preferida, ésta no deberá socavar su derecho de acceso a la justicia ${ }^{57}$. No se trata de obligar a nadie a valerse de uno u otro medio, sino de informar sobre su existencia y sus aparentes ventajas, asegurándole similares niveles de protección en ambos planos $^{58}$.

18. Como colofón de toda esta apuesta en favor del recurso a la mediación en relación con las disputas que involucran a menores y, en concreto, a las relativas al traslado ilícito de éstos desarrollado en el seno del Consejo de Europa, se aprobará en 2015 la Recomendación CM/Rec(2015)4 of the Committee of Ministers to member States on preventing and resolving disputes on child relocation ${ }^{59}$, que apoya la puesta en práctica de medidas tendentes a evitar las disputas en relación con la reubicación de menores y sus consecuencias.

Entre ellas se incluye el recurso a la mediación "to assist parents or other holders of parental responsibilities in reaching an agreement" ${ }^{" 60}$. Siempre, de nuevo, en condiciones de igualdad en cuanto a la salvaguarda de sus derechos con los tribunales estatales ${ }^{61}$. Y con la excepción, eso sí, de ciertas situaciones como las surgidas en un contexto de violencia de género. Debido a que, como la propia Recomendación afirma, ésta se alinea con el mandato del artículo 48.1 del Convenio del Consejo de Europa sobre prevención y lucha contra la violencia contra la mujer y la violencia doméstica, hecho en Estambul el 11 de mayo de $2011^{62}$, que explicita que las "Victims of domestic violence and their abusers are unlikely to enter the alternative dispute resolution process on an equal level, since factors such as fear and the psychological consequences of domination, control and abuse will have an impact"63.

\section{La Conferencia de La Haya de DIPr}

19. No sólo el Consejo de Europa ha optado por favorecer decididamente el recurso a la mediación como vía para la resolución de las controversias en materia de sustracción internacional de menores. También lo ha hecho de forma constante y amplia la Conferencia de La Haya de Derecho Internacional Privado ${ }^{64}$, incidiendo en su apuesta en pro del fomento del recurso a estos mecanismos en las diversas materias cubiertas por ella ${ }^{65}$. En este sentido, la Declaración de Washington "on Inter-

\footnotetext{
${ }^{55}$ Council of Europe, Guidelines of the Committee, cit., pp. 25, nº. 24, y 47, $\mathrm{n}^{\circ} .22$.

${ }^{56}$ Council of Europe, Guidelines of the Committee, cit., p. $59, \mathrm{n}^{\circ} .54$.

${ }^{57}$ Council of Europe, Guidelines of the Committee, cit., p. 70, $\mathrm{n}^{\mathrm{o}} .81$.

${ }^{58}$ Council of Europe, Guidelines of the Committee, cit., pp. 70 y $71, \mathrm{nn}^{\circ} .82$ y 84.

${ }^{59}$ Council of Europe, Recommendation CM/Rec(2015)4 of the Committee of Ministers to member States on preventing and resolving disputes on child relocation Adopted by the Committee of Ministers on 11.2.2015 at the 1219th meeting of the Ministers' Deputies (disponible en: https://wcd.coe.int/ViewDoc.jsp?id=2289331\&Site=COE\&BackColorInternet=C3C3C3\&BackColorIntranet=EDB021\&BackColorLogged=F5D383).

${ }^{60}$ Council of Europe, Recommendation CM/Rec(2015)4, cit., Principio 4.

${ }^{61}$ Council of Europe, Recommendation CM/Rec(2015), cit., pp. 19, nº 45 y 20, no. 48.

${ }^{62}$ BOE de 6.6.2014. El precepto señala que: "1. Las Partes adoptarán las medidas legislativas o de otro tipo necesarias para prohibir los modos alternativos obligatorios de resolución de conflictos, incluidas la mediación y la conciliación, en lo que respecta a todas las formas de violencia incluidas en el ámbito de aplicación del presente Convenio."

${ }^{63}$ Council of Europe, Recommendation CM/Rec(2015)4, cit., p. 23, nº 64.

${ }^{64} \mathrm{Al}$ respecto, M.L. Soto Rodríguez, "La mediación en la sustracción”, cit., pp. 159-161.

${ }^{65}$ Así, por ejemplo, lo hace el art. 6.2.d) del Convenio de 23.11.2007 sobre Cobro Internacional de Alimentos para los Niños y otros Miembros de la Familia, DO L 192, de 22.7.2011 que compele a las autoridades centrales a "promover la solución amistosa de diferencias a fin de obtener el pago voluntario de alimentos, recurriendo cuando sea apropiado a la mediación, la conciliación o mecanismos análogos". Al respecto, N. GonzÁlez MARTíN, "La mediación en casos de sustracción internacional de menores por uno de los progenitores y los acuerdos voluntarios transfronterizos: el caso mexicano", Boletín Mexicano de Derecho Comparado, año XLVII, nº 141, 2014, p. 870.
} 
national Family Relocation" ${ }^{66}$, apoyada por la Conferencia, ampara de forma explícita la promoción del recurso a la mediación, y a otros mecanismos alternativos de resolución de disputas, intra y extraprocesales, con vistas a lograr "The voluntary settlement of relocation disputes between parents" como objetivo principal ${ }^{67}$.

20. En este sentido, el fomento de la mediación -y de otros mecanismos MASC ${ }^{68}$ - como forma de prevenir ${ }^{69}$, y/o resolver, este tipo de disputas, ya se encuentra presente en el Convenio sobre los aspectos civiles de la sustracción internacional de menores, hecho en La Haya el 25 de octubre de $1980^{70}$, en el que se prevé la posibilidad del recurso a los MASC como vía para solventar los problemas surgidos una vez se ha producido la sustracción del menor ${ }^{71}$. Una opción que también aparece recogida de forma expresa en el artículo 31 del Convenio de La Haya de 19 de octubre de 1996 $6^{72}$, relativo a la Competencia, la Ley Aplicable, el Reconocimiento, la Ejecución y la Cooperación en materia de Responsabilidad Parental y de Medidas de Protección de los Niños que atribuye a las autoridades centrales de los Estados contratantes la obligación de adoptar, ya sea de forma directa o con la cooperación de autoridades públicas o de otros organismos, "todas las medidas apropiadas para: ... b) facilitar por la mediación, la conciliación o cualquier otro procedimiento análogo, acuerdos amistosos para la protección de la persona o de los bienes del niño, en las situaciones a las que se aplica el Convenio;...”’3.

21. En línea con ello, el artículo 7 del Convenio de 1980 señala que, en el marco de las actuaciones de colaboración que deben realizar las autoridades centrales de los distintos Estados contratantes, con el fin de garantizar la restitución inmediata del menor y conseguir el resto de objetivos previstos en el Convenio, ya sea directamente o a través de un intermediario, deberán, entre otras, “c) Garantizar la restitución inmediata del menor o facilitar una solución amigable" "74. Una obligación de procurar una solución amistosa, que se vincula al mandato del artículo 10 de adoptar o hacer adoptar todas las medidas "adecuadas encaminadas a conseguir la restitución voluntaria del menor". Y que, si bien ha sido interpretada de muy diversas formas por las autoridades centrales de los distintos Estados parte en el

${ }^{66}$ International judicial conference on cross-border family relocation, Washington, D.C., United States of America, 23-25 March 2010, co-organised by The Hague Conference on Private International Law and the International Centre for Missing and Exploited Children with the support of United States Department of State (disponible en: https://www.hcch.net/es/news-archive/details/?varevent $=188$ ).

${ }^{67}$ Punto 8. Exigiendo tomar en consideración los puntos de vista de los menores "having regard to the child's age and maturity, within the various processes" (disponible en: https://www.icmec.org/press/washington-declaration-on-internationalfamily-relocation/).

${ }^{68}$ Vid. Hague Conference on Private International Law, Guía de Buenas Prácticas, cit., pp. 97-99.

${ }^{69}$ Vid. Hague Conference on Private International Law, Guía de Buenas Prácticas, cit., p. 96. En relación con esta idea de prevención, vid. C.M. CAAmiÑa Domínguez, "La mediación ante el secuestro", cit., p. 27; C. Carrillo Lerman, "Mediación familiar internacional y sustracción de menores", BARATARIA Revista Castellano-Manchega de Ciencias Sociales, $\mathrm{n}^{\circ}$. 19, 2015, p. 187, señalando en la p. 189 distintos supuestos en los que resulta especialmente interesante su exploración.

${ }^{70}$ BOE de 24.8.1987. La Guía de Buenas Prácticas elaborada en el marco de la Conferencia de La Haya apuesta por el recurso a la mediación y a otros mecanismos de resolución alternativa de disputas también respecto de aquellas situaciones que quedan fuera del ámbito de aplicación del texto de 1980 (y del de 1996). Vid. Hague Conference on Private International LAW, Guía de Buenas Prácticas, cit., pp. 99-101).

${ }^{71}$ Aunque también, se dice, tiene una importante función que cumplir, precisamente, una función preventiva. En tal sentido, A. HernÁNDEZ Rodríguez, "Mediación y secuestro internacional", cit., p. 141.

${ }^{72}$ BOE de 2.10.2010

${ }^{73} \mathrm{Al}$ respecto, N. González Martín, "La mediación en casos", cit., p. 869. Igualmente, nótese, Hague Conference on Private International Law, Manual práctico sobre el funcionamiento del Convenio de La Haya de 19 de octubre de 1996 relativo a la competencia, la ley aplicable, el reconocimiento, la ejecución y la cooperación en materia de responsabilidad parental y de medidas de protección de los niños, La Haya, Conferencia de La Haya de Derecho Internacional Privado, 2014, pp. 160-164.

${ }^{74}$ Nótese al respecto, B. Gómez BengoecheA, Aspectos civiles de la sustracción internacional de menores: problemas de aplicación del Convenio de La Haya de 25 de octubre de 1980, Madrid, Dykinson, 2002, pp. 102-108 o C.M. CAAMIÑA Domínguez, "La mediación ante el secuestro", cit., p. 28. Sobre el papel a jugar por las autoridades centrales en el proceso de mediación, vid. Hague Conference on Private International Law, Guía de Buenas Prácticas, cit., p. 45 y ss. 
Convenio ${ }^{75}$ se ha entendido que, en todo caso, podía permitir la resolución de un número "considerable" de supuestos, sin necesidad de tener que recurrir a los tribunales.

Correlativamente, corresponderá igualmente a la autoridad central "decidir en qué momento han fracasado los intentos llevados a cabo para garantizar la 'restitución voluntaria' del menor, o para facilitar una 'solución amigable""’76.

22. Esta referencia a la "solución amigable" presente en el artículo 7.c) del Convenio de 1980, se tornará con el paso del tiempo en una mención directa y explícita al instituto de la mediación. En tal sentido, en 2001, en el marco de la Cuarta reunión de la Comisión especial sobre el funcionamiento del Convenio de La Haya de 25 de octubre de $1980^{77}$ se adoptó, entre sus conclusiones y recomendaciones, una mención genérica al hecho de que las "Autoridades Centrales deberían intentar siempre la restitución voluntaria del niño tal como lo prevé el artículo 7 c) del Convenio". Apuntando para ello que, en la medida de lo posible, y cuando sea apropiado, procederán a dar instrucciones a los juristas implicados, ya sean el Ministerio fiscal o abogados ejercientes, o dirigirán a las partes a un organismo especializado que proporcione un adecuado servicio "de mediación"78. Sin que, en cualquier caso, esta exploración de soluciones amigables pueda suponer "retrasos indebidos en el procedimiento de restitución"79.

23. Esta posición favorable al uso de la mediación como vía de resolución de las disputas vinculadas a la sustracción internacional de menores se ve adicionalmente profundizada en las Conclusiones y Recomendaciones de la quinta reunión de la Comisión Especial para la revisión del funcionamiento del Convenio de La Haya de $1980^{80}$, celebrada en el otoño de $2006^{81}$. Previamente, en abril de ese mismo año, los Estados Miembro de la Conferencia de La Haya habían autorizado a la Oficina Permanente a preparar un estudio de "factibilidad sobre mediación transfronteriza en asuntos de familia", que comprendiese el posible desarrollo de un instrumento en la materia ${ }^{82}$, al amparo del cual se elaboró, en 2012, una Guía de Buenas Prácticas ${ }^{83}$ en relación con el uso de la mediación en situaciones de sustracción de menores ${ }^{84}$.

${ }^{75} \mathrm{Al}$ respecto Conferencia de La Haya de Derecho Internacional Privado, Guía de buenas prácticas en virtud del Convenio de La Haya del 25 de octubre de 1980 sobre los aspectos civiles de la sustracción internacional de menores. Primera Parte - Práctica de las autoridades centrales, Bristol, Family Law, 2003, p. 53. También, P. Orejudo de Los Mozos, "Mediación y sustracción internacional", cit., p. 372, nota 26.

${ }^{76}$ E. Pérez Vera, Informe explicativo del Convenio HCCH sobre los Aspectos Civiles de la Sustracción Internacional de Menores, p. 27 nº. 92 (disponible en: https://assets.hcch.net/docs/43df3dd9-a2d5-406f-8fdc-80bc423cdd79.pdf).

${ }^{77}$ Conferencia de La Haya de Derecho Internacional Privado, Conclusiones y Recomendaciones de la Cuarta Reunión de la Comisión especial sobre el funcionamiento del Convenio de La Haya de 25 de octubre de 1980 sobre los aspectos civiles de la sustracción internacional de menores (22-28 de marzo de 2001) redactadas por la Oficina Permanente (disponible en: https://www.hcch.net/upload/concl28sc4_s.pdf).

${ }^{78} \mathrm{~N}^{\mathrm{o}} 1.10$. En esta tarea se resaltaba el importante papel jugado por los tribunales de justicia.

${ }^{79} \mathrm{~N}^{\mathrm{o}} 1.11$.

${ }^{80}$ Conferencia de La Haya de Derecho Internacional Privado, Conclusiones y recomendaciones de la quinta reunión de la Comisión Especial para revisar el funcionamiento del Convenio de La Haya de 25 de octubre de 1980 sobre los aspectos civiles de la sustracción internacional de menores y la implementación práctica del Convenio de La Haya de 19 de octubre de 1996 relativo a la competencia, la ley aplicable, el reconocimiento, la ejecución y la cooperación en materia de responsabilidad parental y de medidas de protección de los niños (30 de octubre-9 de noviembre de 2006) adoptadas por la Comisión Especial (disponible en: https://assets.hcch.net/upload/concl28sc5_s.pdf).

${ }^{81} \mathrm{~N}^{\mathrm{o}} 1.3 .1$

82 Vid. Hague Conference on Private International Law, Proyecto de guía de buenas prácticas en virtud del Convenio de La Haya de 1980 sobre los Aspectos Civiles de la Sustracción Internacional de Menores. Quinta parte - mediación redactado por la Oficina Permanente (traducción no revisada), Doc. Prel. nº 5, mayo de 2011, p. 14 (disponible en: https://www.hcch. net/upload/wop/abduct2011pd05e.pdf).

${ }^{83}$ Vid. nota 75 supra.

${ }^{84}$ En relación con ella nótese, entre otros, N. GonZÁLEZ MArTín, "La mediación en casos", cit., pp. 876-885; N. GonZÁLEZ Martín, "International Parental Child Abduction and Mediation", Anuario Mexicano de Derecho Internacional, vol. XV, 2015, p. 363 y ss.; Hague Conference on Private International Law, Contacto transfronterizo relativo a los niños. Principios generales y Guía de buenas prácticas, 2010, pp. x y xi, y 6 y ss. (disponible en: https://assets.hcch.net/docs/230b60d3-0418-4cc0a2f1-fdcb6add9605.pdf) o F.J. ForCAdA MiRANDA, Sustracción internacional de menores, cit., pp. 143-145. 
Esta Guía, la quinta elaborada por la Conferencia en relación con el Convenio, aun careciendo de carácter vinculante para los Estados parte en el texto de $1980^{85}$, cuenta con vocación de aplicación, no sólo respecto de aquellos países que son parte del Convenio de La Haya de 1980 sino, también, de los que lo son en otros Convenios de la Conferencia que promueven el acuerdo amistoso de disputas ${ }^{86}$.

24. La Guía se articula en torno a un concepto amplio de mediación: "la mediación" dice "puede definirse como un proceso voluntario y estructurado mediante el cual un 'mediador' facilita la comunicación entre las partes de un conflicto, permitiendo que ellas se hagan cargo de encontrar una solución para este conflicto" "87. Plasmándose el eventual resultado exitoso en el denominado "acuerdo de mediación"

La Guía resalta algunos de los principios que caracterizan a la figura. Entre otros: voluntariedad $^{89}$, consentimiento informado ${ }^{90}$, neutralidad, independencia, imparcialidad y justicia ${ }^{91}$, confidencialidad $^{92} \mathrm{o}$ imprescindible consideración del interés y el bienestar del niño en cuestión ${ }^{93}$. Con la necesaria toma de decisiones fundadas y acceso apropiado a asesoramiento jurídico ${ }^{94}$, y la previsión de una posible participación del menor, dependiendo de su edad y grado de madurez, en los procedimientos de restitución de La Haya y en el resto de procedimientos de derecho de familia ${ }^{95}$.

25. A partir de la aceptación de la premisa, no por obvia eximida de ser enfatizada, de que no todos los conflictos de familia son susceptibles de resolución de manera amigable, exigiéndose, incluso, en algunos casos la intervención de una autoridad judicial ${ }^{96}$. O del hecho de que existen otros distintos -como los que involucran situaciones de violencia de género o doméstica ${ }^{97}$ - cuyo sometimiento a mediación plantea grandes dudas o, directamente, no cabe -recuérdese el tenor del artículo 48.1 del mencionado Convenio de Estambul o el artículo 87 ter.5 de la Ley Orgánica 6/1985, de 1 de julio, del Poder Judicial98-, la Guía apuesta por "realizar todas las gestiones adecuadas para alentar a las partes de una controversia familiar transfronteriza respecto de los niños a lograr una solución amistosa para su controversia" 99 .

\footnotetext{
${ }^{85}$ Hague Conference on Private International Law, Guía de Buenas Prácticas, cit., p. 12.

${ }^{86}$ Hague Conference on Private International Law, Guía de Buenas Prácticas, cit., p. 12; M.C. Chéliz Inglés, "Alcance y retos de la mediación en la sustracción internacional de menores: Países no contratantes del Convenio de La Haya de 1980", en R. Grasa Hernández, A. Blanc Altemir y P. Diago Diago (Dirs.), La aplicación de la mediación en la resolución de los conflictos en el Mediterráneo (iniciativa para la mediación en el Mediterráneo, Madrid, MAEC/AEPDIRI, 2015, pp. 270-273. Un listado de los textos de la Conferencia de La Haya donde se prevé el recurso a la mediación, se encuentra en A. HERNÁNDEZ RODRÍGUEZ, "Mediación y secuestro internacional”, cit., p. 138.

${ }^{87}$ Hague Conference on Private International Law, Guía de Buenas Prácticas, cit., p. 7. La Guía apunta, de forma gráfica, un elenco de posibles supuestos susceptibles de ser sometidos a mediación y las ventajas que se derivan de ello (Ibid., p. 21, $\left.\mathrm{n}^{\mathrm{o}} .30\right)$. En contraste con la mediación, la conciliación es entendida como "un mecanismo de solución de controversias en el que un tercero imparcial asume un rol activo y directivo a fin de ayudar a las partes a encontrar una solución amistosa respecto de su controversia. La mediación puede ser proactiva, pero no directiva. A efectos de la mediación, el énfasis debe recaer en el hecho de que el propio mediador no se encuentra en condiciones de tomar una decisión en nombre de las partes, sino que sólo ayuda a las partes a encontrar su propia solución. En cambio, el conciliador puede guiar a las partes hacia una solución concreta" (Ibid., p. 8).

${ }^{88}$ La Guía de Buenas Prácticas lo califica como el "resultado de la mediación, i.e., el acuerdo amistoso alcanzado por las partes durante el proceso de mediación” (Hague Conference on Private International Law, Guía de Buenas Prácticas, cit., p. 10).

${ }^{89}$ Hague Conference on Private International Law, Guía de Buenas Prácticas, cit., pp. 61-62.

${ }^{90}$ Hague Conference on Private International Law, Guía de Buenas Prácticas, cit., pp. 62-63.

${ }^{91}$ Hague Conference on Private International Law, Guía de Buenas Prácticas, cit., p. 63.

${ }^{92}$ Hague Conference on Private International Law, Guía de Buenas Prácticas, cit., pp. 64-66.

${ }^{93}$ Hague Conference on Private International Law, Guía de Buenas Prácticas, cit., p. 67.

${ }^{94}$ Hague Conference on Private International Law, Guía de Buenas Prácticas, cit., pp. 67-68.

${ }^{95}$ Hague Conference on Private International Law, Guía de Buenas Prácticas, cit., pp. 72-76. En este mismo sentido, P. OREJUdO DE LOS Mozos, "Mediación y sustracción internacional”, cit., pp. 379-381.

${ }^{96}$ Hague Conference on Private International Law, Guía de Buenas Prácticas, cit., pp. 24-25. La Guía apuesta por desarrollar una evaluación previa de la aptitud del caso para ser resuelto a través de la mediación (Ibid., p. 51 y ss).

${ }^{97}$ Hague Conference on Private International Law, Guía de Buenas Prácticas, cit., p. 79 y ss.

${ }^{98}$ BOE de 2.7.1985.

${ }^{99}$ Hague Conference on Private International Law, Guía de Buenas Prácticas, cit., p. 22.
} 
Y ello, en cuanto se entiende que la institución presenta ventajas singulares en este ámbito, al facilitar la comunicación entre las partes en un entorno informal, y permitirles que desarrollen su propia estrategia en torno a cómo superar el conflicto ${ }^{100}$. Permitiendo facilitar al menor el ejercicio de su derecho a mantener regularmente "relaciones personales y contactos directos con ambos progenitores" ${ }^{101}$. Y facilitando, en su caso, y dependiendo de su edad y nivel de madurez, la escucha del menor ${ }^{102}$. Siempre, eso sí, sujeto a la necesaria salvaguarda de su interés superior ${ }^{103}$.

26. Sin embargo, la propia Guía insiste en el hecho de que el recurso a la mediación debe realizarse diseñando las necesarias "salvaguardias y garantías" con el fin de evitar que la posible participación en una mediación pueda resultar desventajosa para cualquiera de las partes ${ }^{104}$. O les prive de su derecho a acudir a los tribunales estatales, respecto de los que, se reitera, la mediación tiene una naturaleza complementaria, no sustitutiva ${ }^{105}$. Ello implicaría en última instancia, atendiendo al tenor de la Observación general n. ${ }^{\circ} 12$ del Comité de los derechos del niño, que, en caso de remisión a medios extrajudiciales, incluida la mediación, "el niño debe tener la oportunidad de dar su consentimiento libre y voluntario y de obtener asesoramiento y asistencia jurídicos y de otro orden acerca de lo apropiado y conveniente de la remisión ofrecida"106.

27. La opción en favor de la mediación, además, no debe generar demoras injustificadas en los eventuales procesos pendientes ante los tribunales ${ }^{107}$. Y en ella debe tomarse en consideración, en todo momento, el grado adicional de complejidad -especialmente, pero no sólo, jurídica ${ }^{108}$-, que incorpora un litigio $-\mathrm{y}$, lógicamente, una mediación- transfronterizo en contraste con uno estrictamente interno ${ }^{109}$. Y que, entre otros extremos, afecta a su contenido ${ }^{110}$, y a la ejecutoriedad del posible acuerdo fuera de las fronteras del país en que se ha alcanzado ${ }^{111}$.

${ }^{100}$ Sobre todas estas ventajas vid. Hague Conference on Private International Law, Guía de Buenas Prácticas, cit., p. 23.

${ }^{101}$ Art. 9.3. Sobre los posibles planes de parentalidad, vid. C. Valdebenito Larenas, A. Rojo Burrows y P. Campillay Díaz, "Mediación familiar y plan de parentalidad", cit., pp. 5-6.

${ }^{102}$ P. Orejudo de los Mozos, “Mediación y sustracción internacional”, cit., pp. 377-379.

${ }^{103}$ Una exigencia latente en toda actuación que involucre o afecte al menor. Nótese en este sentido, M. GonZÁLEZ MARIMÓN, Responsabilidad parental, cit., p. 638.

${ }^{104}$ Hague Conference on Private International Law, Guia de Buenas Prácticas, cit., p. 24 y p. 77 y ss.

${ }^{105}$ Hague Conference on Private International Law, Guía de Buenas Prácticas, cit., pp. 26-28. Lo que exige un desarrollo en continúa colaboración con las autoridades judiciales y administrativas (Ibid., p. 32). Sobre las exigencias mínimas que deben garantizarse para asegurar un adecuado y exitoso recurso a la mediación en este ámbito, vid. P. OREJUdO DE LOS MozOs, "Mediación y sustracción internacional", cit., pp. 374-375.

${ }^{106}$ COMITÉ DE LOS DERECHOS DEL NIÑO, Observación general $n^{\circ} 12$, cit., p. 17, nº 59.

${ }^{107}$ Hague Conference on Private International Law, Guía de Buenas Prácticas, cit., pp. 29-32 y pp. 58-60. En este mismo sentido, C.M. CaAmiña Domínguez, "La mediación ante el secuestro", cit., pp. 33-34 o P. Orejudo de los Mozos, "Mediación y sustracción internacional”, cit., pp. 375-377.

${ }^{108}$ Aunque también debe tenerse en consideración el posible impacto cultural, las dificultades idiomáticas, de distancia o de extranjería, entre otros extremos, vid. Hague Conference on Private International Law, Guía de Buenas Prácticas, cit., p. 33 y ss. y p. 60; S. AlLes, "Recensión a La médiation familiale internationale. La diplomatie du coeur dans les enlèvements d'enfants", Revue des politiques sociales et familiales, no. 92, 2008, p. 129 o M. CAso SeÑaL, "La mediación en los conflictos transfronterizos de sustracción de menores", Revista de Mediación, no 8-2, 2011, p. 23; EUROPEAN UnION AgENCY FOR FunDAMENTAL Rights (FRA), Children deprived of parental care found in an EU Member State other than their own. A guide to enhance child protection focusing on victims of trafficking, Luxembourg, Publications Office of the European Union, 2019, p. 57. En relación con los problemas estrictamente jurídicos susceptibles de plantearse, vid. G. PaLAo Moreno, "La sustracción internacional de menores en la jurisprudencia española", Revista de Derecho de Familia, no. 16, 2002, pp. 258 y ss.

${ }^{109}$ Hague Conference on Private International Law, Guía de Buenas Prácticas, cit., p. 28, no ${ }^{\circ}$ 51. Al respecto, y por todos, vid. G. Palao Moreno, "La mediación familiar internacional”, cit., pp. 63-65 y 67-69.

${ }^{110}$ Hague Conference on Private International Law, Guía de Buenas Prácticas, cit., p. 85 y pp. 92-95.

${ }^{111}$ Hague Conference on Private International Law, Guía de Buenas Prácticas, cit., pp. 32-33 y pp. 86-91. E incide en la exigencia de un grado adicional de formación de los mediadores (Ibid., p. 38 y ss. y p. 68). En tal sentido, igualmente, $\mathrm{CH}$. C. PAUL, "The Role of Family Mediation", cit., p. 24 y ss. En relación con este punto, resulta interesante, en cuanto diferencia las estrategias dependiendo de la edad del menor, U. Briant, "Caractéristiques de la médiation dans les cas de l'enlèvement illicite d'enfants - ce que le médiateur doit savoir et le type de médiation recommandé (solutions en ligne)”, en M. CAROLL, U. Briant, Z. Németh et al, La médiation dans les cas illicites, cit. p. 47 y ss. Igualmente, nótese M. Brosch y C.M. MariotinNi, EUFAMS II. Facilitating, cit., p. 23. 
28. La Guía ha gozado de una creciente utilización. La Séptima reunión de la Comisión Especial ${ }^{112}$, desarrollada en 2017 , se congratulará de este hecho, así como del "aumento del recurso a la mediación en los casos de sustracción internacional de niños" -sin aportar cifras al respecto- como forma de resolver las conflictos familiares internacionales comprendidos en los ámbitos de aplicación del Convenio de La Haya de 1980 y, también del Convenio de La Haya de 19 de octubre de $19966^{113}$, relativo a la Competencia, la Ley Aplicable, el Reconocimiento, la Ejecución y la Cooperación en materia de Responsabilidad Parental y de Medidas de Protección de los Niños ${ }^{114}$.

29. Esta mención a la mediación como forma de resolver las controversias que afectan a los menores se va a ver profunda, y adicionalmente, reforzada en el marco de las "Malta Judicial Conference on Cross-Frontier Family Law Issues", organizadas por el Gobierno de Malta en colaboración con la Conferencia de La Haya de Derecho internacional privado ${ }^{115}$.

30. En la primera de ellas, celebrada en marzo de 2004, ya se apostó en la Declaración final por la necesaria adopción de medidas que favorecieran el recurso a la mediación en este sector temático: "Steps should be taken to facilitate, by means of mediation, conciliation, by the establishment of a commission of good offices, or by similar means, solutions for the protection of the child which are agreed between the parents" 116 . Procediéndose, dos años después, en 2006, en la segunda de estas Conferencias, a dar la bienvenida al incremento en el uso de la mediación y de la conciliación en el ámbito del Derecho de familia internacional ${ }^{117}$.

31. La Declaración aprobada en esta segunda Conferencia tiene la virtud de incorporar algunas claves relevantes en torno a las bases en las que debería asentarse la consolidación del recurso a la mediación como vía para la resolución de las disputas surgidas en este ámbito. Así, tras señalar la necesidad de que cualquier mediación se desarrolle en una forma que tome en consideración las diferencias culturales $^{118}$, destaca, en primer lugar, la conveniencia de que en todos los procesos se favorezca los acuerdos entre los progenitores, facilitando el acceso a la mediación y a otros medios de promoción del acuerdo, sin que esto suponga demoras innecesarias. Y asegurando, en todo caso, que "where efforts to achieve agreement fail, effective access to a court should be available" ${ }^{119}$. Junto a ello, en segundo lugar, se resalta la importancia de contar con procedimientos "enabling parental agreements to be judicially approved and made enforceable in the countries concerned" ${ }^{120}$.

32. Estas ideas, fomento de la mediación, evitación de demoras, aseguramiento de la eficacia del acuerdo alcanzado - un factor éste, esencial para la consolidación de la figura como mecanismo de resolución de estas controversias ${ }^{121}$ - serán destacadas, de nuevo, tanto en la tercera Conferencia, que tuvo lugar en 2009, en la que se incidirá en las situaciones que involucran a Estados parte y no parte del

${ }^{112}$ Conferencia de La Haya de Derecho Internacional Privado, Comisión Especial sobre el funcionamiento práctico de los Convenios de La Haya de 1980 y 1996 (10 - 17 de octubre de 2017), (disponible en: https://assets.hcch.net/docs/b50c61b750a2-495c-b004-36e9000646df.pdf).

${ }^{113}$ BOE de 2.10.2010.

${ }^{114}$ Pp. 1.3.2 y 1.3.3. Que como se recuerda correctamente, carecen de carácter "erga omnes". Vid. al respecto, C.M. CAAMIÑA Domínguez, "La mediación ante el secuestro", cit., p. 29.

${ }^{115}$ En relación con este proceso, vid. L.E. Teitz, "Malta Process and Cross-Cultural Aspects in Family Disputes", en M. JÄNTERÄ-JAREBORG (Ed.), The Child's Interests in Conflict, cit., pp. 175-183.

${ }^{116}$ The Malta Judicial Conference on Cross-Frontier Family Law Issues. Hosted by the Government of Malta in Collaboration with The Hague Conference on Private International Law, Declaration n ${ }^{\circ}$ 3, p. 2 (disponible en: https://www.euromed-justice.eu/en/system/files/20090122194425 Maltajudicialconference2004.pdf)

${ }^{117}$ Second Malta Judicial Conference on Cross-Frontier Family Law Issues Hosted by the Government of Malta in Collaboration with The Hague Conference on Private International Law, Declaration $\mathrm{n}^{\mathrm{o}} 3$ (disponible en: https://www.hcch.net/ upload/maltadec12_e.pdf).

${ }_{118}$ Declaration $\mathrm{n}^{\mathrm{0}} 3$.

${ }_{119}$ Declaration $\mathrm{n}^{\mathrm{o}} 3$.

${ }^{120}$ Declaration $\mathrm{n}^{\mathrm{o}} 3$.

${ }^{121}$ M.C. CHÉLIZ InGLÉs, “Alcance y retos”, cit., pp. 268-269. 
Convenio de La Haya de $1980^{122}$, como en la cuarta, de 2016, en la que se hará especial mención a los Estados con ordenamientos jurídicos basados o influenciados por la Sharia ${ }^{123}$.

33. Precisamente, en el marco de las Conferencias de Malta se constituirá en 2009 un Grupo de Trabajo destinado a promover el desarrollo de estructuras de mediación, con objeto de ayudar a la resolución de las disputas familiares transfronterizas en relación con la custodia de, o en contacto con, menores. Incluyéndose dentro de su objeto, a los supuestos de traslado unilateral de menores a Estados no vinculados con los Convenios de La Haya de 1980 y de $1996^{124}$.

34. El Grupo de Trabajo elaboró en 2011 unos Principios para el establecimiento de estructuras de mediación en el contexto del proceso de Malta ${ }^{125}$, aplicables tanto a los supuestos en los que resultan aplicables los textos de La Haya, como a aquellos en que no lo son. Y en los que, por lo tanto, la mediación u otros mecanismos de esta naturaleza pueden llegar a constituir los únicos medios de encontrar una solución a la cuestión planteada y facilitar a los menores involucrados el mantener contacto continuado con sus progenitores ${ }^{126}$. No olvidemos, en este sentido, que un número importante de países musulmanes no forman parte del entramado convencional de la Conferencia de La Haya en materia de menores, lo que atribuye a la figura, y al resto de mecanismos de resolución alternativa de conflictos, un valor adicional de prevención y de resolución de los eventuales problemas planteados ${ }^{127}$.

35. De hecho, y fuera del ámbito de la Conferencia de La Haya, es precisamente esta posibilidad de que existan numerosos casos en los que no se aplica el Convenio, incluso en ocasiones en que técnicamente debería serlo ${ }^{128}$, la que se encuentra en la base de la creación en el seno de la UE, en 1987, por parte del Parlamento Europeo, de la figura del Mediador/a para casos de sustracción internacional de menores por sus progenitores. Renombrada, desde 2018, como Coordinadora del Parlamento Europeo para los Derechos del Niño ${ }^{129}$.

36. Los Principios para el establecimiento de estructuras de mediación tienen como objetivo el establecimiento de puntos centrales de contacto en los distintos Estados -una idea sobre la que incidirá, igualmente, en 2012, la ya abordada Guía de Buenas Prácticas en relación con el uso de la mediación en situaciones de sustracción de menores ${ }^{130}$ - dirigidos a ofrecer información, por ejemplo, sobre los servicios de mediación disponibles, o el acceso a la institución de la mediación, entre otra información relevante, en los diversos países ${ }^{131}$.

${ }^{122}$ Third Malta Judicial Conference on Cross-Frontier Family Law Issues Hosted by the Government of Malta in Collaboration with the Hague Conference on Private International Law, Declaration $\mathrm{n}^{\circ} 7$ (disponible en: https://assets.hcch.net/upload/ maltadec109_e.pdf).

${ }^{123}$ Fourth Malta Conference ("Malta IV") on Cross-Frontier Child Protection and Family Law Hosted by the Government of Malta in Collaboration with the Hague Conference on Private International Law (HCCH) "The Malta Process", Declaration $n^{\circ} 12$ (disponible en: https://assets.hcch.net/docs/91ab60a5-1ebe-46ca-91ce-72e6e55c0ae7.pdf).

${ }^{124}$ Hague Conference on Private International Law, Working party on mediation in the context of the Malta process explanatory memorandum on the principles for the establishment of mediation structures in the context of the Malta process drawn up by the Working Party with the assistance of the Permanent Bureau, p. 2 (disponible en: https://assets.hcch.net/upload/ wop/mediationmemo_e.pdf).

${ }^{125}$ Hague Conference on Private International Law, Los "Principios para el establecimiento de estructuras de mediación en el contexto del proceso de Malta" y el memorándum explicativo redactado por la oficina permanente (traducción no revisada) (disponible en: https://www.hcch.net/upload/wop/abduct2011pd06s.pdf).

${ }^{126}$ Hague Conference on Private International Law, Working party on mediation, cit., p. 3; P. Orejudo de los Mozos, "Mediación y sustracción internacional", cit., p. 373.

${ }^{127}$ Vid. al respecto, por todos, M.C. ChÉLIz Inglés, “Alcance y retos”, cit., pp. 263-265.

${ }^{128}$ E. GeBhard, Informe intermedio. Mediadora del Parlamento Europeo para casos de sustracción internacional de menores por sus progenitores, Bruselas, 1.3.2007, p. 1.

${ }^{129} \mathrm{https}$ //www.europarl.europa.eu/at-your-service/es/be-heard/coordinator-on-children-rights

${ }^{130}$ Hague Conference on Private International Law, Guía de Buenas Prácticas, cit., pp. 43-44.

${ }^{131}$ Hague Conference on Private International Law, Working party on mediation, cit., p. 3. 
37. Especialmente, los Principios inciden en distintos aspectos considerados relevantes con vistas a asegurar el éxito de la mediación en este tipo de supuestos. Se hace hincapié así, en el acuerdo alcanzado en el marco de la mediación, respecto del que se destaca que -"debe ser compatible con los sistemas jurídicos pertinentes", en consonancia con los que, previsiblemente, se desarrollará la mediación-, y que "deberían ser lo más concretos posible y tener en cuenta los aspectos prácticos pertinentes"132. Destacándose, igualmente, la necesidad de asegurar su eficacia - "Antes de procederse a la implementación del acuerdo, el acuerdo debería tornarse ejecutable o vinculante en las jurisdicciones pertinentes", "Cuando sea necesario, los países podrán analizar la conveniencia de incorporar disposiciones regulatorias o legislativas a efectos de la ejecución de los acuerdos de mediación”-133.

\section{La situación española}

38. España no ha sido ajena a esta tendencia de fomentar el recurso a la mediación y a otros mecanismos de resolución de los conflictos surgidos en el ámbito del Derecho de familia, especialmente, los referentes al traslado ilícito de menores, tanto en su exigua práctica convencional bilateral, como en el plano estrictamente interno.

39. En el primer nivel, el Convenio entre el Reino de España y el Reino de Marruecos sobre asistencia judicial, reconocimiento y ejecución de resoluciones judiciales en materia de derecho de custodia y derecho de visita y devolución de menores, de 30 de mayo de $1997^{134}$ constituye un ejemplo aislado, en cuyo artículo 4.2.c) se prevé que una de las medidas que debe adoptar, o hacer adoptar, las autoridades centrales, bien de forma directa o indirecta, es precisamente la de "Facilitar una solución amistosa, supervisar la entrega voluntaria del menor y el ejercicio del derecho de visita" ${ }^{135}$.

40. Por su parte, en el plano estrictamente interno, la Ley de Jurisdicción Voluntaria de $2015^{136}$ añadió en el Título I del Libro IV de la LEC ${ }^{137}$, un Capítulo IV bis rubricado "Medidas relativas a la restitución o retorno de menores en los supuestos de sustracción internacional" compuesto de tres artículos -778 quáter, quinquies y sexies- ${ }^{138}$.

41. El numeral 12 del artículo 778 quinquies recoge la posibilidad de que, en cualquier momento del proceso de restitución, ambas partes soliciten su suspensión de conformidad con el artículo 19.4 LEC, con objeto de someter la cuestión a mediación ${ }^{139}$. Esta opción de remitir la disputa a mediación queda también abierta al juez, quien, en todo momento, de oficio o a petición de cualquiera de las partes, podrá proponerla "si, atendiendo a las circunstancias concurrentes, estima posible que lleguen a un acuerdo, sin que ello deba suponer un retraso injustificado del proceso", procediéndose a la suspensión de las actuaciones por un plazo limitado previsto en el propio Capítulo ${ }^{140}$.

\footnotetext{
${ }^{132}$ Hague Conference on Private International Law, Los "Principios para el establecimiento, cit., Annex 1.B.3.

${ }^{133}$ Hague Conference on Private International Law, Los "Principios para el establecimiento, cit., Annex 1.C.

${ }^{134}$ BOE de 24.6.1997.

${ }^{135}$ Sobre las funciones de las autoridades centrales, vid. Fiscalía General DEL Estado, Circular 6/2015, sobre aspectos civiles de la sustracción internacional de menores, FIS-C-2015-00006, de 17.11.2015, pp. 53-55 (disponible en: https://www. boe.es/buscar/doc.php?coleccion=fiscalia\&id=FIS-C-2015-00006).

${ }^{136}$ BOE de 3.7.2015.

${ }^{137}$ BOE de 8.1.2000.

${ }^{138}$ Sobre la reforma vid, por todos, R. Espinosa CALABUig, "Traslado o retención ilícitos de menores tras la reforma de 2015: rapidez, especialización y... algunas ausencias”, REDI, vol. 68/2, julio-diciembre 2016, especialmente, p. 354.

${ }^{139} \mathrm{Al}$ respecto, M.L. Soto Rodríguez, "La mediación en la sustracción", cit., p. 156; Fiscalía General del Estado, Circular 6/2015, cit., p. 82.

${ }^{140}$ Llamativamente, el art. 778.7 quáter invita al juez, con la finalidad de facilitar las comunicaciones judiciales directas entre órganos jurisdiccionales de distintos países, si ello fuera posible y éste así lo considerase necesario, a recurrir al auxilio de las Autoridades Centrales implicadas, de las Redes de Cooperación Judicial Internacional existentes, de los miembros de la Red Internacional de Jueces de la Conferencia de La Haya y de los Jueces de enlace. Nótese, P. OreJudo de Los Mozos, "Competencia judicial internacional", cit., p. 198.
} 
42. El precepto insiste en la necesidad de que la duración de la mediación sea "lo más breve posible", y con el "mínimo número de sesiones". Añadiendo que, en todo caso, se procederá a reanudar el procedimiento judicial "si lo solicita cualquiera de las partes o, en caso de alcanzarse un acuerdo en la mediación, que deberá ser aprobado por el Juez teniendo en cuenta la normativa vigente y el interés superior del niño".

\section{El fomento de la mediación en, y por, la Unión Europea}

43. La Unión Europea (UE) no ha sido ajena a esta tendencia global en favor del fomento de la mediación como mecanismo idóneo para la resolución de disputas, también de las surgidas en el ámbito familiar y, en concreto, las relativas a la sustracción ilícita de menores. De hecho, con todos los matices, y demoras, en comparación con lo ocurrido en los países anglosajones ${ }^{141}$, la UE encuentra hoy en la promoción del instituto de la mediación uno de sus signos distintivos en el ámbito de la integración jurídica ${ }^{142}$.

44. En sincronía con todo ello, el artículo 81 TFUE atribuye un relevante papel a los MASC en el seno del espacio jurídico europeo. Así, y tal como afirma el numeral 1 del precepto, la Unión desarrollará una cooperación judicial en asuntos civiles con repercusión transfronteriza, basada en el principio de reconocimiento mutuo de las resoluciones judiciales "y extrajudiciales". Pudiendo incluir esta cooperación la adopción de medidas de aproximación de las disposiciones legales y reglamentarias de los Estados miembros. Lo que se traduce, "en particular", cuando ello resulte necesario para el buen funcionamiento del mercado interior, y tal y como precisa el numeral 2 del artículo 81, en la adopción de medidas que garanticen, entre otros, "a) el reconocimiento mutuo, entre los Estados miembros, de las resoluciones judiciales y extrajudiciales, así como su ejecución; b) la notificación y el traslado transfronterizos de documentos judiciales y extrajudiciales; ..." o "g) el desarrollo de métodos alternativos de resolución de litigios".

45. Si bien el punto trigésimo de las Conclusiones del Consejo Europeo de Tampere del 15 y 16 de octubre de 1999, apuntaba ya, de forma global, de la necesidad, con vistas a lograr un "mejor acceso a la justicia en Europa", de que "Los Estados miembros deberían instaurar... procedimientos extrajudiciales alternativos" "143. La acción de la UE en el ámbito de los MASC se ha focalizado, significativamente, en la mediación, dejando de lado por motivos diversos al arbitraje ${ }^{144}$.

46. En relación con aquella, la publicación del Libro Verde sobre modalidades alternativas de solución de conflictos en el ámbito civil y mercantil de $2002^{145}$ constituyó la base sobre la que se asentará la posterior promulgación de la Directiva 2008/52/CE, sobre ciertos aspectos de la mediación en asuntos civiles y mercantiles ${ }^{146}$. Un texto que articula un conjunto de principios mínimos en

${ }^{141}$ En relación con ello, nótese, S. BARONA VILAR, Mediación en asuntos civiles y mercantiles en España. Tras la aprobación de la Ley 5/2012, de 6 de julio,, Valencia, Tirant lo Blanch, 2013, p. 32 y ss.; S. BARONA VILAR, Nociones y principios de las ADR (Solución jurisdiccional de conflictos), Valencia, Tirant lo Blanch, 2018, p. 17 y ss.

${ }^{142}$ Vid. en este sentido G. Palao Moreno, "La mediación y su codificación en Europa: aspectos de derecho internacional privado), en J.L. Gómez Colomer, S. Barona Vilar y P. Calderón Cuadrado (Coords.), El Derecho Procesal del Siglo XX a golpe de tango. Juan Montero Aroca. Liber Amicorum, en homenaje y para celebrar su LXX cumpleaños, Valencia, Tirant lo Blanch, 2012, pp. 1337-1338. Quien resalta el anclaje de esta actitud en el decidido apoyo que el Consejo de Europa prestó en su momento a la mediación (Ibid., p. 1342).

${ }^{143} \mathrm{https}$ //www.europarl.europa.eu/summits/tam_es.htm. Nótese al respecto, A. YBARRA Bores, "Mediación familiar internacional y Unión Europea: últimos avances", en M. Di Filippo, B. Campuzano Díaz, A. Rodríguez Benot et al (Coords.), Hacia un Derecho conflictual europeo: realizaciones y perspectivas, Sevilla, Universidad de Sevilla, 2008, pp. 223-225.

${ }^{144}$ Nótese, C. Esplugues, "International Commercial Arbitration in the EU and the PRC: A tale of Two Continents or 28 + 3 Legal Systems”, en J. BASEdow y K.B. Pissler (Eds.), Private International Law in Mainland China, Taiwan and Europe, Tubinga, Mohr Siebeck, 2014, pp. 409-413. En relación con la interacción del marco normativo internacional y europeo, considérese, P. QuinzÁ Redondo, "El arbitraje comercial internacional y los instrumentos de Bruselas: (re)pensando sobre su compleja relación", en S. Barona VILAR (Ed.), Psicoanálisis del arbitraje, cit., pp. 409-414.

${ }^{145}$ COM (2002) 196 final. Vid. R. AdAmo, A. Frosina y G. Triolo, “Civil Justice in matrimonial matters”, cit., pp. 165-168.

${ }^{146}$ DO L 136, de 24.5.2008. 
relación con ciertos aspectos, no todos, de la mediación transfronteriza en materia civil y mercantil en Europa ${ }^{147}$.

47. Adicionalmente, en el marco de esta situación de apoyo al uso de la mediación como forma de resolución de las disputas civiles y comerciales en Europa, se han promulgado por la Unión Europea diversos instrumentos que, si bien no aparecen directamente referidos a la institución, sí la prevén, amparan y fomentan, a través, habitualmente de una mención global a los MASC ${ }^{148}$. Instrumentos europeos dirigidos, esencialmente, al sector del consumo ${ }^{149}$, al de las telecomunicaciones ${ }^{150}$, al comercio electrónico $^{151}$ y las comunicaciones electrónicas ${ }^{152}$, a las marcas europeas ${ }^{153}$.

O, también, como no podía ser de otra forma, al Derecho de Familia. Una temática de especial complejidad y dinamismo en el momento actual ${ }^{154}$ que, a la vez, se presenta como el sector donde de forma más activa se reconoce la potencialidad e importancia del uso de la mediación ${ }^{155} \mathrm{y}$ en el que nos

${ }^{147}$ Vid., C. Esplugues, "Civil and Commercial Mediation in the EU After the Transposition of Directive 2008/52/EC", en C. Esplugues (Ed.), Civil and Commercial Mediation in Europe. Cross Border Mediation Cambridge, intersentia, 2014, pp. 488-517.

${ }^{148} \mathrm{Al}$ respecto, vid. G. Palao Moreno, "La mediación y su codificación en Europa", cit., pp. 1344-1345.

${ }^{149}$ Nótese la Directiva 2013/11/UE del Parlamento Europeo y del Consejo, de 21.5.2013, relativa a la resolución alternativa de litigios en materia de consumo y por la que se modifica el Reglamento (CE) n ${ }^{\circ}$ 2006/2004 y la Directiva 2009/22/CE (Directiva sobre resolución alternativa de litigios en materia de consumo), DO L 165, de 18.6.2013. O el Reglamento (UE) $n^{\circ}$ 524/2013 del Parlamento Europeo y del Consejo, de 21.5.2013, sobre resolución de litigios en línea en materia de consumo y por el que se modifica el Reglamento (CE) n 2006/2004 y la Directiva 2009/22/CE, DO L 165, de 18.6.2013.

${ }^{150}$ Nótese la Directiva (UE) 2018/1972 del Parlamento Europeo y del Consejo de 11.12.2018, por la que se establece el Código Europeo de las Comunicaciones Electrónicas (versión refundida), DO L 321 de 17.12.2018, cuyo art. 26.2 afirma que reconoce a los Estados miembros capacidad para disponer que la autoridad nacional de reglamentación "decida no resolver un litigio cuando existan otros mecanismos, como la mediación" que puedan contribuir mejor a resolver el litigio de manera oportuna y conforme a los objetivos enunciados en el art. 3 de la propia Directiva, informando la autoridad nacional de reglamentario de ello a las partes sin demora.

${ }^{151}$ Directiva 2000/31/CE del Parlamento Europeo y del Consejo, de 8.6.2000, relativa a determinados aspectos jurídicos de los servicios de la sociedad de la información, en particular el comercio electrónico en el mercado interior (Directiva sobre el comercio electrónico), DO L 178, de 17.7.2000, cuyo art. 17, intitulado "Solución extrajurisdiccional de litigios" recoge en su apartado 1, la obligación que acompaña a los Estados miembros de velar porque en caso de desacuerdo entre un prestador de servicios de la sociedad de la información y el destinatario del servicio, su legislación no obstaculice la utilización de los mecanismos de solución extrajudicial, existentes con arreglo a la legislación nacional para la solución de litigios, incluso utilizando vías electrónicas adecuadas. En tal sentido, y de acuerdo con su apartado 2, los Estados miembros alentarán a los órganos responsables de la solución extrajudicial de litigios, en particular de litigios en materia de productos de consumo, a que actúen de modo tal que proporcionen garantías de procedimiento adecuadas a las partes afectadas incitándoles, también, de acuerdo con su apartado 3, a que informen a la Comisión de las decisiones relevantes que tomen en relación con los servicios de la sociedad de la información, y a que le transmitan todos los demás datos sobre prácticas, usos o costumbres relacionados con el comercio electrónico.

${ }^{152}$ Directiva (UE) 2018/1972 del Parlamento Europeo y del Consejo, de 11.12.2018, por la que se establece el Código Europeo de las Comunicaciones Electrónicas (versión refundida), DO L 321, de 17.12.2018, cuyo art. 25, rubricado "Resolución extrajudicial de litigios", compele -en su apartado 1- a los Estados miembros a velar porque las autoridades nacionales de reglamentación u otra autoridad competente responsable de la aplicación de los arts. 102 a 107 y 115 de la Directiva, o al menos un "organismo independiente con probada experiencia en este ámbito", aparezcan en una lista de entidades alternativas para la resolución de conflictos de conformidad con el mandato del art. 20.2 de la Directiva 2013/11/UE con el fin de resolver los litigios entre proveedores y consumidores que se deriven de la presente Directiva 2018/1972 y relativos a la ejecución de contratos. Permitiéndose a los Estados miembros extender el acceso a los procedimientos alternativos de resolución de conflictos proporcionados por dicha autoridad u organismo a los usuarios finales que no sean consumidores, en particular microempresas y pequeñas empresas. En aquellas ocasiones en que tales litigios afecten a partes de diferentes Estados miembros, los Estados miembros quedan obligados, al amparo del apartado 2 del precepto, a coordinar sus esfuerzos "en aras de una resolución del litigio". A su vez, el art. 26.2 precisa que "Los Estados miembros podrán disponer que la autoridad nacional de reglamentación decida no resolver un litigio cuando existan otros mecanismos, como la mediación, que puedan contribuir mejor a resolver el litigio de manera oportuna y conforme a los objetivos enunciados en el artículo 3."

${ }^{153}$ Reglamento (UE) 2017/1001 del Parlamento Europeo y del Consejo, de 14.6.2017, sobre la marca europea, DO L 154, de 16.6.2017, arts. 151.4 y 170 (y Considerando 35). Nótese al respecto, https:/euipo.europa.eu/ohimportal/es/mediation.

${ }^{154} \mathrm{Al}$ respecto, y por todos, vid. R. Espinosa CAlabuig, Custodia y visita de menores en el espacio judicial europeo, Madrid, Marcial Pons, 2007, pp. 19-37.

${ }^{155}$ Vid. C. Esplugues y J.L. Iglesias, "Mediation and Private International Law: Improving Free Circulation of Mediation Agreements Across the EU", en The Implementation of the Mediation Directive 29 November 2015. Compilation of In-depth Analysis (European Parliament - Directorate-General for Internal Policies), Brussels, 2016, pp. 73 y 80; Comisión EurOPEA, 
vamos a focalizar. Si bien atendiendo el ámbito material de la Directiva -se excluyen aquellos derechos y obligaciones que no estén a disposición de las partes en virtud de la legislación pertinente de acuerdo con su artículo 1.2- se apoya por algunos que "it does not apply, in principle, to matters of parental responsibility" ${ }^{156}$. Lo cierto es que el significado de disponibilidad varía de país a país en la UE ${ }^{157}$, con un impacto directo en la mediación transfronteriza, y el propio Consejo de la Unión, en 2010, procede a invitar a los "Member States to consider the particular issue of child abduction during the transposition and /or the implementation of the Directive 2008/52/CE of the European Parliament and of the Council of 21 May 2008 on certain aspects of the mediation in civil and commercial matters"158.

48. En este sentido, el propio Parlamento Europeo, que, como hemos señalado, ya en 1987 había creado la figura del "mediador del Parlamento Europeo para Casos de Sustracción Internacional de Menores" ${ }^{159}$, abogará en su ya apuntada Resolución de 12 de septiembre de 2017 por utilizar todas las herramientas disponible para "aumentar la tasa de utilización de la mediación familiar en contextos transfronterizos, en particular en caso de sustracción de menores" ${ }^{\prime 60}$. Máxime si se toma en consideración la especial complejidad que estas situaciones presentan en cuanto a su contenido y resolución. A lo que se añade, en muchas ocasiones, la falta de especialización de los operadores jurídicos que conocen de estas cuestiones ${ }^{161}$.

\section{La Directiva 2008/52/CE como clave de bóveda del modelo europeo de mediación en materia civil y mercantil}

49. La Directiva 2008/52/CE ha tenido la virtud de servir para colocar a la institución en la agenda legislativa europea, y, también, en la de muchos Estados miembros. Favoreciendo, igualmente, la exploración de su uso en una pluralidad de sectores novedosos dentro y fuera del ámbito estricto de la materia civil y mercantil ${ }^{162}$ : desde discriminación por razón de género ${ }^{163}$, al comercio internacional ${ }^{164} \mathrm{o}$ la licitación pública ${ }^{165}$, entre otros. Sin embargo, lo cierto es que no ha generado una respuesta normativa unitaria en relación con la figura, en el seno de la Unión. La transposición de la Directiva sobre media-

Informe de la Comisión Europea al Parlamento Europeo, al Consejo y al Comité Económico y Social Europeo sobre la aplicación de la Directiva 2008/52/CE del Parlamento Europeo y del Consejo sobre ciertos aspectos de la mediación en asuntos civiles y mercantiles, Bruselas, 26.8.2016, COM(2016) 542 final, pp. 2 y 5. Igualmente, Сн. C. PAul, "The Role of Family Mediation", cit., pp. 18-19. Un análisis global de la situación existente en Europa en esta materia se encuentra en, M. INFANTINO, "Family Mediation. A Comparative Survey", en A. Miranda (Ed.), Mediation in Europe, cit., p. 189 y ss. En relación con el recurso a la mediación familiar en Europa, nótese, igualmente, M. MARTIN CASALS, "Divorce Mediation in Europe: An Introductory Outline", Electronic Journal of Comparative Law, vol. 9.2, 2005, p. 3 y ss.

${ }^{156}$ L. DE Lima Pinheiro, "Article 55: Cooperation on Cases Specific to Parental Responsibility”, en U. Magnus y P. ManKOWSKI (Eds.), Brussels II bis Regulation, Munich, Sellier, 2012, p. 418.

${ }^{157}$ De hecho, la desacorde transposición en los diversos Estados de la Unión ha conducido a una interpretación diversa de su ámbito material. Vid., al respecto, C. Esplugues, "Civil and Commercial Mediation", cit., pp. 739-740.

${ }^{158}$ Council of the European Union, Conclusions of the ministerial, cit., p. 6.

${ }^{159}$ Vid. $n^{\circ} 35$. En relación con su funcionamiento vid., Parlamento Europeo, Mediador del Parlamento Europeo para casos de sustracción internacional de menores. Vademécum, Estrasburgo, Parlamento Europeo (disponible en: https://www. europarl.europa.eu/pdf/mediator_children/Child_abduction_handbook_es.pdf).

${ }^{160}$ Parlamento Europeo, Resolución del Parlamento Europeo, de 12 de septiembre de 2017, cit., Conclusión principal (8).

${ }^{161} \mathrm{Al}$ respecto, C. GonzÁlez Beilfuss, "La mediación en los conflictos familiares internacionales", en E. LaURoBa LaCASA, I. Barrals Viñals e I. Viola Demestre (Coords.), Materiales jurídicos del Libro Blanco de la Mediación en Cataluña, Barcelona, Generalitat de Cataluña, 2011, p. 228.

${ }^{162}$ Nótese, European Commission: The 2020 EU Justice Scoreboard, Publications Office of the European Union, Luxembourg, 2020, p. 28 .

${ }^{163}$ FRA - European Union Agency for Fundamental Rights: Access to Justice in Europe: An Overview of Challenges and Opportunities, Viena, FRA, 2010, pp. 45-46.

${ }^{164}$ Vid., por ejemplo, el art. 8.20 -"Mediación”- del Acuerdo Económico y Comercial Global (CETA) entre Canadá, por una parte, y la Unión Europea y sus Estados miembros, por otra, DO L 11, de 14.1.2017.

165 "Siempre se deberán contemplar las soluciones de mediación" (COMISIÓn EuropeA, Contratación pública. Guía práctica sobre cómo evitar los errores más comunes en la contratación pública de proyectos financiados con cargo a los Fondos Estructurales y de Inversión Europeos, Luxemburgo, Oficina de Publicaciones, 2015, p. 36). 
ción, como el mismo Parlamento Europeo ha reconocido ${ }^{166}$, ha sido altamente desigual en los distintos Estados miembros de la UE, generando respuestas muy variadas en ellos, y favoreciendo la subsistencia de notables diferencias entre sus legislaciones ${ }^{167}$.

\section{A) Una transposición con claroscuros}

50. Los resultados obtenidos tras la transposición son ambivalentes, y no parece que se haya logrado una generalización del recurso a la mediación en el ámbito de los litigios civiles y comerciales, en los que su utilización sigue resultando marcadamente marginal en la Unión; especialmente en relación con las disputas comerciales transfronterizas ${ }^{168}$. Se admite que, efectivamente, la Directiva "ha aportado valor añadido a la UE"169. Sin embargo, aun siendo "extremadamente importante en lo relativo a la creación y el recurso al procedimiento de mediación en la Unión" se constata, como apunta el Parlamento Europeo en su Resolución de 12 de septiembre de 2017, que "su aplicación ha variado considerablemente en función del Estado miembro, dependiendo en la existencia anterior o no de sistemas nacionales de mediación" ${ }^{170}$. Lo que se traduce, en última instancia, en la persistencia de dificultades en el funcionamiento práctico de los sistemas nacionales de mediación. En muchos casos vinculados al desconocimiento de la institución, y a la ausencia de una "cultura" de mediación en los Estados de la Unión, que se ven acentuados al tratar casos transfronterizos ${ }^{171}$. O, en última instancia, relacionados con la diversidad de culturas jurídicas de los distintos ordenamientos jurídicos nacionales ${ }^{172}$.

51. Debido a la propia naturaleza confidencial que acompaña a la figura ${ }^{173}$, no existen datos estadísticos completos y fiables en la materia; ni sobre las mediaciones realizadas ni, tampoco, sobre su duración o los porcentajes de éxito ${ }^{174}$. En todo caso, a comienzos de la década pasada, se hablaba de una horquilla de entre el $0,5 \%$ y el $2 \%$ de disputas comerciales sometidas a mediación. Cifra que se veía reducida hasta un exiguo $0,05 \%$ en el caso de los litigios transfronterizos. Además, la trascendencia de estas negativas cifras se veía gravemente agudizada al afirmarse que cerca de un $25 \%$ del total de disputas comerciales surgidas en Europa quedaban huérfanas de solución ante el rechazo de los afectados a litigar ${ }^{175}$.

52. En definitiva, se confirma lo que gráficamente se ha denominado como la "paradoja" de la actual situación de la mediación en Europa: "as there are great success rates (documented high success rate percentages) coming from disputants who engaged in mediation in specific cases, but these suc-

\footnotetext{
${ }^{166}$ Parlamento Europeo, Resolución del Parlamento Europeo, de 12 de septiembre de 2017, cit., Considerando A.

${ }^{167}$ Vid. C. Esplugues, "Civil and Commercial Mediation”, cit., pp. 519-527. Considérese, igualmente, European CommissIon, Study for an Evaluation and Implementation of Directive 2008/52/EC - the 'Mediation Directive' Final Report, Brussels, Directorate-General Justice and Consumers, Directorate A - Civil Justice, Unit A1 - Civil Justice Policy, 2016, pp. 30-45.

${ }^{168}$ Nótese, C. Azcárraga Monzonís, "El (limitado) impacto de la directiva sobre mediación en asuntos civiles y mercantiles y la mediación obligatoria como medida de promoción", en S. BARONa VILAR (Coorda.), Mediación, arbitraje y jurisdicción en el actual paradigma de justicia, Madrid, Thomson Reuters-Civitas, 2016, p. 105 y ss.

${ }^{169}$ Comisión Europea, Informe de la Comisión Europea, cit., p. 3.

${ }^{170}$ Parlamento Europeo, Resolución del Parlamento Europeo, de 12 de septiembre de 2017, cit., p. 3, letra A.

${ }^{171}$ Comisión Europea, Informe de la Comisión Europea, cit., p. 4.

${ }^{172}$ Parlamento Europeo, Resolución del Parlamento Europeo, de 12 de septiembre de 2017, cit., Considerando C.

${ }^{173}$ Y que, recordemos, reconoce de forma explícita el art. 7 (y el Considerando 23) de la Directiva 2008/52/CE.

${ }^{174}$ Este es, precisamente, uno de los principales lamentos que formula el Parlamento Europeo en su Resolución de 12.9.2017 (cit., Conclusiones principales, 6), apuntando que "sin una base de datos fiable, resulta muy dificil seguir fomentando la mediación y aumentar la confianza de la opinión pública en su eficacia" (Ibid.). Lo que le llevaba a pedir a la Comisión que como a facilitar datos estadísticos relevantes exhaustivos (Recomendaciones, 15). Con respecto a los porcentajes de éxito, vid. algunas cifras en European Commission, Study for an Evaluation, cit., p. 69.

${ }^{175}$ V. Tilman, Lessons Learnt from the Implementation of the EU Mediation Directive: The Business Perspective, Brussels, Directorate General for Internal Policies. Policy Department C: Citizens' Rights and Constitutional Affairs, Legal Affairs, 2011, p. 4 (http://www.europarl.europa.eu/document/activities/cont/201105/20110518ATT19584/20110518ATT19584EN.pdf).
} 
cesses are extremely limited in number. The paradox is that while the use of mediation yields highly successful results, it (mediation) is rarely used in a systematic way by disputants and lawyers" ${ }^{\text {"176. }}$.

53. La Directiva y su transposición no parece haber acelerado el necesario "cambio de mentalidad en lo jurídico, mediante la adopción de una cultura de la mediación y la resolución amistosa de conflictos" 177 en la sociedad europea. Dando génesis a un proceso que permita alcanzar esa "relación equilibrada entre la mediación y el proceso judicial" a la que refiere el artículo 1.1 del texto de 2008, atendido el hecho de que, en la mayoría de los Estados miembros, "la mediación se utiliza en menos del $1 \%$ de los casos llevados ante los tribunales" ${ }^{178}$. Lo que demuestra, en suma, que "is far from being solidly established in Europe" ${ }^{\prime 179}$.

54. Estos números, lamentablemente, no son mucho mejores en España, donde la ausencia de datos estadísticos sobre las eventuales mediaciones extraprocesales se acompañan de unas cifras claramente marginales en el supuesto de las mediaciones intraprocesales. Ciertamente, el propio Consejo General del Poder Judicial (CGPJ) ha fomentado desde antiguo el recurso a la figura ${ }^{180}$. Una posición que queda reflejada, recientemente y entre otras medidas, en la elaboración, en enero de 2020, de las "Diez acciones imprescindibles para una justicia justa" 181 . O en la aprobación por el pleno del CGPJ, el 16 de junio de 2020, del "Plan de choque del CGPJ para la reactivación tras el estado de alarma"182 que incorpora, dentro de los "Principios generales de las propuestas de reforma normativa", el objetivo de lograr la necesaria mitigación del exceso de litigiosidad, mediante, entre otros mecanismos, "El fomento de la mediación intrajudicial" y "La potenciación de los mecanismos para la solución extrajudicial de conflictos" 183 . Una meta que, añade, requerirá, entre otros pasos, favorecer la "mayor implicación posible" en este ámbito de todos aquellos operadores jurídicos e intervinientes en los procesos que puedan coadyuvar, junto con los jueces y magistrados, al fomento de la mediación y la búsqueda de acuerdos ${ }^{184}$.

55. Sin embargo, lo cierto es que el uso de la mediación como forma de resolver las disputas civiles y comerciales en nuestro país sigue siendo extremadamente limitado. Se celebra por parte del CGPJ, por ejemplo, el incremento de los órganos jurisdiccionales que derivan a mediación (más de 700, de los que 253 derivan a mediación familiar, 250 a mediación penal, 111 a mediación civil, más las experiencias en lo contencioso y en lo social), y el mayor compromiso de la carrera judicial con la ins-

${ }^{176}$ G. De Palo, A. Feasley y F. Orecchini, Quantifying the cost, cit., p. 10.

177 Parlamento Europeo, Resolución del Parlamento Europeo, de 12 de septiembre de 2017, cit., Considerando C.

${ }^{178}$ Parlamento Europeo, Resolución del Parlamento Europeo, de 12 de septiembre de 2017, cit., Considerando F.

${ }^{179}$ G. De Palo, A. Feasley y F. Orecchini, Quantifying the cost, cit., p. 9.

$180 \mathrm{Vid}$. https://www.poderjudicial.es/cgpj/es/Temas/Mediacion/. Nótese, a su vez, CGPJ, Comunicado del CGPJ en el Día Europeo de la Mediación. El órgano de gobierno de los jueces reitera su compromiso para seguir impulsando la mediación como medio alternativo de resolución de controversias, de 21.1.2021 (disponible en: https://www.poderjudicial.es/cgpj/es/ Poder-Judicial/En-Portada/Comunicado-del-CGPJ-en-el-Dia-Europeo-de-la-Mediacion) y A. GARCÍA Herrera, "Reestructuración de la familia tras la separación parental: mediación intrajudicial, mediación en el punto de encuentro familiar y coordinación de parentalidad", InDret, 2016-2, pp. 9-10.

${ }^{181}$ En el que se habla, entre otros extremos, del fomento de la mediación de resolución de conflictos, implantando la mediación intrajudicial "como derecho del Ciudadano a optar por el mecanismo más adecuado a la Solución de su Conflicto" favoreciendo la difusión, conocimiento y educación "en mediación" de "todos los implicados en la resolución de conflictos y a la ciudadanía porque la mediación mejora la experiencia de justicia" (p. 2) (Disponible en: https:/www.poderjudicial.es/ stfls/CGPJ/MEDIACI\%C3\%93N/FICHERO/20200122\%20Diez\%20acciones\%20imprescindibles\%20para\%20una\%20justicia\%20justa.pdf).

${ }_{182}$ Disponible en: https://www.poderjudicial.es/stfls/SALA\%20DE\%20PRENSA/DOCUMENTOS\%20DE\%20INTERES/ Plan\%20de\%20choque\%20aprobado\%20por\%20el\%20Pleno\%20del\%20CGPJ\%20el\%2016\%20de\%20junio\%20de\%202020. pdf. Nótense, igualmente, el Anexo fichas medidas plan de choque del CGPJ, disponible en: https://www.poderjudicial.es/stfls/ SALA\%20DE\%20PRENSA/DOCUMENTOS\%20DE\%20INTERES/Anexo\%20fichas\%20medidas\%20plan\%20de \%20choque $\% 20$ del\%20CGPJ.pdf.

${ }^{183}$ CGPJ, "Plan de choque", cit., p. 3.

184 "muy especialmente" se dice, "la Abogacía, pero también los fiscales, letrados de la administración de justicia, notarios, registradores, equipos psicosociales de los juzgados, oficinas de atención a las víctimas, policía judicial...", CGPJ, "Plan de choque", cit., p. 9. 
titución ${ }^{185}$. Pero lo anterior contrasta con unas cifras de uso extraordinariamente reducidas. Las estadísticas del propio CGPJ hablan de 2348147 nuevos asuntos civiles y mercantiles ingresados en 2019, con 2245773 resueltos, y 1564183 en trámite al final del año ${ }^{186}$. Y, en claro contraste con estas magnitudes, de tan sólo 4769 casos derivados a mediación familiar, con 553 finalizados con avenencia y 2688 sin ella. Así como de 1073 casos civiles referidos a mediación, con 143 finalizados con avenencia y 545 sin avenencia ${ }^{187}$. Lo que supone, un total de 5842 derivados (un insignificante $0.026 \%$ del global de asuntos resueltos) y 696 casos finalizados con avenencia. Unas magnitudes que, como se observan, no pueden resultar más desoladoras, y que reflejan en toda su crudeza la condición marginal de la mediación, y su naturaleza presente de "tema de futuro", de mera "promesa"188.

\section{B) La limitada circulación en el seno de la UE de los acuerdos alcanzados en el marco de una me- diación}

56. La limitada extensión del ámbito material de la Directiva y su falta de audacia en ciertos puntos ha tenido un impacto directo en algunos extremos muy sensibles para la consolidación de la figura como alternativa, o complemento, real a los tribunales estatales en el territorio de la Unión Europea. La cuestión de la posible circulación de los eventuales acuerdos alcanzados en el marco de un procedimiento de mediación en un Estado miembro en el territorio de la Unión es, sin lugar a dudas, uno de ellos ${ }^{189}$.

57. La Directiva incorpora un artículo 6, rubricado "Carácter ejecutivo de los acuerdos resultantes de la mediación", en cuyo apartado 1 se establece que los "Estados miembros garantizarán que las partes, o una de ellas con el consentimiento explícito de las demás, puedan solicitar que se dé carácter ejecutivo al contenido de un acuerdo escrito resultante de una mediación". Sin embargo, el propio precepto reconoce la realidad de la situación existente en Europa, en la que de forma prácticamente unánime, y a diferencia de lo que ocurre en otras latitudes -especialmente Iberoamérica- donde gozan generalizadamente de efectos ejecutivos, atribuyéndoseles incluso la condición de cosa juzgada ${ }^{190}$, los acuerdos concluidos en el marco de una mediación, cuentan mayoritariamente con una naturaleza puramente contractual ${ }^{191}$. Lo que supone que requerirán de una previa homologación por parte de ciertas autoridades públicas -judiciales y no judiciales- para adquirir fuerza ejecutiva ${ }^{192}$.

58. En tal sentido, el propio artículo 6.2 no duda en añadir que el "contenido del acuerdo" podrá adquirir carácter ejecutivo en virtud de "sentencia, resolución o acto auténtico emanado de un órgano jurisdiccional u otra autoridad competente", de acuerdo con la legislación del Estado miembro en que se formule la solicitud. Destacándose en el apartado 1 del artículo, que el contenido del eventual acuerdo concluido por las partes en el marco de la mediación "se hará ejecutivo a menos que, en el caso de que

${ }^{185}$ CGPJ, Comunicado del CGPJ, cit.

${ }^{186}$ CGPJ, La Justicia dato a dato. Año 2019. Estadística judicial, Madrid, CGPJ, 2019, p. 36.

${ }^{187}$ CGPJ, Mediación intrajudicial - Años 2009-2019 (disponible en: https://www.poderjudicial.es/stfls/ESTADISTICA/ FICHEROS/14003\%20Mediacion\%20Intrajudicial/Mediaci\%C3\%B3n/Mediacion\%20intrajudicial.xls).

${ }^{188}$ U. Rondón, "Introducción”, en Estado de la mediación en España, Abril 2018 (Universidad de Murcia y Federación Nacional de Asociaciones de Profesionales de la Mediación, Eds.), Murcia, 2018, p. 3 (disponible en https://docplayer. es/83848070-Estado-de-la-mediacion-en-espana-abril-2018-elaborado-por.html).

${ }^{189}$ C. Esplugues, "Civil and Commercial Mediation”, cit., p. 761 y ss. Una cuestión que, significativamente, se reproduce en otros ámbitos geográficos, nótese en este sentido, C. Esplugues, “General Report: New Developments in Civil and Commercial Mediation - Global Comparative Perspectives", en C. Esplugues y L. MARQuis (Eds.), New Developments in Civil and Commercial Mediation, Heidelberg, Springer, 2015, p. 80.

${ }^{190}$ Nótese C. Esplugues Mota, Mediación civil y comercial, cit., pp. 326-336.

${ }^{191}$ Considérese en este sentido, K.J. Hopt y F. STEFFEK, "Mediation: Comparison of Laws, Regulatory Models, Fundamental Issues", en K.J. Hopt y F. Steffek (eds.), Mediation Principles and Regulation in Comparative Perspective, Oxford, OUP, 2013 , p. 46.

${ }^{192}$ Un análisis comparado de la situación existente en Europa se encuentra en, C. EspLuguEs, "Civil and Commercial Mediation", cit., pp. 717-727. 
se trate, bien el contenido de ese acuerdo sea contrario al Derecho del Estado miembro donde se formule la solicitud, bien la legislación de ese Estado miembro no contemple su carácter ejecutivo".

59. La homologación del acuerdo por parte de una autoridad pública, generalmente un juez o un notario, implica contar, como avanza el ya mencionado apartado 2 del artículo 6 de la Directiva, con una resolución judicial homologando el acuerdo o un documento público que lo recoja ${ }^{193}$ que, en consonancia con el apartado 4 del artículo 6 de la Directiva, circularán en la Unión atendiendo a lo dispuesto en los distintos instrumentos europeos en materia de reconocimiento y ejecución ${ }^{194}$.

60. Ello se traduce, en suma, como admiten los propios Considerandos 20 y 21 de la Directiva, en que los eventuales acuerdos alcanzados en el seno de un procedimiento de mediación en algún Estado de la Unión circularán en el territorio de ésta -"debe ser reconocido y declarado ejecutivo en los demás Estados miembros" 195 dice-, cuando "hayan adquirido carácter ejecutivo en un Estado miembro"196 de conformidad con la legislación europea -siempre que se incardinen en el ámbito material de alguno de los instrumentos europeos de DIPr susceptibles de ser aplicables en este ámbito ${ }^{197}$-. o de acuerdo con la legislación nacional aplicable. En este sentido, por ejemplo, y como excepción a la regla general europea, la normativa portuguesa reconoce efectos directos en el país a "o acordo de mediação obtido por via de mediação realizada noutro Estado membro da União Europeia que respeite o disposto nas alíneas a) e d) do n. $^{\circ} 1$, se o ordenamento jurídico desse Estado também lhe atribuir força executiva" ${ }^{\prime 198}$.

61. Si bien, como reconoce el propio Considerando 20 de la Directiva, el elenco de textos europeos es muy amplio, la respuesta ofrecida no resulta plenamente satisfactoria en lo relativo a sus resultados, previsibilidad y costes. Una posición constatada por el Parlamento Europeo en su Resolución de 12 de septiembre de $2017^{199}$, que considera que esta exigencia de homologación origina costes adicionales, es lenta para las partes del acuerdo y, puede "afectar negativamente a la circulación de acuerdos de mediación extranjeros, especialmente en el caso de litigios menores" ${ }^{200}$. Y que ha llevado a la propia Unión a plantearse reformar la Directiva, al menos su artículo 6, con vistas a fomentar la circulación de estos acuerdos en el seno de la UE ${ }^{201}$.

\section{Los Reglamentos Bruselas II bis y ter y el recurso a la mediación y otras formas de resolución amistosa de litigios}

62. En este entorno de cierta decepción con los resultados de la transposición de la Directiva 2008/52/CE, la evaluación del impacto de su puesta en práctica ha mostrado al Derecho de familia como aquel ámbito en el que, en el actual momento de futuro en construcción para la mediación que se vive en la UE, la institución refleja un nivel de conocimiento, potencialidad y presencia más amplio; superior, en todo caso, al existente en otros muchos sectores civiles y mercantiles en los distintos países de la Unión $^{202}$. Con una especial potencialidad, como seguidamente veremos, en relación con la responsabilidad parental y la sustracción de menores ${ }^{203}$.

\footnotetext{
${ }^{193}$ Art. 6.2 Directiva 2008/52/CE.

${ }^{194}$ Vid. C. Esplugues, "Civil and Commercial Mediation”, cit., pp. 730-735.

${ }^{195}$ Considerando 20 Directiva 2008/52/CE.

${ }^{196}$ Considerando 20 Directiva 2008/52/CE.

${ }^{197}$ Vid. C. Esplugues, "Civil and Commercial Mediation”, cit., pp. 763-766.

${ }^{198}$ Art. 9.4, Lei n. ${ }^{\circ}$ 29/2013 de 19 de abril. Estabelece os princípios gerais aplicáveis à mediação realizada em Portugal, bem como os regimes jurídicos da mediação civil e comercial, dos mediadores e da mediação pública, DRE n. ${ }^{\circ} 77 / 2013$, Série I de 19.4.2013. Nótese al respecto, C. Esplugues, “General Report”, cit., pp. 78-80.

${ }^{199}$ Cit., nota 30 supra.

${ }^{200}$ Parlamento Europeo, Resolución del Parlamento Europeo, de 12 de septiembre de 2017, cit., Conclusión principal (10).

${ }^{201}$ Vid. C. Esplugues y J.L. Iglesias, "Mediation and Private International Law”, cit., p. 79 y ss.

${ }^{202}$ European Commission, Study for an Evaluation, cit., pp. 66 y 77; J. Tymowski, The Mediation Directive. European Implementation Assessment, Brussels, European Parliamentary Research Service, PE 593.789, December 2016, pp. 11, 14,17 ó 23.

203 J. TYMowski, The Mediation Directive, cit., p. 11.
} 
63. El recurso a la mediación, y a otros mecanismos de resolución alternativa de litigios, como vía de resolución de las controversias surgidas en el ámbito familiar se hace patente, de manera y con grados diversos, en algunos de los Reglamentos existentes en este ámbito temático ${ }^{204}$. Así, el Reglamento (CE) $n^{\circ} 4 / 2009$ del Consejo, de 18 de diciembre de 2008 , relativo a la competencia, la ley aplicable, el reconocimiento y la ejecución de las resoluciones y la cooperación en materia de obligaciones de alimentos ${ }^{205}$ apunta en su artículo 51.2 que las autoridades centrales tomarán las medidas que estimen apropiadas en relación con el cobro de alimentos al amparo del artículo 56 del mencionado texto reglamentario. Resaltando, entre ellas la de "d) promover las soluciones amistosas a fin de obtener el pago voluntario de los alimentos, recurriendo cuando sea apropiado a la mediación, la conciliación o mecanismos análogos".

64. Sin embargo, es en los Reglamentos Bruselas II bis y, ahora, en el Bruselas II ter, donde el legislador europeo ha manifestado con mayor nitidez su apuesta por el fomento de los mecanismos de resolución alternativa, o complementaria, de litigios para resolver unas disputas de carácter familiar-las relativas a la responsabilidad parental y a la sustracción de menores- que, por su propia naturaleza, y la especial sensibilidad -y grado diverso de disponibilidad- de los intereses involucrados, resultan especialmente complejas y sensibles.

\section{El Reglamento Bruselas II bis}

65. Así, en línea con lo que prevé el Reglamento en materia de alimentos, también el Reglamento (CE) $n^{\circ} 2201 / 2003$ del Consejo, de 27 de noviembre de 2003, relativo a la competencia, el reconocimiento y la ejecución de resoluciones judiciales en materia matrimonial y de responsabilidad parental, por el que se deroga el Reglamento (CE) $n^{\circ} 1347 / 2000^{206}$-el denominado Reglamento Bruselas II bis- recoge la posibilidad de cooperación de las autoridades centrales con vistas a explorar vías alternativas a los tribunales estatales en casos específicamente relacionados con la responsabilidad parental y la sustracción de menores ${ }^{207}$.

66. En este sentido, el Reglamento, en su artículo 55, menciona que, a petición de una autoridad central de otro Estado miembro, o de un titular de la responsabilidad parental, las autoridades centrales cooperarán en asuntos concretos, con el fin de cumplir los objetivos del texto reglamentario. Y, a tal efecto, adoptarán, ya sea de forma directa o a través de las autoridades públicas u otros organismos, todas las medidas adecuadas, con arreglo a la legislación de dicho Estado miembro en materia de protección de datos personales, con vistas a, entre otros objetivos, “e) facilitar la celebración de acuerdos entre los titulares de la responsabilidad parental a través de la mediación o por otros medios, y facilitar con este fin la cooperación transfronteriza" ${ }^{208}$ buscando facilitar el mencionado logro de los objetivos del Reglamento ${ }^{209}$.

\footnotetext{
${ }^{204}$ Esta referencia se echa a faltar en los Reglamento (UE) 2016/1103 del Consejo, de 24.6.2016, por el que se establece una cooperación reforzada en el ámbito de la competencia, la ley aplicable, el reconocimiento y la ejecución de resoluciones en materia de regímenes económicos matrimoniales, DO L 183, de 8.7.2016, en el Reglamento (UE) 2016/1104 del Consejo, de 24.6.2016, por el que se establece una cooperación reforzada en el ámbito de la competencia, la ley aplicable, el reconocimiento y la ejecución de resoluciones en materia de efectos patrimoniales de las uniones registradas, DO L 183, de 8.7.2016 o, aunque no se trata estrictamente de materia familiar, en el Reglamento (UE) n ${ }^{\circ}$ 650/2012 del Parlamento Europeo y del Consejo, de 4.7.2012, relativo a la competencia, la ley aplicable, el reconocimiento y la ejecución de las resoluciones, a la aceptación y la ejecución de los documentos públicos en materia de sucesiones mortis causa y a la creación de un certificado sucesorio europeo, DO L 201, de 27.7.2012.

${ }^{205}$ DO L 7, de 10.1.2009.

206 DO L 338, de 23.12.2003.

${ }^{207}$ Al respecto, vid. TH. KRUGER, "Enhancing Cross-Border Cooperation”, cit., p. 37 y ss. Igualmente, F.J. ForCADA MiranDA, Sustracción internacional de menores, cit., pp. 147-148.

${ }^{208}$ Vid. A. Hernández Rodríguez, "Mediación y secuestro internacional”, cit., p. 137.

${ }^{209}$ M. ŽupAN, "Chapter 10 Cooperation of Central Authorities", en C. HonORATI (Ed.), Jurisdiction in matrimonial matters, parental responsibility and abduction proceedings. A Handbook on the Application of Brussels IIa Regulation in National
} 
67. En línea con ello, y apuntando, a la vez, la conveniencia de que el recurso a la institución de la mediación -o a cualquier otro "medio" distinto de ésta que facilite la obtención de un acuerdo- no se realice con el objeto de retrasar indebidamente la restitución del menor, se resalta que, específicamente la mediación, se ha demostrado como un instrumento relevante y eficaz en relación con la sustracción de menores. Con vistas, por ejemplo, a lograr que el menor pueda continuar viendo a sus progenitores, incluido quien realizó la sustracción, después de su restitución al país de origen ${ }^{210}$.

68. Si bien el artículo 2.4 del Reglamento Bruselas II bis nada dice al respecto. El Considerando 22 del propio texto reglamentario, al definir la noción de "resolución judicial" 211 a efectos de la aplicación de las normas sobre reconocimiento y ejecución del Reglamento, afirma que tanto los documentos públicos como "los acuerdos entre las partes que sean ejecutivos en un Estado miembro deben asimilarse a "resoluciones judiciales"'. Acuerdos que, recordemos, pueden haberse alcanzado en el marco de una mediación o "por otros medios", tal como reconoce el apuntado artículo 55.e).

69. En línea con ello, el artículo 46 del Reglamento Bruselas II bis procede a reiterar que los "documentos públicos con fuerza ejecutiva formalizados o registrados en un Estado miembro, así como los acuerdos entre las partes que tengan fuerza ejecutiva en el Estado miembro de origen, serán reconocidos y se dotarán de fuerza ejecutiva en las mismas condiciones que las resoluciones judiciales".

70. El problema de fondo del modelo diseñado en el Reglamento Bruselas II bis respecto de los "acuerdos entre las partes que tengan fuerza ejecutiva en el Estado miembro de origen" estriba en el hecho mismo de la naturaleza atribuido a este tipo de acuerdos alcanzados por las partes en el marco de una mediación, o fuera de ella.

71. En relación en concreto con los acuerdos obtenidos en el seno de una mediación en Europa, la mayoría de los ordenamientos jurídicos europeos -ya se ha avanzado- les atribuyen una condición estrictamente contractual, careciendo de fuerza ejecutiva per $\mathrm{se}^{212}$. $\mathrm{Y}$, con muy escasas excepciones, se exige siempre su previa homologación por una autoridad pública, bien judicial o extrajudicial, para poder contar con tal naturaleza y efectos. Lo que conlleva su elevación a escritura pública, o su incorporación en una sentencia $\mathrm{o}$, incluso, eventual laudo ${ }^{213}$. Sin tal naturaleza ejecutiva, los acuerdos no serán susceptibles de beneficiarse del modelo de reconocimiento y ejecución diseñado en los distintos instrumentos europeos, y no podrán circular en el seno de la Unión al amparo de estos, dependiendo, por lo tanto, de las soluciones nacionales.

72. La exigencia de homologación del acuerdo alcanzado, ve acentuada su trascendencia por el hecho mismo de que al referir éste a la responsabilidad parental y a la sustracción, e involucrar a menores,

Courts, Torino / Frankfurt, Giappichelli y Peter Lang, 2017, p. 268-271; V. Lazić y W. Schrama, "Chapter 10: Cooperation between Central Authorities in Matters of Parental Responsibility”, en V. LAzić (Gen. Ed.), Regulation Brussels IIbis. Guide for Application, The Hague, Asser Institut, julio 2018, p. 284 y ss.

${ }^{210}$ Comisión Europea, Guía práctica para la aplicación del Reglamento Bruselas II bis, Bruselas, Oficina de Publicaciones, 2014 , p. 83 .

${ }^{211}$ Art. 2: “A los efectos del presente Reglamento, se entenderá por: ... d) resolución judicial, las resoluciones de divorcio, separación judicial o nulidad matrimonial y las relativas a la responsabilidad parental dictadas por un órgano jurisdiccional de un Estado miembro, independientemente de cómo se denomine dicha resolución, incluidos los términos de sentencia o auto". Considérese, igualmente, la referencia que realizan los apartados 7 y 11.a) del artículo 2 del Reglamento a "resolución judicial, por ministerio de la ley o por un acuerdo con efectos jurídicos".

${ }^{212} \mathrm{Al}$ respecto, vid. C. Esplugues, "Civil and Commercial Mediation”, cit., pp. 717-727, especialmente pp. 719-720 en relación con aquellos ordenamientos, pocos, que atribuyen, habitualmente con carácter limitado y en supuestos muy concreto, fuerza ejecutiva a los acuerdos alcanzados por las partes en el marco de una mediación. En relación con el valor de los acuerdos de mediación en el ámbito familiar en España, considérese J. Alventosa DEL Río, "Mediación familiar en España", Revista boliviana de Derecho, $n^{\circ} .8,2009$, pp. 217-218.

${ }^{213}$ Vid. M.C. Chélzz Inglés, La sustracción internacional de menores y la mediación, Valencia, Tirant lo Blanch, 2019, p. 185; M.C. Chéliz IngLÉs, "Alcance y retos", cit., pp. 269-270; C. Esplugues, "Civil and Commercial Mediation”, cit., pp. 720-727. 
la protección de su interés superior va a convertirse directamente en un notable elemento de control de su validez, requiriendo, a su vez, en algunos lugares, de la imprescindible intervención de un juez ${ }^{214}$. De hecho, en el caso de España, el artículo 19.1 LEC permite a las partes disponer del objeto del juicio y, entre otras posibilidades, "someterse a mediación ... cuando la ley lo prohíba o establezca limitaciones por razones de interés general o en beneficio de tercero". Esta referencia al tercero se entiende relevante respecto de la homologación judicial del eventual acuerdo formulado, al considerarse que la mención incluye el interés del menor ${ }^{215}$. Aceptándose, eso sí, por parte del TS que, en todo caso, aquellos acuerdos que no lesionen los derechos del menor, o los ponga en peligro, deben ser declarados vinculantes por el juez ${ }^{216}$.

\section{EI Reglamento Bruselas II ter}

73. El Reglamento (UE) 2019/1111 del Consejo, de 25 de junio de 2019, relativo a la competencia, el reconocimiento y la ejecución de resoluciones en materia matrimonial y de responsabilidad parental, y sobre la sustracción internacional de menores ${ }^{217}$-el Reglamento Bruselas II ter- con aplicación a partir del 1 de agosto de 2022, ha implicado -entre otros avances ${ }^{218}$ - un paso adicional en el fomento de la mediación, y de cualquier otro mecanismo MASC, como vía de resolución de las controversias surgidas en materia de responsabilidad parental, así como, también, de las afloradas en relación con la sustracción internacional de menores ${ }^{219}$.

74. Con ello, el Reglamento se hace eco, en última instancia, de la invitación formulada por el Consejo a la Comisión ya en 2010, en el sentido de tomar en consideración el papel positivo que la mediación puede jugar a la hora de resolver "the issues related to parental authority, rights of custody, rights of access and international child abductions" ${ }^{220}$. Este fomento, sin embargo y como seguidamente veremos, no está exento de interrogantes, especialmente en su proyección en el ámbito del reconocimiento y ejecución en los distintos Estados miembros de este tipo de acuerdos.

75. De forma coincidente con lo previsto en el artículo 55.e) del Reglamento Bruselas II bis, el artículo 79.g) del nuevo Reglamento Bruselas II ter reproduce la obligación que acompaña a las autoridades centrales requeridas de adoptar, bien directamente, o por conducto de los órganos jurisdiccionales, las autoridades competentes u otros organismos, "todas las medidas adecuadas" para, entre otros extremos, "g) facilitar la celebración de acuerdos entre los titulares de la responsabilidad parental a través de la mediación o por otros medios alternativos de resolución de litigios, y facilitar con este fin la cooperación transfronteriza" 221 . La genérica referencia a "otros medios" recogida en el artículo 55.e) del Bruselas II bis se convierte, didácticamente, en el nuevo Reglamento Bruselas II ter en una mención a "otros medios alternativos de resolución de litigios".

76. Sin embargo, junto a esta reiteración de lo previsto en el Reglamento Bruselas II bis, y en línea con la posición mantenida por distintos sectores de la doctrina en apoyo del genérico fomento del

\footnotetext{
${ }^{214}$ M.C. ChÉLIz Inglés, La sustracción internacional, cit., p. 186.

${ }^{215}$ Al respecto, vid. V. Moreno Velasco, "La ejecución del acuerdo de mediación en la relación a las materias no disponibles en las crisis matrimoniales. Una propuesta de solución”, Diario La Ley, n 7899, 2012.

${ }^{216} \operatorname{STS~n}^{\circ}$ 97/2005, de 14.2.2005 (TOL590.993), F.Dº Primero.

${ }^{217}$ DO L 178, de 2.7.2019.

${ }^{218}$ Al respecto, entre otros, B. CAMPuZAno DíAz, "El nuevo Reglamento (UE) 2019/1111: análisis de las mejoras en las relaciones con el Convenio de La Haya de 19 de octubre de 1996 sobre responsabilidad parental”, CdT, vol. 2020-1, 2020, p. 100 y ss.; L. CARPANETO, "La ricerca de una (nuova) sintesi tra interesse superiore del minore in astratto e in concreto nella riforma del Regolamento Bruxelles II-bis”, Rivista di diritto internazionale privato e processuale, vol. LIV, nº 4, 2018, p. 944 y ss.; M.C. BARUFFI, "A child-friendly area of freedom, security and justice: work in progress in international child abduction cases", Journal of private international law, vol. 14, $\mathrm{n}^{\circ} 3,2018$, p. 385 y ss.

${ }^{219}$ Al respecto, nótese, R. Espinosa Calabuig y L. Carballo PiÑeiro, “Child protection in European”, cit., p. 19.

${ }^{220}$ Council of the European Union, Conclusions of the ministerial, cit., p. 5.

${ }^{221}$ Nótese al respecto el Considerando 75 Reglamento Bruselas II ter.
} 
recurso a "esquemas" de mediación en este ámbito ${ }^{222}$, el texto de Bruselas II ter da un significativo paso adelante en favor del uso de la mediación -y de otros mecanismos de resolución alternativa de disputas- en este sector. Intentando quebrar el actual status quo, caracterizado por la escasa utilización hasta el momento de estos mecanismos, por razones distintas, en las materias cubiertas por el Reglamento ${ }^{223}$.

77. Sin alcanzar, eso sí, la apuesta favorable a una mediación obligatoria en el ámbito de la sustracción internacional de menores, favorecida por algunos en la Unión ${ }^{224}$, el texto de Bruselas II ter va mucho más allá de la tímida -pero quizás más depurada técnicamente- formulación recogida en el artículo 23.2 de la Propuesta de Reglamento del Consejo relativo a la competencia, el reconocimiento y la ejecución de resoluciones en materia matrimonial y de responsabilidad parental, y sobre la sustracción internacional de menores (refundición) presentada en 2016 por la Comisión Europea ${ }^{225}$. Y que se limitaba a señalar que "Tan pronto como sea posible durante el procedimiento, el órgano jurisdiccional examinará si las partes están dispuestas a recurrir a la mediación para encontrar, en el interés superior del niño, una solución consensuada, siempre que esto no retrase indebidamente el procedimiento."226

78. La Propuesta de Reglamento formulada por la Comisión en 2016 recogía, así, una obligación de explorar la disponibilidad de las partes, sin compelerles a ello, de recurrir exclusivamente a la mediación -y no a cualquier otro mecanismo de resolución alternativa de conflictos-, para resolver la situación creada. La solución recogida en el texto de 2019 difiere, y va más allá, de ésta.

En tal sentido, el Considerando 43 del Reglamento Bruselas II ter, retomando la filosofía de las enmiendas formuladas por el Parlamento Europeo, en 2018, al proyecto de Considerando 28 de la mencionada Propuesta de la Comisión de $2016^{227}$, explicita ahora que en todos los asuntos que afecten a menores, "y en particular en los asuntos de sustracción internacional de menores, los órganos jurisdiccionales deben contemplar la posibilidad de llegar a una solución a través de la mediación u otros medios apropiados" 228 con objeto de resolver la cuestiones que afectan al menor.

79. Significativamente, el texto propuesto por el Parlamento en 2018 sustituía la referencia incorporada por la Comisión, en el Considerando 28 de su Propuesta de 2016, a "llegar a una solución amistosa a través de la mediación u otros medios apropiados", por otra en la que la referencia quedaba exclusivamente focalizada en la mediación, obviando cualquier mención a otros medios alternativos de resolución de conflictos ${ }^{229}$.

${ }^{222}$ I. Pretelli, "Child Abduction and Return Proceedings", en European Parliament, Recasting the Brussels IIa Regulation, cit., p. 5; F.J. ForCADA MirANDA, Sustracción internacional de menores, cit., pp. 148-150.

${ }^{223}$ Vid. C. GonzÁlez Beilfuss, "La mediación en los conflictos”, cit., pp. 231-232.

${ }^{224} \mathrm{Al}$ respecto, vid. L. Heckendorn Urscheler, I. Pretelli, J. Curran et al: Enlèvements parentaux transfrontaliers dans l'Union européenne. Synthèse, Bruxelles, Parlement européen. Direction générale des politiques internes. Département thématique C: Droits des citoyens et affaires constitutionnelles. Libertés civiles, justice et affaires intérieures, 2015, p. 9. Igualmente, I. Pretelli, "Child Abduction and Return", cit., p. 11. Con carácter general, y en relación con esta propuesta, vid. G. De PaLO, L. D’Urso, M. Trevor et al: 'Rebooting' the Mediation Directive: Assessing the Limited Impact of Its Implementation and Proposing Measures to Increase the Number of Mediations in the EU, Brussels, European Parliament. Directorate General for Internal Policies. Policy Department C: Citizens' Rights and Constitutional Affairs. Legal Affairs, 2014, pp. 163-164.

${ }^{225}$ Bruselas, 30.6.2016, COM(2016) 411 final, 2016/0190 (CNS). Al respecto, E. Rodríguez PineAu, "La refundición del Reglamento Bruselas II bis: de nuevo sobre la función del Derecho internacional privado europeo”, REDI, vol. 69-1, 2017 , p. 144.

${ }^{226}$ El Considerando 28 de la Propuesta de 2016 incidía, en tal sentido, en la necesidad de que "En todos los casos que afecten a niños y, en particular, en los casos de sustracción internacional de menores, las autoridades judiciales y administrativas deben contemplar la posibilidad de llegar a una solución amistosa a través de la mediación u otros medios apropiados, con la ayuda, en su caso, de las redes y estructuras de apoyo existentes relacionadas con la mediación en las controversias de responsabilidad parental transfronteriza".

${ }^{227}$ Parlamento Europeo: Resolución legislativa del Parlamento Europeo, de 18 de enero de 2018, sobre la propuesta de Reglamento del Consejo relativo a la competencia, el reconocimiento y la ejecución de resoluciones en materia matrimonial y de responsabilidad parental, y sobre la sustracción internacional de menores (refundición), (COM(2016)0411 - C80322/2016 - 2016/0190(CNS)), DO C 458, de 19.12.2018, Enmienda 15, p. 507. Un tenor que, sin embargo, no se reproducía con similar radical en la propuesta de art. 23.2 formulada por el Parlamento (Ibid, Enmienda 45, p. 519).

${ }^{228}$ Considerando 43 del Reglamento Bruselas II bis.

${ }^{229}$ Parlamento Europeo: Resolución legislativa del Parlamento Europeo, de 18 de enero de 2018, cit., Enmienda 15. Pro- 
80. Este mandato taxativo dirigido a los tribunales de recurrir no sólo a la mediación sino a cualquier otro medio apropiado, viene desarrollado en el artículo 25 del Reglamento Bruselas II ter intitulado, específicamente, como "Formas alternativas de resolución de litigios". La rúbrica del precepto aventura una referencia al recurso a "la mediación o a otra vía alternativa de resolución de litigios" -"mediación u otros medios apropiados" en el texto del Considerando 43 del Reglamento-, conectando así -y, de hecho, superándolas- con las distintas propuestas formuladas en este sentido por algunos sectores doctrinales europeos ${ }^{230}$, y por el propio Parlamento Europeo ${ }^{231}$, que apostaban, con formulaciones diversas, por compeler a la autoridad judicial a explorar la vía de la mediación -sólo de la mediación y no de otras vías alternativas- antes de proceder a dictar una resolución judicial resolviendo la concreta situación planteada ${ }^{232}$. Admitiéndose, en todo caso, que "tales esfuerzos no deben prolongar indebidamente el procedimiento de restitución en virtud del Convenio de La Haya de 1980"233.

81. En coherencia con esta demanda de protagonismo atribuido al órgano jurisdiccional en relación con el fomento de la búsqueda de acuerdos entre las partes, dentro y fuera de un procedimiento de mediación, el artículo 25 del Reglamento Bruselas II ter exige ahora que "Lo antes posible" y "en cualquier fase del procedimiento", el órgano jurisdiccional que conozca de la eventual disputa en materia de responsabilidad parental, o del supuesto de sustracción internacional de menores, "invitará a las partes", bien de forma directa o, si procede, contando con la asistencia de las autoridades centrales "a que consideren si están dispuestas a recurrir a la mediación o a otra vía alternativa de resolución de litigios".

82. Siempre, se dice, que ello no resulte "contrario al interés superior del menor, no sea adecuado en el caso particular o conlleve un retraso indebido del procedimiento" ${ }^{234}$. Precisamente, esta idea del retraso, así como de los costes adicionales que, en concreto, el recurso a la mediación puede conllevar en

puesta de Reglamento. Considerando 28: "El recurso a la mediación puede desempeñar un papel muy importante para resolver los conflictos en todos los casos que afecten a niños y, en particular, en caso de conflictos parentales transfronterizos sobre la custodia del menor y sobre el derecho de visita del menor y en los casos de sustracción internacional de menores. Asimismo, en vista del aumento de los conflictos transfronterizos por la custodia en toda la Unión Europea, donde no se dispone de un marco internacional, como resultado de los recientes flujos migratorios, la mediación ha demostrado con frecuencia ser el único instrumento jurídico para ayudar a las familias a alcanzar una solución amistosa y rápida para los conflictos familiares. Con el fin de fomentar la mediación en esos casos, las autoridades judiciales y administrativas, con la ayuda, en su caso, de las redes y estructuras de apoyo existentes relacionadas con la mediación en las controversias de responsabilidad parental transfronteriza, deben asistir a las partes, antes o durante el proceso judicial, en la selección de mediadores adecuados y en la organización de la mediación. Se debe proporcionar a las partes una ayuda financiera para recurrir a la mediación, por lo menos en la medida en que se les haya o se les habría concedido asistencia jurídica. No obstante, tales esfuerzos no deben prolongar indebidamente el procedimiento de restitución en virtud del Convenio de La Haya de 1980 ni deben dar lugar a la participación obligatoria de las víctimas de cualquier forma de violencia, incluida la violencia doméstica, en los procedimientos de mediación" (p. 507). En similar sentido se manifestaba la propuesta de Considerando 28 bis, relativo a la formación de los mediadores (Ibid., p. 508).

${ }^{230}$ Así, por ejemplo, H. VAn Loon, “The Brussels IIa Regulation: towards a review?”, en European Parliament, Cross-Border Activities in the EU - Making Life Easier for Citizens. Workshop for the JURI Committee, Brussels, European Parliament. Directorate General for Internal Policies. Policy Department C: Citizens' Rights and Constitutional Affairs. Legal Affairs, 2015, pp. 193, 196-197 y 205; L. HeCKendorn Urscheler, I. Pretelli, J. Curran et al: Enlèvements parentaux transfrontaliers, cit., pp. 14-16 о Тн. KRUGER, "Enhancing Cross-Border Cooperation”, cit., p. 43 quizás, de todas, la que propone un texto más similar al finalmente incorporado en el Reglamento. Todos ellos, significativamente, refieren exclusivamente a la mediación y no a otros medios MASC.

${ }^{231}$ Parlamento Europeo: Resolución legislativa del Parlamento Europeo, de 18 de enero de 2018, cit., Enmienda 15. Propuesta de Reglamento. Considerando 28 (p. 507), y Enmienda 45. Propuesta de Reglamento. Artículo 23 — apartado 2 (p. 519).

${ }^{232}$ La mención a mediación y otras vías complementarias se consolidará en la propuesta remitida al Consejo (Article 23 bis. Modes alternatifs de règlement des litiges), Conseil de L'Union euRopéEnNe: Proposition de règlement du Conseil relatif à la compétence, la reconnaissance et l'exécution des décisions en matière matrimoniale et en matière de responsabilité parentale, ainsi qu'à l'enlèvement international d'enfants (refonte) - Orientation générale, Bruxelles, le 30 novembre 2018 (OR. en), Dossier interinstitutionnel: 2016/0190(CNS), 14784/18, JUSTCIV 292, p. 41.

${ }^{233}$ Considerando 28 Propuesta de Reglamento de 2016.

${ }^{234}$ En tal sentido, B. MussEva: "The recast of the Brussels IIa Regulation: the sweet and sour fruits of unanimity", ERA Forum, $\mathrm{n}^{\mathrm{o}}$ 21, 2020, pp. 136-137. Lo que apoyaría, por ejemplo, la formación -y concienciación- del mediador en relación con esta cuestión. Al respecto, R. Espinosa Calabuig y L. Carballo Piñeiro, "Child protection in European family law", en T. Pfeiffer, Q.C. Lobach y T. RApP (Eds.), Facilitating Cross-border family life - Towards a common European Understanding, Heidelberg, Heidelberg University Publishing, 2021, p. 21. 
los procedimientos de restitución, es resaltada, desde antiguo, por la doctrina como una de las trabas que inciden sobre su utilización en este sector ${ }^{235}$. Asumiéndose, igualmente, las dificultades de que algunas de las ventajas que la mediación, puede ofrecer se manifiesten efectivamente en este ámbito temático: “(dialogue, rapidité, efficacité) semble toutefois assez utopique, étant donné que ce type de litige s'avère extrêmement conflictuel et compliqué" ${ }^{236}$.

83. El cambio de filosofía y de enfoque es doblemente relevante al favorecer el legislador europeo, en primer lugar, la sustitución de "la lógica de la confrontación por la del acuerdo" 237 y hacerlo, además, de forma amplia, apostando por la búsqueda del consenso dentro o fuera de una mediación. Lo que en sí mismo constituye una opción relevante dado que, dejando de lado las diferencias que puedan existir en cuanto a la naturaleza y desarrollo en la práctica de los distintos MASC potencialmente utilizados, sólo la mediación cuenta con un soporte normativo europeo.

Una alteración que encuentra su reflejo directo en el dato de que el potencial logro de acuerdos en esta materia ya no queda exclusivamente referido a las partes, sino que los tribunales se ven igualmente atribuido un papel activo en esta búsqueda, al quedar ahora compelidos a invitar a las partes a explorar un eventual consenso. En esta tarea, añade el Considerando 43 del texto reglamentario, el juez contará con la ayuda, "cuando corresponda, de las redes y estructuras de apoyo existentes para la mediación en las controversias transfronterizas en materia de responsabilidad parental" ${ }^{238}$. Una exigencia de involucración que está en línea con el mandato del punto 15 de la Carta Magna de los jueces europeos, de 17 de noviembre de $2010^{239}$, que compele al juez a actuar para asegurar la consecución de una solución rápida, eficaz y a un coste razonable de los litigios. Y que, en tal sentido, "debe contribuir a la promoción de métodos alternativos de resolución de conflictos".

84. Sin embargo, como el mencionado Considerando 43 del Reglamento Bruselas II ter admite, esta exigencia que acompaña al juez de invitar a las partes a contemplar la posibilidad de buscar y, en su caso alcanzar, un acuerdo en relación con la disputa planteadas no es absoluta, y se avanzan distintas excepciones de índole diversa. Se habla así de ciertas materias en las que se considera que la referencia -específicamente- "a la mediación" no siempre resulta apropiada; "en especial en los casos de violencia sobre la mujer" ${ }^{240}$. Y en todo caso, se reitera, en relación con el concreto supuesto de la sustracción internacional de menores, que el recurso a la mediación no debe suponer una prolongación indebida del

\footnotetext{
${ }^{235} \mathrm{Al}$ respecto, A. Borrás Rodríguez, "Bruselas II, Bruselas II bis, Bruselas II ter...”, REEI, no 38, diciembre 2019, p. 4, y C. GonzÁlez BeIlfuss, "La sustracción de menores en el nuevo Reglamento 1019/1111”, en S. Álvarez GonzÁlez, R. Arenas García, P.A. De Miguel Asensio et al (Eds.), Relaciones transfronterizas, globalización y Derecho. Homenaje al Profesor Doctor José Carlos Fernández Rozas, Madrid, Civitas Thomson Reuters, 2020, p. 396; M. Brosch y C.M. MariotinNi, EUFAMS II. Facilitating, cit., p. 20. Una mención a los costes que ya será apuntada en 2021 por la Conferencia de La Haya de DIPr en su Guía de Buenas Prácticas (Hague Conference on Private International Law, Guía de Buenas Prácticas, cit., p. 53 y ss.). Precisamente con objeto de limitar este impacto en los costes, el Parlamento Europeo, en su Resolución sobre la propuesta de refundición del Reglamento II bis presentada por la Comisión Europea en 2016 afirmaba en su enmienda 15 (por la que se modificaba el Considerando 28 de dicha propuesta), la obligación de proporcionar a las partes una ayuda financiera para recurrir a la mediación, "por lo menos en la medida en que se les haya o se les habría concedido asistencia jurídica" (PARLAMENTO Europeo: Resolución legislativa del Parlamento Europeo, de 18 de enero de 2018, cit., p. 507). Una propuesta reflejada en el texto modificado del art. 38.1.b) de la Propuesta (ParLamento Europeo: Resolución legislativa del Parlamento Europeo, de 18 de enero de 2018, cit., Enmienda 52, p. 521). De hecho, la propia Conferencia de La Haya de Derecho Internacional Privado es consciente de ello, como se observa en el hecho de congratularse del logro de una disminución en las demoras en los procedimientos en virtud del Convenio, también, en el plano de la mediación (al respecto, Conferencia de La HaYA DE DERECHO Internacional Privado, Comisión Especial sobre el funcionamiento práctico de los Convenios de La Haya de 1980 y 1996 (10 - 17 de octubre de 2017), cit., p. 2, no 14.

${ }^{236}$ B. JURIK, "Le « nouveau » Règlement Bruxelles II ter: le changement, ce n'est pas pour maintenant!", JADE Journal d'Actualitè des Droit Européens, n'. 20, 2019, 30.10.2019.

${ }^{237}$ C. GonzÁlez Beilfuss, "La sustracción de menores”, cit., p. 397.

${ }^{238}$ Considerando 43 del Reglamento Bruselas II bis.

${ }^{239}$ Consejo Consultivo de los Jueces Europeos (CCJE), Carta Magna de los Jueces (Principios Fundamentales) (disponible en: https://www.poderjudicial.es/stfls/cgpj/OTROS\%20DOCUMENTOS/FICHERO/CARTA\%20MAGNA\%20CCJE\%20 ESP_1.0.0.pdf).

${ }^{240}$ Considerando 43 del Reglamento Bruselas II bis.
} 
procedimiento de restitución en virtud del Convenio de La Haya de 1980 sobre los aspectos civiles de la sustracción internacional de menores ${ }^{241}$.

85. El artículo 25 del Reglamento Bruselas II ter adquiere, de esta suerte, una especial relevancia, tanto por su contenido mismo, como por los cambios que incorpora respecto del texto de 2003, reflejando la clara voluntad del legislador europeo de fomentar el logro de acuerdos en este ámbito: bien a través de la mediación, o recurriendo a otros mecanismos de resolución alternativa de disputas. Sin embargo, más allá de esta clara voluntad, el precepto presenta distintas limitaciones y problemas de naturaleza diversa, que pueden afectar, en última instancia, a la virtualidad de la solución articulada o, al menos a su plácida práctica.

\section{A) El contenido del acuerdo en materia de responsabilidad parental}

86. En primer lugar, y desde el punto de vista del contenido del acuerdo alcanzado en relación con la responsabilidad parental y la sustracción internacional de menores ${ }^{242}$, los interrogantes se focalizan en aquellos acuerdos que puedan ir más allá del puro contenido relacional -los que presentan como finalidad exclusiva la mejora de las relaciones entre las partes, y que por su propia naturaleza no son coercibles-, recogiendo contenidos dotados de vocación jurídica, que son susceptibles de ser judicializados y ejecutados en el futuro ${ }^{243}$. En relación con éstos últimos cabe la posibilidad de que se supere al perímetro estricto de las materias incardinables en el concepto de "responsabilidad parental", pudiendo cubrir otras cuestiones, o ámbitos, vinculadas, por ejemplo, con el régimen económico matrimonial o los alimentos ${ }^{244}$. Sectores, ambos, regulados por otros instrumentos europeos distintos del Reglamento Bruselas II ter -en concreto, y respectivamente, los Reglamentos (UE) 2016/1103 y 1104, sobre régimen económico matrimonial y sobre efectos patrimoniales de las uniones registradas, y el Reglamento 4/2009-.

87. Además de los interrogantes -macro- que ello genera en relación con el sistema en su globalidad, con su diseño y funcionamiento. Puede, igualmente, desde una perspectiva micro, suscitar la cuestión añadida, y compleja, de concretar tanto la competencia para su homologación como las vías para asegurar su eficacia.

Esto es, desde un punto sistemático, lo anterior supone asumir que en un espacio jurídicamente integrado como es el europeo, diversas cuestiones abordadas en un mismo acuerdo van a ser susceptibles de verse reguladas por normas distintas dotadas, en ocasiones, de objetivos desiguales, y que pueden dar lugar a procedimientos diferenciados y grados de eficacia variados. Una problemática ésta que, ciertamente, desde la perspectiva estricta del funcionamiento del Reglamento Bruselas II ter ve limitada su trascendencia al atender a la definición de "acuerdo" recogido en su artículo 2.2.3), y que refiere a un documento que ha sido firmado por las partes en materias que "entran en el ámbito de aplicación del Reglamento"245. Pero que, en la práctica, supone consolidar la fragmentación del modelo europeo de DIPr, y de la respuesta aportada por éste, de la que la eficacia extraterritorial de los acuerdos alcanzados por las partes en el ámbito del Derecho de Familia constituye un buen ejemplo.

\footnotetext{
${ }^{241}$ BOE de 24.8.1987.

${ }^{242}$ De acuerdo con el art. 2.2.7) del Reglamento, se entiende por "responsabilidad parental": "los derechos y obligaciones conferidos a una persona física o jurídica en virtud de una resolución, por ministerio de la ley o por un acuerdo con efectos jurídicos, en relación con la persona o los bienes de un menor, incluidos, en particular, los derechos de custodia y visita".

${ }^{243}$ Sobre la distinción entre ambas categorías de contenidos, vid. S. Algaba Ros, "El acuerdo de mediación familiar: su singularidad", InDret, 2017-4, pp. 26-28.

${ }^{244} \mathrm{Al}$ respecto, J.M. VARA GonzÁlez, “Aspectos notariales de la Ley de Mediación. Referencia a la mediación familiar”, Revista Jurídica del Notariado, no 82, abril-junio, 2012, p. 479 y ss.

245 "y que ha sido registrado por una autoridad pública comunicada a la Comisión con este fin por un Estado miembro de conformidad con el artículo 103", algo que, a fecha de elaboración de este articulo, todavía no se había producido.
} 


\section{B) La posibilidad de prórroga del foro con respecto a la homologación del acuerdo alcanzado}

88. Adicionalmente, la solución recogida en el artículo 25 del Reglamento II ter con referencia a los acuerdos alcanzados en relación con la responsabilidad parental y a la sustracción internacional de menores - tanto en el marco de un procedimiento de mediación como a través de otra vía alternativa de resolución de conflictos-, tiene un impacto en el funcionamiento del modelo de competencia judicial internacional articulado en el texto reglamentario, abriendo la puerta a la posible prórroga de la competencia.

89. En este sentido, y en relación específicamente con la sustracción internacional de menores, el Considerando 43 del Reglamento, en línea con su Considerando 22, explicita que en aquellas ocasiones en que, en el curso de un procedimiento de restitución al amparo del Convenio de La Haya de 1980, los progenitores lleguen a un acuerdo en el Estado miembro donde ha sido trasladado el menor, no solamente sobre la restitución o no restitución del menor, sino también sobre otras cuestiones de responsabilidad parental, se debe permitir a las partes, en ciertas circunstancias, "convenir en que el órgano jurisdiccional al que se haya recurrido con arreglo al Convenio de La Haya de 1980 sea competente para dar efecto jurídico vinculante a su acuerdo" si éste, insistimos, se ha alcanzado durante dicho procedimiento de restitución ${ }^{246}$. Un objetivo que se logra ya sea, a través de su incorporación a una resolución que lo aprueba, o de otra forma prevista por la legislación y el procedimiento nacionales ${ }^{247}$.

90. Lo anterior conlleva, adicionalmente, tal como reconocen los apuntados Considerandos 22 y 43 del Reglamento, que los Estados miembros que hayan concentrado la competencia material, en consonancia con el propio Reglamento -y en tal sentido resulta muy interesante el tenor de su Considerando 41- deben considerar la posibilidad de permitir que el concreto órgano jurisdiccional al que se ha sometido la demanda de restitución con arreglo al Convenio de La Haya de 1980 ejerza, también, la competencia -acordada o aceptada por las partes en virtud del Reglamento- en materia de responsabilidad parental. Siempre, conviene recordar, que tal acuerdo entre las partes se haya alcanzado durante los procedimientos de restitución ${ }^{248}$.

91. Esta posibilidad de prórroga de la competencia se encuentra en línea con el mandato de los artículos 9 y 10 del Reglamento Bruselas II ter ${ }^{249}$, y es valorada positivamente por la doctrina que, con independencia de la efectividad de la admonición incorporada en el precepto, entiende su carácter pedagógico y asume, tanto que el órgano de origen, previsiblemente, no estará familiarizado con la controversia, como el hecho de que, además, puede que deje pronto de ser competente si, efectivamente, el acuerdo alcanzado por las partes implica la permanencia del menor en el Estado al que ha sido traslado, o donde se encuentra retenido ${ }^{250}$. Amén de, también, todos los problemas que pueden derivarse en la práctica de la no previsión de esta prórroga ${ }^{251}$.

\section{C) La eficacia del acuerdo alcanzado en la UE y su circulación en el seno de la UE}

92. Un tercer nivel de problematismo planteado por la solución recogida en el Reglamento Bruselas II ter es recurrente, y reitera la situación existente en la Unión en relación con la eficacia de este

\footnotetext{
${ }^{246}$ Considerando 43 Reglamento Bruselas II ter. Nótese, igualmente, el Considerando 22 del Reglamento y M.C. CHÉLIZ INGLÉs, La sustracción internacional, cit., p. 187.

${ }^{247}$ Considerando 43 Reglamento Bruselas II ter. Nótese, igualmente, el Considerando 22 del Reglamento.

${ }^{248}$ Este tipo de acuerdos, añade el Considerando 22 del Reglamento, "debe incluir tanto los acuerdos de restitución como los de no restitución del menor. Si se acuerda la no restitución, el menor deber permanecer en el Estado miembro del nuevo lugar de residencia habitual y la competencia para cualquier futuro procedimiento de custodia que se inicie alli debe determinarse sobre la base del nuevo lugar de residencia habitual del menor".

${ }^{249}$ Una posibilidad que estaría ya latente en el Reglamento Bruselas II bis, al respecto, C. GonzÁlez BeILfuss, "La sustracción de menores", cit., p. 389.

${ }^{250}$ C. GonzÁlez BeILfuss, "La sustracción de menores”, cit., pp. 389-390.

${ }^{251} \mathrm{Al}$ respecto, vid. M.C. CHÉLIz INGLÉs, La sustracción internacional, cit., p. 186
} 
tipo de acuerdos, y con su posterior circulación en el territorio de la UE. Adquiriendo, además, una complejidad adicional a la vista del tenor del artículo 65 del Reglamento, en el que se consolida una nueva categoría de títulos susceptibles de ser reconocidos y ejecutados en la UE, y que va más allá de la figura de la mediación: la de "acuerdos entre las partes que tengan fuerza ejecutiva en el Estado miembro de origen", ya prevista expresamente en el artículo 46 del Reglamento Bruselas II bis, pero que ahora se ve notablemente desarrollada en el nuevo texto de 2019.

\section{a) Resoluciones judiciales, documentos públicos y acuerdos}

93. La doctrina y los operadores jurídicos son muy conscientes de que el éxito, específicamente, de la mediación -y del resto de medios MASC- en cualquier de los sectores en que sea usada y, también, lógicamente, en el ámbito familiar, estriba en facilitar la eficacia del acuerdo alcanzado ${ }^{252}$. En el supuesto concreto del Reglamento Bruselas II ter, y en relación específicamente con los acuerdos formulados dentro -o fuera- de una mediación transfronteriza en las materias cubiertas por éste, se asume esta premisa -y objetivo- de asegurar su circulación en Europa, apuntándose gráficamente por la doctrina europea que, "évidemment il ne sert à rien qu'une mère" - o un padre, añadiríamos nosotros- "signe un document en sachant qu'il n'a aucune force juridique"253.

94. Ya se ha avanzado ${ }^{254}$ cómo de forma muy mayoritaria se acepta en Europa que el compromiso alcanzado por las partes en el marco de una mediación cuenta con una naturaleza privada -puramente contractual-, resultando por lo tanto necesario recurrir a los tribunales para hacer cumplir lo acordado en caso de incumplimiento por alguna de las $\operatorname{partes}^{255}$. Esta es una realidad de la que ya se hizo eco en su momento el Libro Verde sobre las modalidades alternativas de solución de conflictos en el ámbito del derecho civil y mercantil preparado por la Comisión con fecha 19 de abril de $2002^{256}$. Y que perdura en nuestros días reputándose, igualmente, de aquellos acuerdos concluidos fuera de la mediación y a los que, al carecerse de normativa armonizada, se aplicará en cada país de la Unión su propio régimen jurídico ${ }^{257}$. Recuérdense en este sentido, en el caso de España, por ejemplo, las limitaciones recogidas en relación con el contrato de transacción en el artículo $1814 \mathrm{Cc}^{258}$, respecto del mandato genérico del artículo $1810^{259}$ del mismo cuerpo legal.

95. En concreto, el acuerdo concluido en el marco de un procedimiento de mediación requiere, por lo tanto, de su homologación por el órgano jurisdiccional, o por una autoridad pública, del Estado en el que se ha alcanzado, para contar con fuerza ejecutiva en éste. La situación existente en España es paradigmática en este sentido, al apuntar el artículo 23.3 de la Ley española de mediación cómo una

${ }^{252}$ Vid., C. Esplugues, “General Report”, cit., p. 68.

${ }^{253}$ S. Corneloup y T. Kruger, "Le Règlement 2019/1111, Bruxelles II: la protection des enfants gagne du ter(rain)”, Rev. crit. DIP, 2020-2, p. 224.

${ }^{254}$ Vid. $n^{\circ} 57$ supra.

${ }^{255}$ Respecto de España, vid. J.L. Iglesias Buhigues, C. Esplugues Mota, G. Palao Moreno et al, "Spain”, en C. Esplugues, J.L. Iglesias y G. Palao (Eds.), Civil and Commercial Mediation in Europe. National Mediation Rules and Procedures. Vol. I, Cambridge, intersentia, 2013, pp. 478-479; A. García Herrera, "Reestructuración de la familia cit., p. 11; S. Algaba Ros, "El acuerdo de mediación", cit., pp. 31-32.

256 "Según los Estados, las ADR pueden desembocar frecuentemente en una simple transacción de carácter contractual pero también en otras fórmulas, como un acta de conciliación o de acuerdo de mediación. El denominador común de todas estas fórmulas es que en realidad constituyen "transacciones", sea cual fuere la apelación que se les da", Bruselas, 19.4.2002, $\operatorname{COM}(2002) 196$ final, p. 34, no 85.

${ }^{257}$ Sobre la distinción entre los acuerdos concluidos en el seno de un procedimiento de mediación y aquellos que lo son fuera de éste, vid. C. Esplugues Mota, "La Convención de Singapur de 2018 sobre mediación y la creación de un título deslocalizado dotado de fuerza ejecutiva: una apuesta novedosa, y un mal relato", REDI, vol. 72, 2020, pp. 63-66.

${ }^{258}$ Art. 1814 Cc: "No se puede transigir sobre el estado civil de las personas, ni sobre las cuestiones matrimoniales, ni sobre alimentos futuros".

${ }^{259}$ Art. 1810 Cc.: "Para transigir sobre los bienes y derechos de los hijos bajo la patria potestad se aplicarán las mismas reglas que para enajenarlos". 
de las obligaciones del mediador es, precisamente, la de informar "a las partes del carácter vinculante del acuerdo alcanzado y de que pueden instar su elevación a escritura pública al objeto de configurar su acuerdo como un título ejecutivo". Máxime en este tipo de pactos en materia de responsabilidad parental y sustracción de menores en los que los progenitores convienen sobre aspectos que afectan a uno o varios de estos últimos ${ }^{260}$.

96. Esta homologación se traduce, habitualmente -ya lo indica, recordemos la propia Directiva de 2008 en su artículo 6 -, bien en la incorporación de lo convenido en una resolución aprobatoria, en el supuesto de ratificación de aquel por una autoridad judicial "después de haber examinado su fondo de conformidad con el Derecho y los procedimientos nacionales" ${ }^{261}$. O, se realiza a "través de otra forma prevista por la legislación y el procedimiento nacionales"262; por ejemplo, en el caso de España, mediante su elevación a escritura pública por un notario, tal como requieren los artículos 25 y 27.2 de la Ley $5 / 2012$, de 6 de julio, de mediación en asuntos civiles y mercantiles ${ }^{263}$-en línea con la filosofía y el mandato del artículo 517.2.2 $2^{\circ}$ LEC $^{264}$. Preceptos, que entre otros extremos, reintroducen el control de legalidad por parte del notario, suprimido en su día de los artículos 145, 197 quáter y 198 del Reglamento Notarial por la jurisprudencia del $\mathrm{TS}^{265}$.

97. Como ya hemos señalado, el propio Parlamento Europeo, en su Resolución de 12 de septiembre de 2017, en relación con la aplicación de la Directiva sobre mediación de 2008, no ha dudado en considerar que esta exigencia de homologación origina costes adicionales, es lenta para las partes del acuerdo y, puede "afectar negativamente a la circulación de acuerdos de mediación extranjeros, especialmente en el caso de litigios menores"266; aunque, también podría añadirse, que no deja de constituir una garantía para las propias partes y, especialmente, para el menor. Conduciendo, en suma, a la Cámara a instar la adopción de medidas tendentes a "garantizar el carácter ejecutorio de los acuerdos de mediación de manera rápida y asequible, dentro del pleno respeto de los derechos fundamentales, así como de la legislación nacional y de la Unión" 267.

98. En su proyección al ámbito de la circulación en el seno de la Unión de los acuerdos concluidos por las partes en el marco de un procedimiento de mediación -aquel en el que aquellas "intentan voluntariamente alcanzar por sí mismas un acuerdo sobre la resolución de su litigio con la ayuda de un mediador"268 - o fuera de éste, tal homologación por la autoridad nacional supone dotar al acuerdo de fuerza ejecutiva que, lógicamente, se desplegará exclusivamente en el territorio del Estado de dicha autoridad.

99. Así, para que el acuerdo produzca efectos más allá del foro será necesario su reconocimiento y, en su caso, ejecución en el Estado en que se pretenda su eficacia. En este sentido, las reglas recogidas en el nuevo texto de 2019 intentan favorecer y facilitar esta eficacia extraterritorial, aunque de ellas se desprende una cierta sensación de excesiva complejidad, con todo lo que ello puede suponer en un ámbito que requiere, precisamente, de disposiciones claras y dúctiles. Así, se dice, las normas "sont d'une lecture difficile et auraient manifestement supporté un effort de pédagogie et de simplification"269.

\footnotetext{
${ }^{260}$ Abogando por una flexibilización de esta posición, y con una amplia referencia jurisprudencial, vid. S. AlgABA Ros, "El acuerdo de mediación", cit., pp. 29-31.

${ }^{261}$ Considerando 14 Reglamento Bruselas II ter.

${ }^{262}$ Considerando 43 Reglamento Bruselas II ter.

${ }^{263}$ BOE de 7.7.2012. Vid. M.C. CHÉLIz InGLÉs, La sustracción internacional, cit., pp. 337-348.

${ }^{264}$ Considérese, igualmente, el art. 550.1.1 ${ }^{\circ}$ LEC, que al abordar los documentos que han de acompañar a la demanda ejecutiva exige que cuando el título sea un acuerdo de mediación elevado a escritura pública, deberá acompañarse, "además, copia de las actas de la sesión constitutiva y final del procedimiento".

265 J.M. VARA GonZÁlez, “Aspectos notariales”, cit., pp. 454 y 462.

${ }^{266}$ Parlamento Europeo, Resolución del Parlamento Europeo, de 12 de septiembre de 2017, cit., Conclusión principal (10).

${ }^{267}$ Parlamento Europeo, Resolución del Parlamento Europeo, de 12 de septiembre de 2017, cit., Conclusión principal (10).

${ }^{268}$ Art. 3.a) Directiva 2008/52/CE.

${ }^{269}$ E. Gallant, "Le nouveau Règlement 'Bruxelles II ter'”, AJ Famille, 2019, p. 401 y ss. (reproducido en: http://publications.ut-capitole.fr/42755/1/Le\%20nouveau\%20R\%C3\%A8glement\%20Bruxelles\%20II\%20ter.pdf, p. 6).
} 
100. El Reglamento Bruselas II ter asume en su artículo 64 y ss. la existencia de una pluralidad de títulos vinculados al eventual pacto alcanzado por las partes en relación con la responsabilidad parental, o el traslado ilícito de menores, susceptibles de circular libremente en el seno de la Unión: en primer lugar, la resolución judicial que homologa el eventual acuerdo concluido por las partes en el marco de una mediación o fuera de ella. En segundo, la escritura pública que lo incorpora. Y, en tercer lugar, el acuerdo mismo celebrado por las partes dentro o fuera de una mediación, que sean ejecutivos en un Estado miembro, y a los que el Reglamento Bruselas II bis asimilaba a "resoluciones judiciales" 270 .

101. Respecto de estas tres categorías, el Reglamento Bruselas II ter afirma de forma genérica -y también taxativa- que, tanto la resolución, como el documento público que homologuen el acuerdo alcanzado por las partes circularán en el territorio de la Unión con base en el principio de confianza mutua. Lo que se traduce, tal como señala el Considerando 55 del Reglamento, en la limitación de los motivos de denegación del reconocimiento "al mínimo necesario, habida cuenta del objetivo subyacente del presente Reglamento que es facilitar el reconocimiento y la ejecución y proteger de forma eficaz el interés superior del menor".

1) Ello supone, en el caso de una resolución judicial homologando el acuerdo, que ésta "debe ser reconocid(a) o ejecutad(a) como una «resolución»" 271 , atendiendo al modelo de reconocimiento y ejecución diseñado para ellas en el Reglamento ${ }^{272}$.

2) Por su parte, en segundo lugar, en el supuesto de tratarse de un documento público que incorpore el acuerdo alcanzado por las partes -dotado de "efecto jurídico vinculante en el Estado miembro de origen tras la intervención formal de una autoridad pública o de otra autoridad comunicada por un Estado miembro a la Comisión para tal fin"273 - éste debe hacerse efectivo en los demás Estados miembros con arreglo a las disposiciones específicas del Reglamento sobre documentos públicos recogidas en su artículo 64 y ss.

102. Sin embargo, recordemos, junto a estas dos categorías "clásicas" en la geografía jurídica europea -resolución judicial o documento público que homologan el pacto concluido por las partes-, el Reglamento Bruselas II ter refiere, igualmente, a una tercera categoría -no tan, "novedosa"274_, apuntada ya en el texto de 2003, y que ahora se consolida y regula de forma detallada. Se trata, sin más, de ciertos "acuerdos" concluidos por las partes en el seno de una "mediación" u "otra vía alternativa de resolución de litigios", tal como señala el artículo 25 del texto de 2019.

103. En relación con ellos, el legislador europeo distingue entre aquellos acuerdos que cuentan con una naturaleza estrictamente privada, y aquellos otros que, sin haber sido homologados por una autoridad judicial o extrajudicial, se encuentran registrados, otorgando un tratamiento notablemente diverso a unos y otros.

1) Así, con respecto a los primeros, los acuerdos alcanzados por las partes mediante la intervención de un mediador, o recurriendo a cualquier otro mecanismo MASC, y que por no haber sido homologado por una autoridad pública o un juez cuentan con una naturaleza estrictamente privada, el Considerando 14 del Reglamento Bruselas II ter deja claro que el objetivo del texto de 2019 no es "autorizar la libre circulación de acuerdos meramente privados". Antes, al contrario, el propio texto reglamentario explicita que tal circulación "no debe" au-

\footnotetext{
${ }^{270}$ Considerando 22 y art. 46 Reglamento Bruselas II bis.

${ }^{271}$ Considerando 14 Reglamento Bruselas II ter.

${ }^{272}$ Lo que suscita, con carácter previo, la cuestión de la competencia para homologar el acuerdo, al respecto, M.C. CHÉLIZ INGLÉs, "La ejecución de los acuerdos resultantes de mediación familiar: el conflicto de los "package agreements" en materia de sustracción internacional de menores”, en C. AzcÁrraga Monzonis y P. Quinzá Redondo (Eds.), Tratado de mediación, cit., p. 44.

${ }^{273}$ Considerando 14 Reglamento Bruselas II ter.

${ }^{274}$ En palabras de S. Corneloup y T. Kruger, “Le Règlement 2019/1111”, cit., p. 238.
} 
torizarse, al tratarse de acuerdos dotados de una naturaleza puramente contractual, y carentes de fuerza ejecutiva, añadiríamos nosotros.

2) Junto a ello, y en claro contraste con lo anterior, el objetivo del Reglamento, tal como precisa su Considerando 2, sí que es facilitar "la circulación en la Unión de las resoluciones, los documentos públicos y determinados acuerdos", procediéndose en tal sentido a "establecer disposiciones relativas a su reconocimiento y ejecución en otros Estados miembros".

En otras palabras, y así lo indica el Considerando 14 del Reglamento, a diferencia de lo que ocurre con los acuerdos dotados de naturaleza estrictamente privada, sí debe facilitarse la circulación en la UE de aquellos compromisos concluidos por las partes:

1) que hayan sido alcanzados en el marco de una mediación, $u$ otro mecanismo ADR en el territorio de los distintos Estados de la Unión.

2) que, no siendo ni una resolución judicial ni un documento público,

3) "tengan efecto jurídico vinculante y tengan fuerza ejecutiva en el Estado miembro de origen" $275 \mathrm{y}$

4) "hayan sido registrados por una autoridad pública competente para hacerlo"276,

5) en un Estado miembro que "ejerza su competencia con arreglo al capítulo II" del Reglamento ${ }^{277}$.

Entre tales autoridades públicas, añade el Considerando 14 del texto reglamentario "pueden figurar los notarios que registren acuerdos, aun cuando estén ejerciendo una profesión liberal.". La cuestión, lógicamente, es determinar a qué tipo de acuerdos nos estamos refiriendo. Asumiendo, adicionalmente, que el Reglamento disocia en cuanto a su tratamiento a los acuerdos sobre crisis matrimoniales, de aquellos relativos a la responsabilidad parental.

104. Tal como afirma el artículo 2.2.3) del Reglamento Bruselas II ter al proceder a fijar el significado del término "acuerdo" a efectos de las normas sobre reconocimiento y ejecución recogidas en su Capítulo IV -"Reconocimiento y ejecución"-, bajo esta denominación estamos hablando de "un documento que no es un documento público ${ }^{278}$, que ha sido firmado por las partes en materias que entran en el ámbito de aplicación del presente Reglamento y que ha sido registrado por una autoridad pública comunicada a la Comisión con este fin por un Estado miembro de conformidad con el artículo 103" del texto reglamentario, "d'un État dont les juridictions sont competentes". Lo que supone que la autoridad pública deberá, aunque sea de una forma indirecta, "respecter les règles de compétence judiciaire prévues par le Règlement"279.

105. Este categoría de acuerdos, calificado por algunos como acuerdos "ovni" 280 , pueden haberse alcanzado, dentro o fuera de una mediación, y referir a la separación legal y divorcio, o a la responsabilidad parental y/o sustracción internacional de menores. En relación con los primeros -los acuerdos en materia de separación legal y divorcio- si cuentan con efecto jurídico vinculante en el Estado miembro de origen, "se reconocerán en otros Estados miembros sin que se requiera ningún procedimiento especial", atendiendo a lo previsto en las reglas sobre reconocimiento recogidas en la sección 1 del Capítulo IV del Reglamento ${ }^{281}$.

${ }^{275}$ Art. 65.2 Reglamento Bruselas II ter.

${ }^{276}$ Considerando 14 Reglamento Bruselas II ter.

${ }^{277}$ Art. 64 Reglamento Bruselas II ter.

${ }^{278}$ Definido éste en el art. 2.2.2) del Reglamento, en el sentido de documento formalizado o registrado oficialmente como documento público en cualquier Estado miembro en materias comprendidas en el ámbito de aplicación del Reglamento y cuya autenticidad queda referida a la firma y contenido del instrumento y, además, ha sido establecido por una autoridad pública u otra autoridad habilitada a tal fin, de acuerdo con el art. 103 del Reglamento.

${ }^{279}$ E. Gallant, "Le nouveau Règlement", cit., p. 3.

${ }^{280}$ J.-S. QuÉGUINER: "Le divorce sans juge en droit international privé”, Droit de la Famille, septembre, no. 9, 2018 , p. 1.

${ }^{281}$ Art. 65.1 Reglamento Bruselas II ter. 
106. Por su parte, respecto de los acuerdos en materia de responsabilidad parental y/o sobre sustracción de menores, si tienen efecto jurídico vinculante y fuerza ejecutiva en el Estado miembro de origen "se reconocerán y ejecutarán en otros Estados miembros sin que se requiera ninguna declaración de fuerza ejecutiva. Se aplicarán en consecuencia las secciones 1 y 3" ${ }^{82}$ del Capítulo IV del Reglamento, salvo disposición en contrario en la sección 4, en la que, específicamente se aborda la eficacia extraterritorial de los "Documentos públicos y acuerdos" que, recordemos, comparten el mismo régimen jurídico.

107. La realidad jurídica europea pone de manifiesto la existencia, aislada, de ejemplos de esta categoría de acuerdos en el ámbito, específicamente, de las crisis matrimoniales. El artículo 229-1 Cc francés ${ }^{283}$ constituiría el ejemplo paradigmático, no exento de críticas $^{284}$, de ello ${ }^{285}$, hablándose por algunos, incluso, de una solución diseñada en el Reglamento para favorecer su circulación ${ }^{286}$. Sin embargo, no es un supuesto habitual y su aceptación en relación con la responsabilidad parental es aún limitada y compleja. No olvidemos, en tal sentido, cómo, por ejemplo, en España, el artículo 87 Cc reconoce a los cónyuges su derecho a "acordar su divorcio de mutuo acuerdo mediante la formulación de un convenio regulador ante el Secretario judicial o en escritura pública ante Notario, en la forma y con el contenido regulado en el artículo 82, debiendo concurrir los mismos requisitos y circunstancias exigidas en él." Y que, precisamente el apartado 2 de este artículo 82 excluye esta posibilidad "cuando existan hijos menores no emancipados o con la capacidad modificada judicialmente que dependan de sus progenitores". Ello afecta directamente a su circulación fuera de las fronteras del país en que se ha alcanzado el acuerdo ${ }^{287}$.

108. Además, lejos de preverse por el legislador nacional el tratamiento de la problemática de este tipo de acuerdos alcanzados por las partes en relación con la responsabilidad parental o la sustracción internacional de menores -y de su eficacia interna- de forma individualizada y autónoma, tiende a abordarse habitualmente en el marco de otras realidades independientes como, por ejemplo, puedan ser las crisis matrimoniales; a modo de ejemplo singular, el artículo 14 del DL n. ${ }^{\circ} 272 / 2001$, de 13 de Octubre Processos da competência do M. ${ }^{\circ}$. $^{\circ}$ e das C. Registo Civil portugués ${ }^{288}$, refiere exactamente a los acuerdos sobre responsabilidad parental concluidos por las partes en el marco de un divorcio por mutuo consentimiento, que son autorizados e inscritos por el encargado del Registro Civil ${ }^{289}$-. O, también, los alimentos, como ocurre con el artículo 50.3 de la Marriage Act nº 234/1929 finlandesa-290.

\footnotetext{
${ }^{282}$ Art. 65.2 Reglamento Bruselas II ter.

${ }^{283}$ Art. 229-1 Cc: "Lorsque les époux s'entendent sur la rupture du mariage et ses effets, ils constatent, assistés chacun par un avocat, leur accord dans une convention prenant la forme d'un acte sous signature privée contresigné par leurs avocats et établi dans les conditions prévues à l'article 1374.

Cette convention est déposée au rang des minutes d'un notaire, qui contrôle le respect des exigences formelles prévues aux $1^{\circ}$ à $6^{\circ}$ de l'article 229-3. Il s'assure également que le projet de convention n'a pas été signé avant l'expiration du délai de réflexion prévu à l'article 229-4.

Ce dépôt donne ses effets à la convention en lui conférant date certaine et force exécutoire". Al respecto, vid. P. HaMmJE, "Le divorce par consentement mutuel extrajudiciaire et le Droit international privé. Les aléas d'un divorce sans for", Rev. crit. DIP, 2017, $\mathrm{n}^{\mathrm{0}} 2$, p. 144 y ss.

${ }^{284}$ Nótese en tal sentido, G. KHairallah, "Aspects européens et internationaux du nouveau divorce par consentement mutuel”, en M.E. Ancel, L.D'Avout, J.C. Fernández Rozas et al (Eds.), Le droit à l'épreuve des siècles et des frontières. Mélanges en l'honneur du Professeur Bertrand Ancel, Paris/Madrid, LDGJ/ Iprolex, 2018, p. 965.

${ }^{285}$ Al respecto, S. Corneloup y T. KRUger, "Le Règlement 2019/1111”, cit., p. 237, no. 55 o E. DE Loth, "Bruxelles II ter: la refonte du règlement Bruxelles II bis vient d'être adoptée et publiée", La Quotidienne, 25.7.2019.

${ }^{286}$ A. BorCHÉ, "Circulation dans l'Union européenne des conventions de divorce par consentement mutuel conventionnel", AJ Famille, 2019, p. 60 y ss.

${ }^{287}$ Vid. P. HammJe, "Le divorce par consentement", cit., p. 152

${ }^{288}$ DRE n. $^{\circ}$ 238/2001, Série I-A de 13.10.2001.

${ }^{289}$ El precepto establece en su apartado 3 que en la Oficinal del Registro Civil se informará a los cónyuges que deseen divorciarse de mutuo acuerdo de la existencia de los servicios de mediación y que puede incluir un acuerdo sobre el ejercicio de la responsabilidad parental -"poder paternal"- que deberá ser enviado al Ministerio Fiscal competente para que se pronuncie (ap. 4). Si el Ministerio Fiscal entiende que en el acuerdo no se protegen suficientemente los intereses de los menores, puede solicitar su revisión o la presentación de uno nuevo (ap. 5). Por contra, si entiende que sí se defienden suficientemente los intereses de los menores, se decreta el divorcio y se inscriben los acuerdos relacionados con estos: por ejemplo, los apuntados en relación con el ejercicio de la responsabilidad parental.

${ }^{290}$ Art. 50.3: "An agreement confirmed by the Municipal Board of Social Welfare shall be enforceable like a final court order".
} 
109. Previsiblemente, pronto contaremos con algunas claves adicionales para evaluar la situación. El artículo 103 del Reglamento exige a los Estados comunicar antes del 31 de abril de 2021, cuales son los distintos órganos y autoridades a los que refieren los diversos preceptos del texto reglamentario, incorporándose las referencias en el portal de e-justice de la Unión. Ello debería ofrecer algunas claves sobre los acuerdos, al menos en materia de responsabilidad parental, a los que refiere el Reglamento ${ }^{291}$.

110. En todo caso, la solución recogida respecto de esta específica categoría de acuerdos plantea, al menos tres interrogantes, de naturaleza y trascendencia diversa, directamente vinculados entre sí.

1) En primer lugar, en relación con aquellos acuerdos que refieren exclusivamente a la responsabilidad parental y, más en concreto, a la sustracción del menor, se plantean dudas sobre su misma existencia y contenido, y sobre su aceptación en el plano comparado europeo. Y, por lo tanto, en torno a la virtualidad real de la solución adoptada en el Reglamento, atendida la existencia de unos intereses, los del menor, diferentes de los de los progenitores. $\mathrm{Y}$ al hecho adicional de que en muchos casos deberán de reconocerse y, en su caso ejecutarse, fuera de Europa dada la propia realidad del fenómeno de la sustracción internacional de menores. Lo que suscita, adicionalmente, la cuestión de la relación del Reglamento con otros textos convencionales como los Convenios de La Haya de 1980 y de $1996^{292}$.

2) En segundo lugar, y directamente vinculado a lo anterior, también está en liza la eficacia del eventual acuerdo alcanzado, dentro o fuera del marco de una mediación, en relación con la crisis matrimonial, en el que, adicionalmente, se aborden cuestiones de responsabilidad parental y sustracción de menores, entre otras muchas posibles; los conocidos como "package agreements" ${ }^{\prime 293}$. Una realidad habitual y sensible por la presencia de uno o varios menores ${ }^{294}$ y que plantea directamente la cuestión de su circulación ${ }^{295}$, que se ve, ahora, amparada y facilitada con la nueva regulación recogida en el Reglamento Bruselas II ter. Y para la que se establecen dos vías semejantes pero diferenciadas, al distinguirse entre los acuerdos concernientes a las crisis matrimoniales, recogidos en el artículo 65.1 del Reglamento, y las referentes a la responsabilidad parental, reguladas en el artículo 65.2 del texto, como forma de canalizar los efectos del compromiso alcanzado.

\footnotetext{
${ }^{291}$ Algunas, ciertamente, ya son previsibles. El caso francés, de nuevo, es clarificador. Vid. al respecto, Décret no ${ }^{\circ} 2016-1907$ du 28 décembre 2016 relatif au divorce prévu à l'article 229-1 du Code civil et à diverses dispositions en matière successorale, JORF $\mathrm{n}^{\circ}$ 302, de 29.12.2016.

${ }^{292}$ Una aproximación a esta problemática se encuentra en M. GonZÁlez MArimón, “El “diálogo” entre el TJUE y el TEDH en torno a la eliminación del exequátur del mecanismo de retorno del Reglamento Bruselas II bis", en J.M. MARTín RodRÍGUEZ y L. García-Álvarez (Dirs.), El mercado único en la Unión Europea. Balance y perspectivas jurídico-politicas, Madrid, Dykinson, 2019, p. 83 y ss.

${ }^{293} \mathrm{Al}$ respecto, M.C. ChÉLIz IngLÉs, "La ejecución de los acuerdos”, cit., pp. 43 y 46.

${ }^{294}$ Este carácter sensible se observa, por ejemplo, en el mencionado Cc francés. La posibilidad prevista en el art. 229-1 $\mathrm{Cc}$ se ve excepcionada por el propio texto en aquellas ocasiones en que existe un menor. Así, en primer lugar, el art. 229-2 Cc explicita que "Les époux ne peuvent consentir mutuellement à leur divorce par acte sous signature privée contresigné par avocats lorsque: $1^{\circ}$ Le mineur, informé par ses parents de son droit à être entendu par le juge dans les conditions prévues à l'article 388-1, demande son audition par le juge". Exigiendo el art. 229-3 Cc, so pena de nulidad, que el acuerdo de divorcio alcanzado por los cónyuges incorpore, entre otras exigencias de contenido, " $6{ }^{\circ}$ La mention que le mineur a été informé par ses parents de son droit à être entendu par le juge dans les conditions prévues à l'article 388-1 et qu'il ne souhaite pas faire usage de cette faculté." Algo que reitera, en sentido negativo, el art. 1144-2 CPC. Al respecto, vid. Circulaire du 26 janvier 2017 de présentation des dispositions en matière de divorce par consentement mutuel et de succession issues de la loi $n^{\circ} 2016-1547$ du 18 novembre 2016 de modernisation de la justice du XXIe siècle et du décret $n^{\circ} 2016-1907$ du 28 décembre 2016 relatif au divorce prévu à l'article 229-1 du code civil et à diverses dispositions en matière successorale (JUSC1638274C), BOMJ, ${ }^{\circ}$ 2017-06 de 30.6.2017, pp. 8 y 14-15 o J.-S. QUÉGUINER: “Le divorce sans juge”, cit., p. 2.

${ }^{295}$ En relación con la práctica del mencionado art. 229-1 Cc francés, se señala como la citada Circular de 26.1.2017 (vid. nota anterior) explicita que la eventual circulación quedará reputada del divorcio, y no así de los eventuales efectos sobre la responsabilidad parental que puedan incorporarse (vid. G. KHAIRAllaH, "Aspects européens et internationaux", cit., pp. 969970). De tal suerte que el notario francés "ne pourra pas délivrer le certificat visé à l'article 41 du règlement du 27 novembre 2003 et devra refuser toute requête en ce sens" (Circulaire du 26 janvier 2017, cit., p. 26).
} 
3) Por último -y éste es un tema ya apuntado, directamente vinculado con lo anterior- los acuerdos concluidos en el ámbito de las crisis matrimoniales que incorporen soluciones en materias no cubiertas por el Reglamento de 2019, o abordadas por otros Reglamentos en que no se prevea la circulación de este tipo de acuerdos, verán sometida -y generalmente limitada- su eficacia en lo referente a estas cuestiones, a lo dicho por éstos ${ }^{296} \mathrm{o}$, en su caso, por la legislación nacional. Así, por ejemplo, y en relación con el Reglamento sobre alimentos que no prevé específicamente la eficacia de este tipo de acuerdos ${ }^{297}$, la efectividad del compromiso concluido por las partes se verá directamente afectada; dado que, dependiendo de su contenido, el compromiso alcanzado circulará solo parcialmente en el seno de la UE.

\section{b) Reconocimiento y, en su caso, ejecución de acuerdos en materia de responsabilidad parental y sustracción internacional de menores}

111. A partir de la consolidación de estas tres categorías de títulos, el Reglamento articula diversos regímenes para su eficacia. Así, en primer lugar, y en relación específicamente con los acuerdos concluidos por las partes -en el marco de una mediación o de otro medio alternativo de resolución de controversias en materia de responsabilidad parental- que sean objeto de aprobación por "el órgano jurisdiccional después de haber examinado su fondo de conformidad con el Derecho y los procedimientos nacionales", el Considerando 14, deja claro que la eventual resolución judicial homologando el acuerdo "debe ser reconocid(a) o ejecutad(a) como una «resolución»" siguiendo las reglas recogidas en el Reglamento en relación con ellas.

112. Junto a ello, añade el Considerando 14, cualquier otro acuerdo "que adquiera efecto jurídico vinculante en el Estado miembro de origen tras la intervención formal de una autoridad pública o de otra autoridad comunicada por un Estado miembro a la Comisión para tal fin debe hacerse efectivo en los demás Estados miembros con arreglo a las disposiciones específicas del presente Reglamento sobre documentos públicos y acuerdos" ${ }^{298}$. En tal sentido, el artículo 64 del Reglamento Bruselas II ter avanza el diseño de un conjunto de normas comunes sobre el reconocimiento, y eventual ejecución, de los "documentos públicos que hayan sido formalizados o registrados, y ... los acuerdos que hayan sido registrados en un Estado miembro que ejerza su competencia con arreglo al capítulo II".

113. El régimen diseñado para los documentos públicos que hayan sido formalizados o registrados oficialmente como documentos públicos en cualquier Estado miembro, en materias comprendidas en el ámbito de aplicación del Reglamento ${ }^{299}$, es el mismo aplicable a la circulación de aquellos acuerdos que, sin ser documentos públicos, hayan sido firmados por las partes en materias que entran en el ámbito de aplicación del Reglamento ${ }^{300}$. Y que, adicionalmente, hayan sido registrados por una autoridad pública comunicada a la Comisión "en un Estado miembro que ejerza su competencia con arreglo al capítulo II" 301 del texto reglamentario, en el que se recogen las normas de competencia judicial internacional en materia matrimonial y de responsabilidad parental, y "tengan efecto jurídico vinculante y tengan fuerza ejecutiva en el Estado miembro de origen. Unos y otros -documentos públicos y acuerdos- se reconocerán y, en su caso, ejecutarán en otros Estados miembros sin que se requiera ninguna declaración de fuerza ejecutiva" ${ }^{302}$, esto es, sin necesidad de exequatur, en los términos y de acuerdo con las disposiciones del Reglamento.

\footnotetext{
${ }^{296}$ Al respecto, E. Gallant, "Le nouveau Règlement", cit., p. 3; Circulaire du 26 janvier 2017, cit., p. 26.

${ }^{297} \mathrm{Su}$ art. 2.3.b) incluye dentro de la categoría genérica de "documento público con fuerza ejecutiva" a "un acuerdo en materia de obligaciones de alimentos, celebrado ante las autoridades administrativas del Estado miembro de origen o formalizado por ellas".

${ }^{298}$ Considerando 14 Reglamento Bruselas II ter.

${ }^{299}$ De acuerdo con la descripción aportada por su art. 2.2.2.

${ }^{300}$ Vid. S. Corneloup y T. Kruger, "Le Règlement 2019/1111”, cit., p. 238.

${ }^{301}$ Art. 2.2.3 Reglamento Bruselas II ter.

${ }^{302}$ Art. 65.2 Reglamento Bruselas II ter.
} 
114. Focalizándonos exclusivamente en esta particular categoría de acuerdos prevista en el Reglamento, el artículo 66.5 del texto reglamentario da un paso significativo sobre el modelo diseñado en el Reglamento Bruselas II bis, y requiere la presentación del certificado ${ }^{303}$ regulado en los apartados $1 \mathrm{a}$ 4 de dicho precepto para sean reconocidos o ejecutados en otro Estado miembro.

115. En este sentido, y conectando precisamente con lo anterior, el artículo 66.1 del Reglamento Bruselas II ter especifica que, a instancia de una parte, el órgano jurisdiccional o la autoridad competente del Estado miembro de origen que en su día se comuniquen a la Comisión con base en el artículo 103 del Reglamento Bruselas II ter, "expedirán un certificado de documento público o acuerdo: ... b) en materia de responsabilidad parental, utilizando el formulario que figura en el anexo IX", rellenado en la lengua del acuerdo, o en cualquier otra lengua oficial de las instituciones de la UE solicitada por las partes ${ }^{304}$. En dicho certificado, y tal como añade el precepto, "constará un resumen de la obligación con fuerza ejecutiva que esté incluida en el documento público o acuerdo".

116. El certificado recogido en el Anexo IX -"relativo a un documento público o un acuerdo en materia de responsabilidad parental"- se expide a instancia de parte "únicamente si el Estado miembro que haya facultado a la autoridad pública u otra autoridad para registrar el acuerdo tenía competencia con arreglo al capítulo II, sección 2, del Reglamento", según se indica en el punto 2 del certificado y, además, el acuerdo tiene efecto jurídico vinculante en dicho Estado miembro, según se indica en los puntos 12.5 o $13.4^{305}$. No pudiendo emitirse, "si existen indicios de que el contenido del documento público o acuerdo es contrario al interés superior del menor" ${ }^{306}$.

117. El apartado 2 de este artículo 66 fija una serie de condiciones sin cuyo cumplimiento no cabe expedir el certificado. Hasta el punto de que, tal como prevé el artículo 67.2 del Reglamento, podrá ser revocado caso de no cumplirse. Se requiere, así, como destaca el propio certificado en su cabecera, que el Estado miembro que haya facultado a la autoridad pública o a otra autoridad para registrar el acuerdo concluido y firmado por las partes, sea competente con arreglo al capítulo II del Reglamento que contiene las normas de competencia judicial internacional. Y que, además, el acuerdo cuente con "efecto jurídico vinculante en dicho Estado miembro". En todo caso, se añade, no podrá producirse la expedición del certificado en materia de responsabilidad parental, apunta el apartado 3 del precepto, "si existen indicios de que el contenido del documento público o acuerdo es contrario al interés superior del menor".

118. El reconocimiento y, en su caso, ejecución del acuerdo concluido y firmado por las partes, y registrado por una autoridad pública comunicada a la Comisión por los Estados miembros de la UE en materia de responsabilidad parental, se presume al amparo del artículo 65.2 del Reglamento Bruselas II ter. En este sentido, el legislador europeo considera que todos aquellos acuerdos entre partes en materia de responsabilidad parental que cuenten con fuerza ejecutiva en un Estado miembro, y que, tal como precisa el artículo 65.2 "tengan efecto jurídico vinculante" para las partes, "deben asimilarse a «resoluciones» a efectos de la aplicación de las normas sobre reconocimiento y ejecución" recogidas en el texto reglamentario ${ }^{307}$. Y, en tal sentido, el reconocimiento y la eventual ejecución tan sólo "deberá denegarse" por parte de las autoridades del Estado miembro requerido -es por lo tanto una exigencia, no una simple posibilidad- cuando se den alguna de las circunstancias fijadas de forma exhaustiva por el artículo 68.2 del Reglamento.

\footnotetext{
${ }^{303}$ Un certificado ya previsto en los arts. 39 y 41 del Reglamento Bruselas II bis, con notables diferencias en su trascendencia entre uno y otro (Vid. P. HAMmJE, "Le divorce par consentement", cit., p. 152) que ahora, sin embargo, ve radicalmente incrementada su regulación y su trascendencia en el marco del régimen de eficacia extraterritorial de los documentos públicos y ciertos acuerdos diseñado en el Reglamento Bruselas II ter.

${ }^{304}$ Tal como afirma el art. 66.4 Reglamento Bruselas II ter. En relación con dicho certificado, nótese, igualmente, el art. 67, sobre rectificación o revocación.

${ }^{305}$ Tal como recoge el Anexo IX del Reglamento Bruselas II ter.

${ }^{306}$ Tal como recoge el Anexo IX del Reglamento Bruselas II ter.

${ }^{307}$ Considerando 70 del Reglamento Bruselas II ter.
} 
119. En concreto se trata de las siguientes causas:

1) Si su reconocimiento fuere manifiestamente contrario al orden público del Estado miembro en el que se invoca tal reconocimiento, "teniendo en cuenta el interés superior del menor"308; o

2) A petición de cualquier persona que alegue que el documento público o el acuerdo infringe su responsabilidad parental, "si el documento público se hubiere formalizado o registrado, o el acuerdo se hubiere celebrado y registrado, sin la participación de dicha persona"309; o

3) En el caso de que fuere irreconciliable, y en la medida en que lo fuere, con una resolución, un documento público o un acuerdo posterior en materia de responsabilidad parental dictado en el Estado miembro en el que se invoca el reconocimiento o se solicita la ejecución ${ }^{310}$; o

4) Si fuere irreconciliable, y en la medida en que lo fuere, con una resolución, un documento público o un acuerdo posterior en materia de responsabilidad parental dictado en otro Estado miembro o en el Estado no miembro de residencia habitual del menor, "siempre y cuando la resolución, el documento público o el acuerdo posterior reúna las condiciones necesarias para su reconocimiento en el Estado miembro en que se invoca el reconocimiento o se solicita la ejecución" ${ }^{311}$. Lo que, en última instancia, supone atribuir de forma indirecta efectos en la UE a un acuerdo alcanzado fuera de las fronteras de la Unión.

120. Adicionalmente, añade el artículo 68.3 del Reglamento, el reconocimiento o la ejecución de un acuerdo en materia de responsabilidad parental "podrá denegarse... si ... el acuerdo se hubiere registrado, sin haber dado al menor capaz de formarse sus propios juicios la posibilidad de expresar su opinión". Una exigencia, didáctica, enunciada en términos potenciales que, sin embargo, presenta matices y contradicciones interesantes en cuanto a su funcionamiento, a la vez que plantea de lleno la cuestión del compromiso del Reglamento Bruselas II ter con la audiencia del menor. Precisamente, uno de los elementos más destacados del texto de $2019^{312}$.

\section{d) La audiencia del menor como novedad del Reglamento Bruselas II ter y su salvaguarda en re- lación con la eficacia de los acuerdos alcanzados por las partes en relación con la responsabilidad parental y la sustracción de menores}

121. El Reglamento Bruselas II ter supone un paso adelante en relación con la aceptación del derecho del menor a ser escuchado en todos los procesos y actuaciones administrativas que le conciernen, respecto del texto de Bruselas II bis, en el que esta posibilidad no siempre aparecía suficiente nítida ${ }^{313}$. Ahora, el artículo 21 del Reglamento explicita de forma clara e individualizada, el "Derecho del menor a expresar sus opiniones", señalando en tal sentido, en su apartado 1, que los órganos jurisdiccionales competentes de los Estados miembros, "de conformidad con la legislación y el procedimiento nacionales, darán a los menores que tengan capacidad para formarse sus propios juicios la posibilidad real y efectiva de expresar libremente sus opiniones, bien directamente bien a través de un representante o un organismo apropiado". Añadiendo en el apartado 2 que, cuando el órgano jurisdiccional, "de conformidad con la legislación y el procedimiento nacionales, dé al menor la oportunidad de expresar sus opiniones de acuerdo con el presente artículo, prestará la debida importancia a las opiniones del menor de acuerdo con su edad y madurez."

\footnotetext{
${ }^{308}$ Art. 68.2.a) Reglamento Bruselas II ter.

${ }^{309}$ Art. 68.2.b) Reglamento Bruselas II ter.

310 Art. 68.2.c) Reglamento Bruselas II ter.

${ }^{311}$ Art. 68.2.a) Reglamento Bruselas II ter.

${ }^{312} \mathrm{Al}$ respecto S. CORNeloup y T. KRUGer, “Le Règlement 2019/1111”, cit., pp. 227-228.

${ }^{313}$ El Considerando 19 del texto de 2003 destacaba el importante papel desempeñado por la audiencia del menor "en la aplicación del presente Reglamento, sin que éste tenga por objeto modificar los procedimientos nacionales aplicables en la materia" y esta exigencia venía recogida en diversos preceptos -arts. 11.2 y 5, 23.b), 41.2.b) y c) y 42.2.a) y b)-. Al respecto, vid. Th. Kruger y L. Samyn, "Brussels II bis: successes and suggested improvements", Journal of Private International Law, vol. 12-1, 2016, pp. 156-158. Igualmente, COMISIÓN EuropeA, Guía práctica para la aplicación del Reglamento Bruselas II bis, Bruselas, Unión Europea, 2014, pp. 76-80.
} 
122. Una posición acorde con lo señalado por la mencionada Observación General n ${ }^{\circ}$. 14, en el sentido de que los "Tribunales" -incluyéndose bajo esta denominación al arbitraje, la conciliación y la mediación- "deben velar por que el interés superior del niño se tenga en cuenta en todas las situaciones y decisiones, de procedimiento o sustantivas, y han de demostrar que así lo han hecho efectivamente"

123. En línea con ello, el artículo 26 del Reglamento recoge, igualmente, el "Derecho del menor a expresar su opinión en los procedimientos de restitución". Señalando el párrafo 2 del precepto que el mencionado artículo 21 del texto de 2019 será, igualmente, de aplicación "a los procedimientos de restitución con arreglo al Convenio de La Haya de 1980.”

124. El mandato del artículo 68.3 del Reglamento, en relación con la posibilidad de denegar el reconocimiento o la ejecución de un acuerdo en materia de responsabilidad parental si "el acuerdo se hubiere registrado, sin haber dado al menor capaz de formarse sus propios juicios la posibilidad de expresar su opinión" debe aproximarse a partir de la decisión del legislador europeo de "aclara(r) el derecho del menor a que se le brinde ocasión de expresar su opinión en los procedimientos que le afecten"315

125. Sin embargo esta posibilidad de denegar el reconocimiento, y, en su caso, la ejecución del acuerdo, por no haber asegurado al menor que cuenta con un suficiente grado de madurez la capacidad de expresar sus opiniones, contrasta severamente con el mandato claramente facultativo que recoge el Considerando 39 del propio Reglamento en relación con este punto. El Considerando afirma de forma explícita que "aunque la audición del menor es un derecho de este, no debe constituir una obligación absoluta, sino que debe evaluarse teniendo en cuenta su interés superior, por ejemplo, en los casos que lleven aparejados acuerdos entre las partes".

126. Más aún, en contraste con el fomento de la audiencia del menor que realiza el Reglamento Bruselas II ter, el Considerando 71 afirma de manera un tanto críptica que "Aunque la obligación de dar al menor la oportunidad de expresar su opinión con arreglo al presente Reglamento no debe aplicarse a los documentos públicos y los acuerdos, el derecho del menor a expresar su opinión sigue siendo de aplicación de conformidad con el artículo 24 de la Carta y a la luz del artículo 12 de la Convención de las Naciones Unidas sobre los Derechos del Niño conforme a su aplicación con arreglo a la legislación y el procedimiento nacionales". Y su ausencia, añade, "no debe constituir automáticamente un motivo de denegación del reconocimiento y la ejecución de documentos públicos y acuerdos en materia de responsabilidad parental".

127. En el supuesto concreto de España, este obligatorio protagonismo atribuido al órgano jurisdiccional contrasta con el tenor del artículo 778 quinquies.12) LEC, relativo al procedimiento de restitución o retorno de menores en los supuestos de sustracción internacional, en el que no se habla de obligación sino de la mera posibilidad de que en "cualquier momento del proceso, ambas partes" puedan solicitar la suspensión de éste para someterse a mediación. A la vez que se admite que también el "Juez podrá en cualquier momento, de oficio o a petición de cualquiera de las partes, proponer una solución de mediación" si estima posible que puedan llegar a un acuerdo y, siempre, "sin que ello deba suponer un retraso injustificado del proceso" e intentando que la duración de la mediación sea lo más breve posible y concentrada en el mínimo número de sesiones ${ }^{316}$. Se trata, en suma, como apunta la SAP de Barcelona de 15 de septiembre de $2014^{317}$, de recomendarles que, "si, pese a intentar llegar a otros acuerdos, ... no lograran coincidencias en la forma de dirimir las diferencias, acudan a un mediador o a una entidad mediadora, ... pues lo único que se consigue con una actitud beligerante, acudiendo reiteradamente a los Tribunales para dirimir sus controversias, es perturbar la tranquilidad de las menores, tan necesaria para su correcto y sano desarrollo integral".

\footnotetext{
${ }^{314}$ Comité de los DeReChos del NIÑo, Observación general no $n^{\circ}$, cit., p. 9, no 29.

${ }^{315}$ Considerando 2 del Reglamento Bruselas II ter.

${ }^{316}$ En relación con la práctica del modelo, vid. A. García Herrera, "Reestructuración de la familia", cit., pp. 10-11.

${ }^{317} \mathrm{~N}^{\mathrm{o}}$ 596/2014, FD ${ }^{\circ}$ Segundo, TOL 4.538.290.
} 
128. El Considerando 71 refiere al acuerdo, en el sentido que se le atribuye en el artículo 2.2.3 del Reglamento, alcanzado en el marco de una mediación o fuera de ella, que recoge lo acordado por las partes. La referencia a la audiencia del menor, como manifestación de la consideración primordial del interés superior en todos los procesos que le afectan, pareciera centrarse, tanto en la conclusión misma del acuerdo por las partes ${ }^{318}$, como en la autorización por la autoridad, en línea con lo señalado por la mencionada Observación General n ${ }^{\circ} .14$ del Comité de los derechos del niño que refiere esta exigencia, también, "a los procesos de conciliación, mediación y arbitraje" 319 en cuanto el niño puede verse afectado por ellas, y lo pactado puede contar "con repercusiones importantes" en su vida y desarrollo ${ }^{320}$.

129. En tal sentido, el propio certificado relativo a un documento público o un acuerdo en materia de responsabilidad parental emitido al amparo del artículo 66.1.b) de éste, y que viene recogido en el Anexo IX del Reglamento Bruselas II ter, incorpora un apartado 10, en el que se informa del hecho de si el menor o los menores a los que se refiere el documento público o acuerdo -indicados en el punto 6 del certificado- han sido efectivamente capaces de formarse su propio juicio. Requiriendo, en tal caso, información -apartado 11- sobre si se ha dado al menor o menores capaces de formarse su propio juicio "la posibilidad real y efectiva de expresar su opinión".

\section{Qué será, será (Whatever will be, will be)}

130. El Reglamento Bruselas II ter supone un paso más en el proceso del fomento de la mediación y de otros medios de resolución alternativa de conflictos en el seno de la UE, siendo este mismo hecho uno de los elementos emblemáticos del texto de 2019. A partir de este dato positivo, sin embargo, el Reglamento plantea una serie de cuestiones, tanto en relación con las soluciones diseñadas, como con respecto a su propia filosofía y anclaje en el modelo europeo de DIPr.

131. En relación con las primeras, si bien en cuanto a su contenido, las soluciones recogidas en el Reglamento incorporan un tratamiento innovador, y positivo, respecto la circulación en el seno de la Unión de ciertos acuerdos. La consolidación de una categoría autónoma de "acuerdo" en el Reglamento, independiente de los documentos públicos, pero que comparte con éstos el modelo de reconocimiento y ejecución diseñado, suscita directamente la cuestión de su concreción y entendimiento. Generando, igualmente, dudas sobre su virtualidad y proyección práctica, máxime cuando la práctica refleja la habitual existencia de "package agreements", en un ámbito temático tan complejo como es el de la responsabilidad parental y, especialmente, el del secuestro de menores. Habrá que esperar al futuro para ver cómo evoluciona la práctica del modelo, y evaluar hasta qué punto las reglas diseñadas se convierten en un acicate o en una rémora para el fomento de los MASC en este sector.

132. Junto a ello, la ampliación de la potencial circulación a ciertos acuerdos, en general, y no, estrictamente, a los alcanzados en el marco de un procedimiento de mediación, además de suponer un intento de superar, en línea con lo acontecido en otros foros internacionales, las limitaciones intrínsecas de la institución -recordemos, anclada en la imprescindible participación de un mediador-. Soslayando la cuestión -de base- de justificar cuáles son las diferencias existentes, en lo relativo a su naturaleza, entre un acuerdo obtenido por las partes sin asistencia, o con asistencia, de un tercero ${ }^{321}$. Supone, igualmente un desbordamiento del propio marco normativo europeo, limitado a la regulación de la mediación.

133. En todo caso, y más allá de lo anterior, el Reglamento permite ciertas reflexiones adicionales. Desde un punto de vista teórico, se asiste a un paso adicional en el proceso de alteración del

\footnotetext{
${ }^{318}$ Algo en lo que incide la doctrina europea, al respecto, I. Pretelli, "Child Abduction and Return", cit., p. 14.

319 Comité de los DeREChOS DEL NIÑo, Observación general $n^{\circ} 14$, cit., p. 8, n ${ }^{\circ} .27$.

${ }^{320}$ COMITÉ DE LOS DERECHOS DEL NIÑO, Observación general $n^{\circ} 14$, cit., p. 9, nº. 29.

${ }^{321}$ C. Esplugues Mota, "La Convención de Singapur de 2018”, cit., p. 64.
} 
equilibrio interno del Derecho internacional privado, primando la dimensión de competencia judicial internacional y de reconocimiento y ejecución -el tradicional conflicto de jurisdicciones- frente al de la determinación del derecho aplicable -el conflicto de leyes ${ }^{322}$. A la vez que, desde una perspectiva de sistema, se produce una profundización en la disgregación de la respuesta aportada, plasmada en la consolidación de una pluralidad de soluciones dependiendo del instrumento al que se pretenda dotar de eficacia en la Unión y de la materia concreta cubierta por éste ${ }^{323}$.

${ }^{322}$ S. Corneloup y T. Kruger: "Le Règlement 2019/1111”, cit., pp. 237-238.

${ }^{323}$ El ejemplo del régimen aplicable a los "documentos públicos", categoría clásica recogida en los distintos textos europeos, es paradigmático al respecto. Vid. J.L. Iglesias Buhigues: "Luces y sombras de la cooperación judicial en materia civil en la UE”, en J. Forner Delaygua, C. GonzÁlez Beilfuss y R. Viñas Farré (Eds.), Entre Bruselas y La Haya. Estudios sobre la unificación internacional y regional del Derecho internacional privado, Madrid, Marcial Pons, 2013, p. 550. 